\title{
Investigação do potencial de desenvolvimento do preconceito em crianças pequenas
}

(versão corrigida)

Tese apresentada ao Instituto de Psicologia da Universidade de São Paulo, como parte dos requisitos para obtenção do grau de Doutor em Psicologia.

Área de concentração: Psicologia Escolar e do Desenvolvimento Humano.

Orientador: Prof. Livre-docente José Leon Crochík.

São Paulo

2016 


\title{
AUTORIZO A REPRODUÇÃO E DIVULGAÇÃO TOTAL OU PARCIAL DESTE TRABALHO, POR QUALQUER MEIO CONVENCIONAL OU ELETRÔNICO, PARA FINS DE ESTUDO E PESQUISA, DESDE QUE CITADA A FONTE.
}

\author{
Catalogação na publicação \\ Biblioteca Dante Moreira Leite \\ Instituto de Psicologia da Universidade de São Paulo
}

Cabral, Fernanda Araujo.

Investigação do potencial de desenvolvimento do preconceito em crianças pequenas / Fernanda Araujo Cabral; orientador José Leon Crochík. -- São Paulo, 2016.

$139 \mathrm{f}$.

Tese (Doutorado - Programa de Pós-Graduação em Psicologia. Área de Concentração: Psicologia da Aprendizagem, do Desenvolvimento e da Personalidade) - Instituto de Psicologia da Universidade de São Paulo.

1. Preconceito 2. Desenvolvimento humano 3. Escala F 4. Teoria crítica da sociedade I. Título. 
Nome: Cabral, Fernanda Araujo

Título: Investigação do potencial de desenvolvimento do preconceito em crianças pequenas.

Tese apresentada ao Instituto de Psicologia da Universidade de São Paulo para obtenção do título de Doutor em Psicologia.

Aprovado em:

Banca Examinadora

Prof. Dr.

Instituição: Assinatura:

Prof. Dr.

Instituição: Assinatura:

Prof. Dr.

Instituição: Assinatura:

Prof. Dr.

Instituição: Assinatura:

Prof. Dr. Instituição: Assinatura: 
Para Caio, meu parceiro na busca de um mundo onde nosso Leozinho possa entender que:

O mundo só vai prestar para nele se viver no dia em que a gente ver um gato maltês casar com uma alegre andorinha saindo os dois a voar o noivo e sua noivinha dom gato e dona andorinha (Trova de Estevão da Escuna em O Gato Malhado e a Andorinha Sinhá ) 


\section{AGRADECIMENTOS}

Ao meu orientador Prof. José Leon Crochík, pelos ensinamentos e direcionamento nessa pesquisa e nos caminhos do conhecimento da Teoria Crítica da Sociedade.

Aos professores Dr. José Geraldo Silveira Bueno e Dr. Lineu Norió Kohatsu, pelas preciosas contribuições na banca de qualificação.

A todos os professores que fizeram parte desta jornada de conhecimento, em especial ao prof. Dr. Odair Sass que me apresentou a Teoria Crítica da Sociedade e aos professores Dr. Carlos Antonio Giovinazzo Junior, Dr. Luis Guilherme GaleãoSilva e Dr. Pedro Fernando da Silva, que me auxiliaram na compreensão e aprofundamento desta teoria.

À escola que me acolheu para a realização da pesquisa, aos pais que consentiram a participação de seus filhos e às crianças que deram todo sentido a esse estudo.

A minha tia Vanilde, pela confecção dos bonecos utilizados na pesquisa.

Ao Caio, Doug, Duda e Lupita pelo companheirismo e incentivo na escrita.

Ao meu irmão André por sempre acreditar e incentivar, e por ter tornado minha jornada acadêmica possível de ser realizada até aqui.

À minha irmã Cristina pelo exemplo e aos meus pais por nos trazerem até aqui.

Ao meu sobrinho Lucas pela sua preciosa ajuda na compreensão dos dados estatísticos e à minha sobrinha Luiza por seu apoio nesses momentos.

Aos amigos e incentivadores de sempre, especialmente à Fernanda Borsatto e Amélia Zampronha, Samantha Mesojedovas e Jaimé Cará. 


\section{RESUMO}

Cabral, F.A. (2016). Investigação do potencial de desenvolvimento do preconceito em crianças pequenas. Tese de Doutorado, Instituto de Psicologia, Universidade de São Paulo, São Paulo.

Esta pesquisa foi realizada com o objetivo de investigar como crianças com idade entre três e quatro anos reagem a situações cotidianas, durante o brincar, apresentando manifestações potencialmente preconceituosas. Para tanto se propôs adaptar a escala do fascismo (escala F) para situações que representam o cotidiano de forma lúdica, o que permitiu identificar elementos que denotam o preconceito já em crianças. A pesquisa foi realizada em uma escola da rede privada de ensino do município de São Paulo, com crianças de idades entre três e quatro anos, com as quais o pesquisador realizou um momento de observação lúdica no qual as crianças interagiram livremente com bonecos que representavam diferenças entre cor de pele e de presença ou ausência de deficiência, e um momento de aplicação de situações problema representadas de forma lúdica e que tiveram a intenção de avaliar os aspectos investigados na escala $F$. Os sujeitos da pesquisa também estiveram divididos em agrupamentos de crianças que estudavam com crianças com deficiência em sala de aula e agrupamentos que não estudavam, com o objetivo de identificar possíveis diferenças no padrão de respostas dada a relação com a inclusão da criança com deficiência no ambiente escolar. Os resultados avaliados a partir do referencial da Teoria Crítica da Sociedade apontaram para a uma baixa pontuação numa escala de manifestação de atitudes que denotam o preconceito em crianças com idade entre três e quatro anos e pode-se concluir que essa idade é um momento propicio para se aplicar intervenções com vistas a minimizar os efeitos do preconceito, embora indique a continuidade de pesquisas sobre a formação do preconceito que incluam o elemento lúdico em crianças desta faixa etária.

Palavras chave: preconceito - desenvolvimento humano - escala F - Teoria Crítica da Sociedade. 


\begin{abstract}
Cabral, F.A. (2016). Investigation on the potential development of prejudice on small children. Thesis, Instituto de Psicologia, Universidade de São Paulo, São Paulo.

This research aims at investigating how three- and four-year-old children react to everyday situations, during play time, showing potentially prejudiced behavior. We propose adapting the fascist scale (F-scale) to everyday situations represented in a ludic way, which allowed us to identify prejudiced elements in children. This research was developed in a private school in São Paulo, with three- and four-year-old children. During the study, the researcher observed the children as they played with dolls (which could have different skin tones, presence or absence of malformation) and as they were presented with problematic situations in order to be analyzed based on the F-scale. The subjects of the research were also divided into two groups - those who had classmates with special needs and those who did not. Our objective was to identify possible differences in the response pattern regarding the inclusion of children with special needs in the classroom environment. The results were analyzed based on the Critical Social Theory, pointed to a low score on a manifestation scale of attitudes that denotes prejudice in three- to four-year-old children. We might conclude that, at this age, it is a favorable moment to intervene aiming at lessening prejudice effects. Moreover, it also indicates that research on prejudice formation along with ludic elements should continue to be done with children of that age.
\end{abstract}

Key words: prejudice, human development, F-scale, Critical Social Theory. 


\section{LISTA DE QUADROS}

Quadro I - forma de proposição da representação lúdica para os sujeitos da pesquisa. 74

Quadro II - relação entre itens medidos pela escala F e elaboração de situações problema da representação lúdica.

Quadro III- tabulação da avaliação dos juízes sobre as situações problema propostas na representação lúdica e o índice que correspondem na escala $F$ 79

Quadro IV - relação final entre itens medidos pela escala $F$ e elaboração de situações problema da representação lúdica. 80

Quadro V: resultados obtidos no pré-teste. .81

Quadro Vl: escala de pontuação para respostas a situações problema propostas na representação lúdica. 83

Quadro VII: escala de pontuação para respostas a situações problema propostas na representação lúdica. 86

Quadro VIII: escala final de pontuação para respostas a situações problema propostas na representação lúdica. 91

\section{LISTA DE TABELAS}

Tabela I: resultados medianas, Kruskall-Wallys e U de Mann-Withney calculados para a pontuação total obtida por criança. 102 


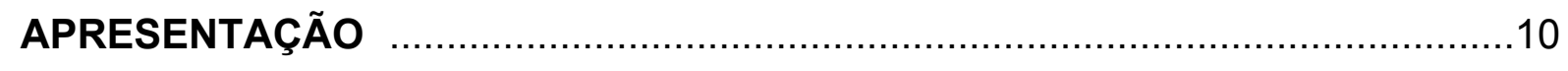

1. ESTUDO SOBRE A PERSONALIDADE AUTORITÁRIA .................................14

2.PRECONCEITO

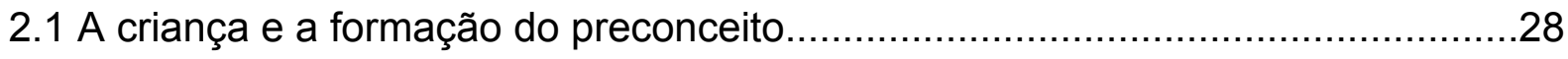

2.2 Revisão bibliográfica sobre o preconceito..................................................... 49

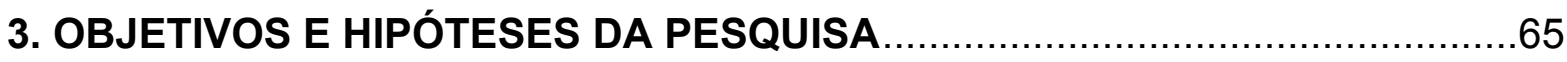

4. MÉTODO

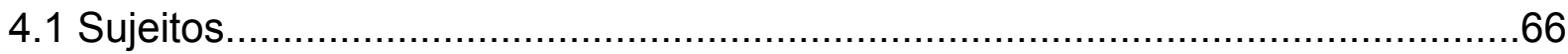

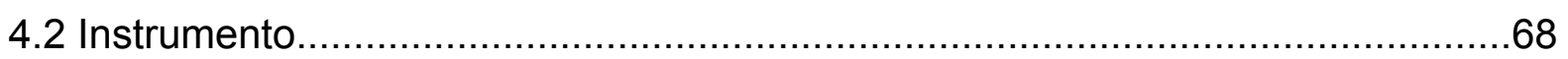

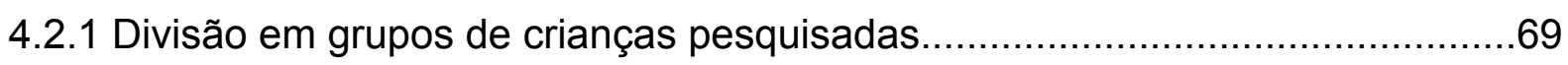

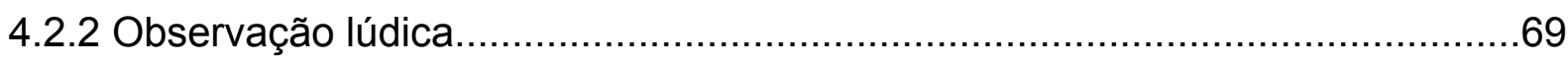

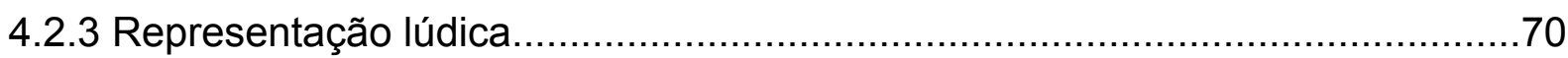

5. APRESENTAÇÃO E DISCUSSÃO DOS RESULTADOS

5.1 Apresentação e discussão dos resultados obtidos na observação lúdica............94

5.2 Apresentação e discussão dos resultados obtidos na representação lúdica.......97

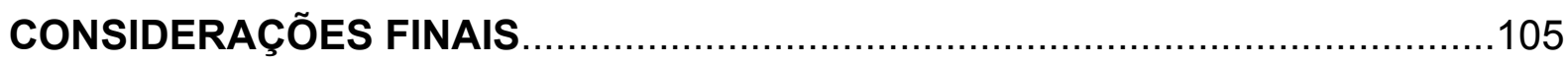

REFERÊNCIAS

APÊNDICES 


\section{Apresentação}

Junto às respostas obtidas com o término da dissertação de mestrado, uma questão se impôs abrindo horizontes para uma nova pesquisa: crianças de pouca idade já possuem relações em que demonstram preconceito? O estudo realizado na dissertação teve como sujeitos de pesquisa crianças com idade entre nove e 11 anos, matriculadas em uma escola municipal de ensino fundamental da cidade de São Paulo e a pergunta da pesquisa era como se davam as relações sociais entre crianças com e sem deficiência na sala de aula do ensino regular. Para a faixa etária pesquisada já foi constatado que, embora as crianças frequentassem a mesma sala de aula e mantivessem contato físico e verbal, não ocorria relação social de igualdade entre as crianças com e sem deficiência, sendo que os alunos com deficiência não foram citados como preteridos ou preferidos na elaboração do sociograma ${ }^{1}$ das relações estabelecidas em sala de aula e eles também não citaram os alunos sem deficiência da sala de aula em seus sociogramas. (Cabral, 2011) Este resultado mostra a exclusão social dessas crianças com base nas respostas obtidas para a elaboração dos sociogramas, o que já seria uma forma de manifestação do preconceito na criança. Essa reação de negação da possibilidade de se relacionar com o outro que é diferente chama a atenção, pois o esperado era que as crianças, quando tivessem a possibilidade de constituir experiência com outra criança que lhe é diferente, pudessem ampliar e modificar os conceitos pré-estabelecidos que lhe foram transmitidos.

Martins (1997) explica que o conceito de exclusão só é possível para indivíduos que não são mais comentados ou mesmo lembrados por nenhum membro da sociedade, dando a ideia de que todos estão incluídos, mesmo que de forma precária, enfatizando as relações entre dominante e dominado. Utiliza, então, o conceito de inclusão marginal, no qual determinados grupos são colocados à margem da sociedade, como forma de reforçar a posição social daqueles que são dominantes. Confrontando o resultado obtido na elaboração dos sociogramas com a análise de Martins, chega-se à preocupante conclusão de que as crianças com deficiência são colocadas à margem pela maior parte do grupo de pares no qual estão inseridas, pois mesmo estando presentes fisicamente no grupo de alunos da sala de aula, não são percebidas pelo grupo de pares já que não constituem

\footnotetext{
${ }^{1}$ Teste realizado para identificar as preferencias e rejeições durante a formação de grupos.
} 
relações seja de raiva ou de amizade, o que as tornam metaforicamente invisíveis. Existe outra parcela dos alunos que consegue reconhecer a participação da criança com deficiência dentro do grupo de alunos, mas as identifica em situação de marginalização perante o grupo.

Porém algumas crianças, ou mesmo algumas situações em que as crianças apresentam elementos de resistência à formação preconceituosa, também foram identificadas na referida pesquisa de Cabral (2011) com tentativas do estabelecimento de relação social entre crianças com e sem deficiência, sobretudo nos momentos de observação na sala de aula em que não houve a mediação do adulto. Sendo assim, apesar de as crianças buscarem se relacionar e se identificar com outras que Ihes são diferentes, a mediação do adulto atua como um dos elementos que impedem a relação. Enfatizando esse aspecto, os resultados obtidos na pesquisa vem ao encontro das discussões sobre preconceito, segundo Crochík (2006), mostrando que o preconceito não é inato e sim transmitido culturalmente.

Na mesma época em que foi elaborada a pesquisa supra citada, Crochík et al (2013) realizaram um estudo com objetivos similares, porém comparando dados de preferência e rejeição a partir da construção de uma escala de proximidade que tem como base a utilização do teste sociométrico. Os sujeitos da pesquisa foram crianças que estudavam em salas de aula onde havia alunos em situação de inclusão, sendo um grupo pertencente à escola pública e outro à escola particular, ambas situadas no município de São Paulo. A faixa etária dos sujeitos aproximavase da selecionada na pesquisa de Cabral: crianças entre 10 e 11 anos. Nos resultados obtidos, as crianças com deficiência foram citadas durante o teste sociométrico, porém após o tratamento dos dados a conclusão dos pesquisadores indicou que um dos indivíduos em situação de inclusão na escola particular pôde ser considerado rejeitado e os demais indivíduos em situação de inclusão, tanto na escola pública quanto na escola particular, puderam ser considerados negligenciados pelo grupo de pares ou tinham igual grau de rejeição e aceitação. Os autores ainda analisaram que existia um processo de exclusão dos indivíduos tidos como diferentes, mesmo ante o processo de inclusão escolar, e justificaram confirmando a hipótese de que a educação é marcada por uma racionalidade que valoriza a competição entre os alunos, objetivando atingir um ideal de produtividade. Os autores não deixam de enfatizar que a inclusão se faz necessária e já é um 
avanço no caminho para diminuir os efeitos do preconceito nas relações humanas, porém necessita ser a cada dia aprimorada.

Há também outras pesquisas que investigaram as relações estabelecidas entre crianças com e sem deficiência, como Batista e Enumo (2004), que aplicaram o teste sociométrico e filmagens em três salas de aula do primeiro ciclo do ensino fundamental, o que hoje corresponde ao segundo e terceiro ano do fundamental, que tinham crianças com deficiência entre seus alunos. Obtiveram como resultado do teste sociométrico que as crianças com deficiência são mais rejeitadas que seus companheiros de sala que não possuem a deficiência. Apesar dos dados do teste sociométrico apontarem para a não integração dos alunos com deficiência intelectual, houve uma exceção entre um dos sujeitos positivos, que obteve dados de aceitação no teste sociométrico. A hipótese para essa exceção é de que o aluno já havia estudado com seus companheiros de sala em anos anteriores. Nas filmagens que realizaram para complementar a pesquisa, observaram a pouca interação entre as crianças com e sem deficiência, de forma que estes permaneciam mais distantes do grupo de alunos e que as interações entre os alunos com e sem deficiência tinham um caráter mais didático, mesmo com o aluno que obteve aceitação no teste sociométrico.

Estas pesquisas evidenciam a dificuldade de estabelecer o contato entre as crianças com e sem deficiência, bem como as barreiras para a identificação com o diferente. Também destaca-se que as pesquisas foram realizadas com crianças ainda no ensino fundamental, e já se observou a manifestação de atitudes de preconceito e negação da experiência nas relações estabelecidas entre as crianças. Sendo assim, qual seria a idade em que as crianças são capazes de se relacionar com outras, de forma a constituir experiência com o outro que lhe é diferente?

Tal pergunta remete à questão que direciona os estudos produzidos por Adorno et al (1965) em a Personalidade Autoritária, que intencionou responder porque pessoas consideradas "de bem" aderiram ao fascismo, mesmo contra seus interesses racionais. Analogamente, o objetivo geral desta pesquisa é compreender se as características da personalidade autoritária podem ser notadas já desde a primeira infância, buscando como sujeito de pesquisa crianças entre três e quatro anos, idade que a psicanálise delineia como o início da fase de formação do super eu, ou seja, como a fase da internalização das regras sociais (Freud, 1905). Tal como na pesquisa sobre a personalidade autoritária, na qual a intenção foi investigar 
o potencial de adesão ao fascismo com vistas a aumentar o potencial de resistência dos indivíduos ante o preconceito, o intuito desta pesquisa se faz em compreender como crianças de pouca idade reagem e desenvolvem o preconceito, dando continuidade os achados de Cabral (2011) e Crochík et all (2013) nos quais se percebe que as crianças, conforme o esperado para a idade, estão propensas a participar das relações constituindo experiências com o outro que lhes é diferente, mas também apresentam preconceito, negando as relações com o diferente quando estas Ihes são perguntadas em forma de questões sobre a possibilidade de estabelecer relacionamentos sociais.

A justificativa desta pesquisa se baseia no texto de Adorno (2006), principalmente em sua afirmação de que é necessário educar a criança desde a mais tenra idade como forma de evitar a barbárie ocorrida em Auschwitz, ou seja, como uma tentativa de impedir a disseminação da frieza nas relações e a formação do preconceito. Como assinalado antes, se o preconceito não é inato e sim constituído a partir das relações sociais que o sujeito estabelece, faz-se necessário investigar as origens das manifestações do preconceito, com a finalidade de favorecer a abertura para a experiência, já desde a primeira infância.

Esta pesquisa se propõe a investigar a existência e as formas de manifestação do preconceito em crianças na primeira infância, utilizando para tanto o referencial da Teoria Crítica da Sociedade, com base nas obras de Adorno, Benjamin, Horkheimer e Marcuse. Para tanto, esta tese está organizada de forma que após esta breve apresentação, segue uma revisão sobre os pontos que enfocam os aspectos da infância na obra "A personalidade Autoritária" escrita por Adorno et al. (1965) que busca traçar correlações entre esse estudo e a sociedade, uma introdução sobre o preconceito que contém um capítulo sobre o preconceito e as suas influências no desenvolvimento da personalidade na criança e uma revisão bibliográfica sobre as pesquisas relacionadas ao preconceito. Os objetivos e a hipótese da pesquisa foram discutidos a partir da proposta da pesquisa de campo, apresentada e analisada na segunda parte da tese. Por fim, segue-se a apresentação dos resultados da pesquisa de campo e as considerações finais obtidas como resultado desta pesquisa. 


\section{Estudo sobre a personalidade autoritária}

A obra "A personalidade autoritária" escrita por Adorno, Brunswik, Levinson e Sanford (1965) teve como principal preocupação estudar o indivíduo potencialmente fascista, ou seja, aquele que, apesar de não possuir ideias tipicamente fascistas, aderiu com facilidade à propaganda fascista. Ao pensar em como a criança pequena pode se tornar um adulto reprodutor ou mesmo gerador de preconceitos, é possível estabelecer um paralelo com os objetivos desta pesquisa, tendo em vista que a criança também não é em si um sujeito preconceituoso e que o sujeito não nasce preconceituoso, mas é criado em um ambiente que já reproduz as condições para o preconceito, sendo assim, faz-se importante investigar como a criança absorve tais informações e como irá reproduzir ou não o preconceito. Na pesquisa sobre a personalidade autoritária foi estabelecida uma escala que se propôs medir o potencial do indivíduo para adesão ao preconceito, denominada escala do Fascismo, conhecida como Escala F. Esta pesquisa se propôs a adaptar a escala F, criando parâmetros para observar o quanto o brincar da criança já é carregado de atitudes preconceituosas, investigando o potencial para aderir ou para resistir aos elementos que levam ao preconceito. Portanto, faz se aqui necessário uma breve revisão sobre as bases teóricas que levaram à construção da escala F. Para tanto segue uma discussão sobre alguns dos capítulos da obra que mais se aproximam com o tema dessa pesquisa, de forma que foram selecionados primeiramente dois capítulos que explicam como se constituiu a produção da escala $F$, que são: Introdução (I), Medição das tendências antidemocráticas implícitas (VII). E também capítulos que representam estudos importantes para estabelecermos correlações com os achados desta pesquisa, representados por: Os pais e a infância a partir das entrevistas $(X)$, Organização cognitiva e dinâmica da personalidade através das entrevistas (XII) e O preconceito através das entrevistas (XVI).

A hipótese principal da pesquisa de Adorno, Brunswik, Levinson e Sanford (1965) era a de que as convicções políticas, econômicas e sociais de um indivíduo estão unidas por uma mesma forma de raciocínio e, juntas, expressam as tendências da personalidade do indivíduo. Sendo assim, não se faria necessário direcionar os estudos apenas para os indivíduos que se declararam fascistas, até mesmo porque na época em que a pesquisa foi realizada, estava-se em um período pós segunda guerra e as pessoas encontravam-se inibidas para se declarar abertamente fascistas, também compreende-se que os valores de um indivíduo 
expressam-se menos por palavras do que por atitudes e para conhecer opiniões sobre grupos minoritários ou mesmo opiniões políticas de uma pessoa, há que se levar em conta a situação em que ela se encontra para compreender o que pode ou não expressar de seu pensamento real. Ainda vale destacar que algumas opiniões e linhas de pensamento dependem do ambiente no qual a pessoa esta inserida e há algumas ideias que os indivíduos não são capazes de admitir nem mesmo para si próprios, quanto mais conseguir traduzi-los em palavras. Atualmente percebe-se um movimento similar ao verificar que poucas pessoas admitem-se ou podem admitir-se simpatizantes ao fascismo ou a movimentos declaradamente preconceituosos e segregacionistas de grupos minoritários, porém mesmo pessoas que não se declaram abertamente simpatizantes de tais ideais, acabam por demonstrar atitudes cotidianas que corroboram com o preconceito. Então faz-se importante investigar como o preconceito se reproduz não apenas de forma direta ou por aqueles que se declaram abertamente preconceituosos, mas sim também investigar as manifestações mais sutis do preconceito e também compreender o ambiente em que o indivíduo está inserido.

A pesquisa de Adorno, Brunswik, Levinson e Sanford (1965) utilizou como um dos métodos a elaboração de questionários que tiveram como objetivo investigar o preconceito de forma indireta e que estava expresso em vários âmbitos do cotidiano do indivíduo, compreendendo que o antissemitismo não é um fenômeno isolado na estrutura psicológica do indivíduo e que a suscetibilidade de um individuo a uma ideologia depende primordialmente de suas necessidades psicológicas. Para aprofundar tais investigações também foi utilizado um teste psicológico com vistas ao conhecimento de aspectos mais profundos da psique do indivíduo e entrevistas que investigaram o contexto ambiental e histórico familiar dos sujeitos que participaram da pesquisa. Ao investigar como as formas de preconceito podem começar a se manifestar em crianças de tenra idade, pode-se analogamente investigar como elas lidam com situações cotidianas de forma indireta e assim observar em suas atitudes qual a tendência que a criança apresenta para a reprodução de atitudes preconceituosas. Importante ressaltar que durante a investigação sobre o potencial de adesão à propaganda fascista, mesmo enfocando a estrutura psicológica do indivíduo como um importante fator que o torna suscetível a adesão a propaganda fascista, os autores Adorno, Brunswik, Levinson e Sanford (1965) não intencionaram reduzir a explicação sobre o preconceito e o fascismo a 
características psicológicas do indivíduo, compreendendo que tais características psicológicas só se manifestarão em determinadas situações e ambientes, ou seja, a personalidade do indivíduo seria mediadora entre a estrutura social e a ideologia.

Outro achado importante do estudo remete ao fato de que os indivíduos que mostram suscetibilidade à propaganda fascista têm muitas características de personalidade em comum, o que permite construir uma espécie de síndrome típica daqueles que tem potencial para adesão ao fascismo, ou um tipo de personalidade autoritária. Já os indivíduos que não apresentam propensão para adesão à propaganda fascista apresentam características de personalidade muito diversas. (Adorno, Brunswik, Levinson e Sanford , 1965). Para compreender esse padrão de personalidade com tendência à adesão a propaganda fascista fez-se importante investigar as ideologias ${ }^{2}$ individuais e as necessidades fundamentais dos indivíduos, compreendendo que as mesmas ideologias poderiam ter origens diferentes, assim como mesmas necessidades individuais poderiam se manifestar por ideologias também diferenciadas. Entende-se que as ideologias tem um funcionamento independente dos indivíduos e que resultam de processos históricos e de acontecimentos sociais do momento, exercem um certo grau de atração aos indivíduos que aderem às ideologias de acordo com que suas necessidades são satisfeitas ou frustradas, utilizando-as como forma de atingir ou justificar a frustração dessas necessidades. Levando em consideração essa relação entre as ideologias e os indivíduos, a pesquisa sobre a formação personalidade autoritária realizada por Adorno, Brunswik, Levinson e Sanford (1965) teve como principal objetivo investigar o individuo antissemita e tem como base a afirmação de que a formação do antissemitismo tem mais características relacionadas ao sujeito antissemita do que à população judia em si; e partindo desse principio levanta a hipótese de que o antissemitismo não é um fenômeno isolado no indivíduo de forma que o antissemita tende a manifestar outras atitudes preconceituosas e a hipótese de que a suscetibilidade à ideologia fascista no indivíduo depende também de suas características psicológicas. Tais afirmações se fazem importantes ao investigar o potencial de adesão ao preconceito em crianças pequenas pois apesar de suas atitudes ainda serem muito reproduções do que percebem dos adultos de seu

\footnotetext{
2 Segundo os autores, em suas próprias palavras, o termo ideologia é descrito como uma "organización de opinions, actitudes y valores: en suma, una manera de pensar sobre el hombre y la sociedad." (Adorno, Brunswik, Levinson e Sanford, 1965, p. 28).
} 
entorno, já pode-se começar a perceber quais discursos ideológicos elas se encontram mais propensas a reproduzir. Também se faz importante para justificar que pesquisas sobre o preconceito não precisam se ater apenas a um tema ou grupo sobre o qual o preconceito é direcionado, tendo em vista que as características preconceituosas podem ser generalizáveis para outros grupos e que um individuo que expressa atitudes preconceituosas direcionadas há um determinado grupo tenderá à expressá-las também para outros grupos.

Ainda vale destacar que, apesar de a investigação encabeçada por Adorno, Brunswik, Levinson e Sanford (1965) enfocar os aspectos psicológicos que fazem o indivíduo aderir à propaganda fascista e não a forma como ocorre a elaboração da propaganda fascista, não se limita a investigar a estrutura psicológica dos indivíduos, mas também o ambiente em que estão inseridos e as correlações entre as ideologias as quais um individuo adere e os fatores de sua vida pregressa ou atual que exercem influencia sobre a adesão do individuo à tal ideologia. Chegandose então ao conceito de personalidade que é entendido como um produto constituído pela história do indivíduo e portanto não pode ser compreendido apenas com suas formas de expressão no ambiente atual. Conceituando personalidade conforme as palavras dos autores:

El concepto de personalidad sirve para explicar la uniformidad relativa. Pero ha de recalcarse una vez más que la personalidad es principalmente una forma en potencia, una predisposición a determinado comportamiento más que el comportamiento mismo. Aunque consisten en disposiciones que inclinan a comportarse de cierta manera, la conducta que se concreta en la práctica dependerá siempre de la situación objetiva. (Adorno, Brunswik, Levinson e Sanford,1965, p. 32)

Compreende-se então que os autores não enxergam personalidade como um algo imutável do individuo, percebe-se, sim, que após desenvolvida as estruturas da personalidade encontra-se grande resistência para mudanças de comportamento mesmo ante a mudanças no meio social, o que explica a uniformidade relativa no comportamento de uma determinada pessoa, mas, há de se ressaltar que aspectos da personalidade necessitam de um ambiente favorável para se manifestar, exemplificado pelos padrões de normalidade e patologia que se alteram ao longo dos tempos e que permitem ou não a manifestação de aspectos individuais da personalidade dos indivíduos. Assim faz-se importante conhecer de forma igualmente aprofundada os aspectos mais flexíveis e os mais rígidos das estruturas 
de personalidade, pois apesar de admitirmos que certos tipos de personalidade tem maior adesão à propaganda fascista, vale investigar em quais condições e com qual intensidade tal propaganda se faz necessária para trazer à tona aspectos da personalidade que se encontravam latentes. Entende-se que a situação econômica e os grupos sociais em que o indivíduo está inserido também favorecem ou não a demonstração de alguns aspectos de sua personalidade, explicando inclusive porque alguns indivíduos tendem a agir de forma contraria a seus interesses, quando há para ele, importância na manutenção de seu papel em um determinado grupo social ou em uma determinada posição econômica. Se conhecer os aspectos que levaram à formação da personalidade de um indivíduo se faz importante para compreender suas relações com ambiente e sua potencial manifestação preconceituosa, por analogia reforça a importância de investigar a formação e o contexto em que se dá a formação da personalidade da criança, como forma de atuar na internalização de aspectos que se tornem contrários à adesão à propaganda fascista. Claro está que apenas uma intervenção precoce nos aspectos que delineiam a personalidade de um individuo não seriam suficientes e nem tampouco possível de ser realizado como forma de erradicação das atitudes preconceituosas, mas poderia ajudar na constituição de indivíduos que possuíssem mais elementos para resistir à propaganda fascista, ressaltando a importância da intervenção precoce quanto a aspectos da personalidade ligados a formação da personalidade autoritária.

Apesar de não estudar crianças na pesquisa sobre personalidade autoritária Adorno, Brunswik, Levinson e Sanford (1965) realizaram uma analise das entrevistas com enfoque nos aspectos aos quais os indivíduos contavam como foi sua infância e suas relações familiares desenvolvidas naquela época, análise realizada em capítulo escrito por Brunswik, o que nos dá um direcionamento para conhecer os efeitos que as relações na infância produzem sobre a formação da personalidade autoritária. O estudo parte do pressuposto que é no círculo familiar que as crianças aprendem a se relacionar com as demais pessoas com quem conviverão, e que os membros familiares ocupam posições distintas entre si e há grandes diferenças entre os valores que são importantes para as famílias, de forma que algumas possuem disciplinas mais rígidas e outras mais compreensivas. Observou-se como característica mais geral que as pessoas que obtiveram altas pontuações nas escalas, ou seja, pessoas que apresentaram um elevado potencial 
de adesão ao fascismo, remetiam imagem de sua família durante a infância como mais conservadora com pais vistos como idealizados, detentores de um poder reafirmado pelo autoritarismo e auto imposto, geralmente garantido pela dependência financeira dos filhos perante aos pais. Em sua avaliação já adulta sobre a família, os sujeitos que obtiveram altos escores tendiam a compreender-se como vitimas de uma educação rígida, injusta e por vezes violenta, porém depois de adultos reconheceram sentimentos de obrigação e gratidão para com a família. Também tenderam a identificar a família como um grupo superior aos demais, valorizando inclusive as questões de hereditariedade genética. Os pais destas famílias foram descritos como centralizadores, distantes, modelos de caráter e severos, já as mães eram tidas como submissas e bondosas.

As pessoas que obtiveram baixas pontuações nas escalas, ou seja, que apresentaram menor índice de adesão ao fascismo identificaram suas famílias durante a infância como mais compreensivas, apontando para mais momentos de conversas e regras fundamentadas em princípios, a percepção dos pais para estas pessoas se mostrou de forma mais objetiva, como reconhecimento de fraquezas e virtudes. Notou-se também a maior presença de afetividade nas relações e a percepção dos familiares como membros individualizados e não como um grupo fechado em potenciais dados pela hereditariedade genética. As recordações da figura paterna dada por esses indivíduos remetiam a pais presentes e afetuosos, sociáveis, interessados por atividades intelectuais e artísticas. As recordações atribuídas à figura materna também rememoraram afetuosidade, interesse por atividades intelectuais e artísticas, compreensão e sociabilidade. Vale destacar que as relações de poder entre pai e mãe foram mais identificadas como igualitárias entre as pessoas que obtiveram baixa pontuação nas escalas. Assim, pode-se concluir que as pessoas que apresentaram menor potencial de adesão ao fascismo identificaram em sua criação maior possibilidade de diálogo entre os pais com a compreensão de regras e não sua imposição. Já as pessoas que obtiveram maior potencial de adesão ao fascismo não identificaram em sua criação no seio familiar a possibilidade de discussão, o que pode auxiliar na reprodução do ideal autoritário e fascista nas relações sociais. Vale sempre lembrar que a pesquisa sobre o potencial de adesão ao fascismo se faz ampla para justamente não simplificar a questão, de forma que uma família mais conservadora ou uma família mais aberta ao diálogo não definem sozinhas o potencial de adesão ao fascismo ou a formação do 
preconceito. Mas os achados de características similares ao histórico de formação e educação familiar recebida por sujeitos que pontuaram mais altos índices para potencial adesão ao fascismo e características também similares na educação familiar recebida por aqueles que pontuaram baixos índices de potencial adesão ao fascismo permite estabelecer a correlação da importância de uma educação mais voltada para o afeto e para o diálogo como forma de auxiliar na formação de uma personalidade mais propensa a resistência a ideologia fascista. Importante destacar que no contexto atual de uma realidade brasileira se faz importante investigar para além da educação familiar que é passada para a criança, também a educação escolar tendo em vista que as crianças ingressam muito cedo na escola e sofrem forte influência desta. Por extrapolação, pode-se pensar também que uma educação escolar que favoreça o dialogo, o afeto e a busca por conhecimento em detrimento ao autoritarismo também podem auxiliar na formação de personalidades que apresentem maior resistência à ideologia fascista.

Outro fator importante para a compreensão da formação da personalidade autoritária segundo o estudo de Adorno, Brunswik, Levinson e Sanford (1965) foi o aprofundamento na análise realizada por Brunswik das características do psiquismo encontradas em pessoas com maior ou menor tendência a adesão à propaganda fascista tendo em vista que a maneira como um sujeito expressa suas atitudes preconceituosas revelam sua forma de lidar com seus mecanismos de estruturação psíquica, tal como descrita pela Psicanálise. Primeiramente foram avaliadas as características dos sujeitos de pesquisa de acordo com o pressuposto pela teoria do desenvolvimento psicossexual. A pesquisadora partiu da hipótese, avaliando características relacionadas à fase oral e à fase anal, de que os sujeitos que alcançassem pontuações mais altas tenderiam a rechaçar mais as características orais como o excesso de comida ou a verborragia, porém, nas pesquisas não encontraram diferenças significativas entre os indivíduos que obtiveram altas ou baixas pontuações no tocante a suas relações com as características orais. Já com relação as características da fase anal, os sujeitos que apresentaram altas pontuações nas escalas apresentam características morais rígidas que remetem a formações reativas anais, como por exemplo a importância exagerada ao dinheiro ou a ideologia de necessitar de um trabalho duro para conquistar os desejos. Já os sujeitos que apresentaram baixas pontuações nas escalas tendem a apresentar formações reativas anais mais funcionais como por exemplo a tendência a um 
pensamento organizado e estruturado. Pode-se então compreender que a primeira fase do desenvolvimento infantil denominada como fase oral e que é compreendida até aproximadamente dois anos de idade não mostrou diferenças significativas no desenvolvimento da personalidade no tocante ao potencial de adesão ao fascismo quando avaliadas em entrevistas com os sujeitos já adultos, dando indícios de que as crianças de tão pouca idade ainda não podem compreender as relações que constituem as bases para a formação do preconceito, ou mesmo pode-se pensar que crianças nessa faixa etária encontram-se mais protegidas e cercadas de afetuosidade, o que impede que formem estruturas psíquicas significativamente marcantes como características de potencial adesão ao preconceito. Já nas características avaliadas nas entrevistas com adultos que remetem à fase do desenvolvimento denominada fase anal do desenvolvimento psicossexual, que acontece a partir dos dois anos de idade, foram encontradas diferenças entre os indivíduos que apresentaram altos e baixos níveis de pontuação para o potencial de adesão ao fascismo, possibilitando a compreensão de que nessa fase a educação e as relações estabelecidas com as crianças já são importantes marcos para formação da personalidade e seu potencial de adesão ao fascismo.

Quanto à dependência e a agressividade como traços psicológicos presentes em diversas atitudes na vida dos indivíduos e mais ligados à fase do desenvolvimento psicossexual denominada como fase fálica e que se inicia por volta dos três ou quatro anos de idade, identifica-se a dependência dos indivíduos manifesta como a tendência a não assumir responsabilidades e a busca de apoio para justificar suas atitudes em sujeitos que apresentaram alta pontuação nas escalas. Ao avaliar as características da agressividade destaca a importância de se distinguir a agressividade que se constitui como uma raiva geral e difusa que tende a ser reprimida, mas pode surgir de modo incontrolável; da agressividade que se deve a uma situação em específico e vivida pelo sujeito e está mais bem integrada ao ego do sujeito. Ressalta-se o cuidado para que não haja confusão de uma agressividade integrada ao ego e direcionada a uma situação em específico a uma agressividade que é direcionada à um indivíduo ou a um grupo específico e que está apenas canalizando a agressividade expressa por uma raiva geral para um grupo como forma de manifestação do preconceito. Encontra-se nos sujeitos de pontuação alta mais exemplos do segundo tipo observado de agressividade e nos sujeitos de pontuação baixa o primeiro tipo descrito. Também diferem a agressividade que 
possui uma característica mais moral- autoritária, persecutória, que se encontra mais presente nos indivíduos de alta pontuação, da agressividade mais fundada em princípio, geralmente originada pelo impedimento de alcançar o objeto desejado; essa é mais identificada nos sujeitos de baixa pontuação. Por fim, ainda distingue a agressividade mais física e destrutiva, daquela que tende a se expressar de maneira mais regular e verbal; para essa categoria não se definiu uma diferença clara entre os dois grupos. A característica psicológica da ambivalência está ligada à agressividade, tendo em vista que se expressa frente à incapacidade de verbalizar agressividade ante figuras autoritárias; assim os sujeitos de pontuação alta tendem a negar a existência da ambivalência protegendo o endogrupo de qualquer ameaça mesmo que imaginária e responsabilizando o exogrupo. Já os sujeitos de pontuação baixa tendem a expressar a ambivalência, reconhecendo e avaliando as características dos indivíduos do endogrupo.

Outro ponto de especial importância na formação da personalidade é identificação com os progenitores, o que ocorre de acordo com a Psicanálise na elaboração do complexo de Édipo. Não foram encontradas diferenças relevantes entre os sujeitos de pontuação alta ou baixa nesse quesito. Porém esse processo de identificação com as figuras parentais dá origem a formação do superego, e aqui sim foi notado que os sujeitos que obtiveram altas pontuações nas escalas tem a tendência a externalizar o superego, ou seja, entendem a autoridade como algo externo a si, que é capaz de recompensar ou castigar. Já os sujeitos que obtiveram baixas pontuações conseguem internalizar o superego, orientando suas atitudes por valores propriamente seus, não dependente do julgamento de autoridades externas. Também os sujeitos de pontuação baixas nas escalas demonstram um ego mais integrado e fortalecido, capazes de sustentar esforços, postergar prazer e assumir responsabilidades, denotando maior maturidade emocional. Já as pessoas que apresentaram altas pontuações nas escalas tendem a mostrar maior debilidade do ego; porém também encontrou-se no resultado de algumas das pessoas de pontuação alta nas entrevistas exemplos de sujeitos que apontaram para o contrário e que mostraram-se dispostos à uma busca tenaz para o triunfo. Quanto à tendência a distorcer a realidade versus a capacidade de avaliar realisticamente as situações exteriores, percebeu-se uma maior tendência dos sujeitos que receberam altas pontuações à primeira situação e dos que receberam menor pontuação à segunda situação. 
Por fim, também como características psicológicas, avaliou-se nas entrevistas a organização cognitiva da personalidade sob os seguintes aspectos: intolerância versus tolerância, curiosidade científica versus superstição, capacidade de subjetivação versus necessidade de contato com a realidade e tendência a susgestionabilidade. Os sujeitos de pontuação alta mostraram personalidade com maior tendência à rigidez e à intolerância, necessidade de respostas mais dogmáticas o que os tornam mais supersticiosos, com maior dificuldade para pensamentos subjetivos e mais sugestionáveis, dependendo da opinião de uma autoridade para formar a sua. Já os sujeitos que obtiveram baixas pontuações nas escalas, mostraram-se com tendência a ser mais tolerantes, a buscar respostas mais científicas e menos dogmáticas, possuem boa capacidade de subjetivação e têm maior autonomia para criar suas próprias opiniões, tornando-se menos sugestionáveis.

Entende-se que os sujeitos de pesquisa que apresentaram maior potencial de adesão ao fascismo tendem a mostrar características do psiquismo com maior dependência da aprovação externa dada por um superego externalizado, mais intolerantes, supersticiosos, com tendência a formações reativas anais e com ego mais debilitado, distorcendo a realidade.

A avaliação das fixações na psiquismo do indivíduo relacionadas à fase fálica do desenvolvimento psicossexual auxilia na elaboração direta de uma correlação com o estudo proposto nesta pesquisa, tendo em vista que as crianças sujeitos da pesquisa encontram-se nesta fase do desenvolvimento infantil e a partir dos achados da pesquisa sobre a formação da personalidade autoritária pode-se depreender que a capacidade de uma auto analise e de se responsabilizar por suas atitudes, ou seja, a capacidade de internalizar as características do superego e de formar um ego fortalecido são importantes para a formação de uma personalidade com maior tendência a resistir a propaganda fascista e isso se faz especialmente importante ao relacionar o papel que a família e a escola tem na educação da criança nesta faixa etária.

Fazendo um recorte apenas para as avaliações das características do histórico familiar e de funcionamento psíquico expostas até aqui compreende-se que o foco de estudo sobre o antissemitismo foi se ampliando de forma que as conclusões do estudo poderiam ser generalizadas para o preconceito contra qualquer tipo de minoria. Observou-se que no sujeito preconceituoso a hostilidade 
oriunda das repressões e frustrações cotidianas da vida social necessitava ser deslocada por processos inconscientes para um objeto, com a finalidade de que esse sujeito conseguisse estabelecer relações menos conflituosas com a sua realidade. Esse objeto que se tornaria alvo do preconceituoso deveria possuir certas características como: estar próximo ao sujeito de forma que não seja tão próximo para que a realidade não seja vista e nem tão longe para que não configure importância, precisa ter uma raiz histórica e ter estereótipos rígidos e bem conhecidos e, por fim, precisa ter traços que harmonizem com as tendências destruidoras do sujeito preconceituoso. Assim, o preconceito termina por existir independente do alvo escolhido, pois poderia facilmente alterar seu grupo alvo com a finalidade de responder às necessidades inconscientes do preconceituoso. Dado que o estudo do preconceito pode ser, então, extrapolado para qualquer alvo, os autores se aprofundaram em descrever as características que permeiam o preconceito antissemita como forma de conhecer mais sobre o preconceituoso de maneira geral. Primeiramente discorrem sobre o caráter funcional do antissemitismo, enfatizando que o antissemitismo não depende tanto da natureza do objeto, quanto das próprias necessidades e desejos psicológicos do sujeito preconceituoso. Os sujeitos antissemitas canalizam sua agressividade para um alvo de preconceito e assim conseguem deixar de lado outros objetos que sentiriam como ameaçadores. Outra característica importante é que os alvos de preconceito se tornam o que os autores denominam de inimigos imaginários, pois percebe-se que os sujeitos preconceituosos tem pouca ou nenhuma relação específica com os sujeitos que compõe o grupo que é alvo de seu preconceito. A idealização sobre o alvo do preconceito também remete à ideia fantasiosa dos sujeitos preconceituosos de que o endogrupo tem todos os direitos e qualquer um que esteja fora deste grupo é visto como intruso. Assim, os autores questionaram a aproximação de grupos diferentes como forma de minimizar os preconceitos, pois entendem que embora valiosa em alguns casos, essa atitude funcionará até certa medida, tendo em vista que o preconceito se origina em raízes profundamente inconscientes, não há como corrigir a distorção perceptiva do preconceituoso apenas lhe mostrando fatos. E, dependo do contexto sócio-histórico no qual o sujeito está inserido, os grupos alvos de preconceito vão se modificando, de acordo com os modelos sociais.

Do ponto de vista psicanalítico pode-se questionar qual a função psíquica do preconceito, dado que ela ocupa um lugar na economia psíquica do sujeito e a 
resposta mais generalizada é a de que o preconceito tem na vida psíquica do indivíduo a função de satisfazer os desejos reprimidos e ao mesmo tempo atuar contra esses mesmos desejos. Entende-se então o antissemitismo, ou de maneira mais geral o preconceito, como um sintoma de caráter irracional que faz com que o individuo abandone o principio da realidade e desenvolva o ódio ante a determinado grupo. Quando o sujeito preconceituoso é convidado a pensar sobre sua atitude, inverte a relação entre experiência e estereótipo, personaliza sua atitude estereotipada como o resultado de uma experiência. No plano ideológico, é importante que os ideais preconceituosos são fornecidos e aprovados pela cultura e pelas normas democráticas predominantes, o que faz com que as atitudes do sujeito preconceituoso sejam racionalizadas moralmente pelo próprio sujeito. E assim, racionalizando, estereotipando e igualando as características dos indivíduos pertencentes aos grupos alvos do preconceito, no caso estudado os judeus, o preconceituoso chega ao seu ponto máximo que é o desejo de exterminar o grupo alvo de seu preconceito, justificando a periculosidade do grupo como algo natural ao grupo e que não será modificado.

Dadas a densidade e a importância teórica da obra "A personalidade autoritária houve uma grande produção de materiais que replicam e adaptam seus achados, e por outro lado teceu-se também inúmeras criticas à pesquisa e sob a forma como foi elaborada e que valem ser revistas junto com a análise da obra. Destacam-se aqui duas críticas que podem ser encontradas também nesta pesquisa: a acusação de que o estudo sobre a personalidade autoritária reduz o olhar sobre o preconceito a características psicológicas e a utilização da investigação social empírica como método da pesquisa. Crochik (2000) responde a ambas críticas, primeiramente lembrando que na conclusão da pesquisa os autores salientaram que um estudo sobre entendimento das características psicológicas que levam ao preconceito não significa a redução do preconceito a características psicológicas. Em suas palavras:

A ênfase que os autores dão nesse trabalho é à relação que existe entre as necessidades psicológicas e a adesão à ideologia, ou seja, o estudo de características psicológicas individuais é importante, não como elemento isolado para se entender uma questão que os autores insistem ser de gênese social, mas para evidenciar como a ideologia se reproduz a partir da incorporação individual, mediada por necessidades psíquicas. (Crochík, 2000,p. 74) 
Também sobre as características metodológicas desta pesquisa que envolve a criança como sujeito, não há intencionalidade de reduzir a formação do preconceito na criança a características psicológicas, mas sim, concorda com os autores referências para a pesquisa, compreendendo que o preconceito deve ser entendido em seu conceito amplo, no qual é importante entender as características individuais dentro da ampla perspectiva do social, não reduzindo o fenômeno apenas à psicologia ou à sociologia.

Quanto à segunda crítica que geralmente é direcionada para o estudo sobre a personalidade autoritária, aponta-se que a investigação social empírica pode levar a coisificação dos objetos; porém, não somente nessa obra, os autores da Teoria Crítica da Sociedade defendem a utilização da investigação social empírica como método nas pesquisas sobre o preconceito, apontando que os dados obtidos com esse tipo de método de pesquisa devem ser analisados levando em conta as condições sociais que os geraram, compreendendo que os dados obtidos não são frutos exclusivos dos indivíduos pesquisados, mas sim analisados criticamente como fruto da sociedade no qual o indivíduo está imerso. ( Crochík,2000)

Para finalizar esse capítulo sobre a obra 'A personalidade autoritária' ainda é necessário descrever brevemente o método de pesquisa utilizado. A pesquisa se deu pela aplicação de sucessivos questionários para a elaboração de escalas que intencionavam medir altos e baixos padrões de potencial à adesão da propaganda fascista. Aos sujeitos que pontuaram altos ou baixos escores nestes questionários foi aplicado um teste psicológico denominado teste de apercepção temática (TAT) e entrevistas possibilitando estabelecer a relação do psiquismo do individuo, seu histórico e suas tendências de adesão a expressões anti-democráticas. (Crochík, 1990).

Os questionários, como já mencionado, tiveram como propósito constituir escalas para detectar características da personalidade e posicionamentos sobre a posição política e econômica do sujeito. As questões foram dispostas de maneira intercalada para não permitir a percepção de um padrão de respostas e foram classificadas de acordo com o tipo Likert, de forma que a obtenção de um escore máximo nas respostas denotaria um elevado índice de antissemitismo, etnocentrismo ou fascismo. Constituíram-se quatro escalas: Escala de Antissemitismo (AS), Escala de Etnocentrismo (E), Escala de Fascismo (F) e Escala 
de Conservadorismo Político Econômico (CPE); devido à alta correlação obtida entre as três primeiras escalas, a escala $F$ substituiu as escalas AS e E. A escala $F$ teve sua forma final composta por 29 perguntas, as quais foram elaboradas com o intuito de avaliar indiretamente as atitudes potencialmente fascistas dos sujeitos de pesquisa.

A expectativa na construção da referida escala $F$ era a de que conseguisse captar o potencial antidemocrático, foi construída após as escalas AS, E e CPE, o que permitiu que a escolha das perguntas já direcionassem mais para a percepção do potencial de adesão ao fascismo. Sua primeira forma foi constituída por 38 itens e a forma final por 29 itens. A escala foi dividida em perguntas intercaladas que visaram identificar os índices de convencionalismo, submissão à autoridade, presença de agressividade autoritária para controlar outras pessoas, oposição a manifestação dos sentimentos e valores subjetivos, crença em poderes sobrenaturais, identificação com figuras que representam poder, hostilidade com a humanidade, crença de que o mundo pode submeter a castigos e preocupação exagerada com impulsos sexuais; utilizando perguntas que não deixavam explícito a intencionalidade do que se investigaria na pesquisa, pois como foi elaborada no pós segunda guerra mundial, todos os itens que remetessem a opiniões declaradamente fascistas seriam rechaçados pelos sujeitos de pesquisa. Esses itens foram posteriormente investigados também pelas entrevistas e pela aplicação do TAT e os resultados foram discutidos dando origem à obra "A personalidade autoritária. Para não tornar o texto redundante, deixar-se-á uma explicação mais detalhada sobre a construção da escala F para o capítulo em que está descrito o método empregado nesta pesquisa, tendo em vista que tal explicação é necessária para compreender como foi constituída a escala proposta na pesquisa. Após essa breve apresentação sobre alguns dos pontos principais da obra que deu origem à ideia dessa pesquisa, passa-se à apresentação e discussão teórica sobre o preconceito e a revisão de estudos relacionados à sua formação. 


\section{Preconceito}

\subsection{A criança e a formação do preconceito}

Crochík (2006) discute a complexidade de compreender como se dá a formação do preconceito, e ressalta que no individuo preconceituoso existe a presença de manifestações irracionais e inconscientes do próprio individuo, bem como efeitos do processo de socialização ao qual este é submetido; nas palavras do autor:

Para se falar em indivíduo, deve-se pressupor uma esfera de intimidade ou de interioridade, que se contraponha a uma esfera de exterior, mas é uma interioridade que surge a partir desse mesmo exterior, o que implica que o indivíduo é produto da cultura, mas dela se diferencia por sua singularidade. Quando o indivíduo não pode dela se diferenciar, por demasiada identificação, torna-se seu reprodutor, sem representar ou expressar críticas que permitiriam modifica-la, tornando-a mais justa; se o indivíduo somente se contrapõe a ela, não se reconhecendo nela, coloca a própria possibilidade de cultura em risco. (Crochík, 2006, p. 15)

O preconceito deve ser compreendido dentro de um contexto histórico, transmitido culturalmente por meio das gerações. O excerto aponta para a contradição de que, se por um lado, é na possibilidade de transmissão da cultura que surgem os elementos de resistência, pois com o processo de socialização os indivíduos podem repensar o que estão vivendo e assim auxiliar na transformação da cultura, por outro lado, a perpetuação do preconceito também reside nessa transmissão da cultura, que imputa ao individuo a impotência para realizar a transformação. Aqui vale lembrar que a noção de indivíduo é de constituição histórica conforme Galeão-Silva (2007), logo não há como formar indivíduos livres de preconceito em uma sociedade preconceituosa. Isso se faz especialmente importante quando estamos pensando na formação da criança, pois é nessa fase da vida que os elementos de socialização são apresentados ao indivíduo e é necessário cuidar para que sejam apresentados de forma a possibilitar a criança a identificação com a cultura para a formação de um sentimento de pertença, porém o desafio é conseguir despertar para a possibilidade de constituir critica a essa mesma cultura; entende-se que uma das maiores dificuldades está no fato de que as instituições socializadoras, como a escola e a família, por exemplo, também são constituídas na cultura o que gera a dificuldade em formar indivíduos capazes de se identificar e ao mesmo tempo de criticar a cultura. Horkheimer e Adorno (1973) 
apontavam que as condições proporcionadas pela sociedade eram melhores para aqueles que abdicavam de opiniões pessoais e da própria experiência, o que favorece a formação dos indivíduos preconceituosos tendo em vista que apenas reproduzem os conceitos que lhe são passados, sem a devida reflexão. Mas também apontam para a importância de conhecer as motivações ocultas do preconceito, como uma maneira de resistir a esse. Sendo assim, se por um lado a criança se forma na sociedade repleta de estigmas e preconceito, tornando se parte dela e por consequência também preconceituosa, por outro lado, é importante permitir que ela conheça os mecanismos que geram o preconceito como forma de pensar algumas possibilidades de transformação mesmo nesta sociedade.

Já Clark (1963) destacava que é possível encontrar em crianças menores de três anos de idade, padrões de comportamentos e atitudes que expressam o preconceito relacionado à raça ou à religião, tal qual o comportamento que se observa no adulto. Porém ele destaca que na criança esses comportamentos são mais facilmente modificáveis. Adorno (2006) também ressalta a importância da possibilidade de experiência para a criança de pouca idade para evitar os efeitos do preconceito, pois quanto mais possibilidades de viver experiências diversas é que poderá modificar os valores que lhes são transmitidos rumo à constituição de um meio social mais apto à diversidade e a expressão das diferenças, o que favorece a identificação entre os diferentes e inibe o desenvolvimento do preconceito. A possibilidade de contato com o diferente é exatamente um dos fortes argumentos apresentados pelos movimentos em defesa da educação inclusiva, alegando que quanto maior for o contato de todas as crianças com a diferença, maior será a possibilidade de que ela saiba lidar com situações diversas e crescer priorizando valores de respeito e aceitação das diferenças. Tal argumento tem sustentação nos estudos sobre preconceito da psicologia social nos escritos de Allport (1979) que propõe a hipótese do contato, enunciando que a melhor maneira de reduzir a tensão entre grupos diversos é possibilitar o contato entre eles. Porém é necessário fazer a ressalva de que o simples contato entre os grupos não é o suficiente para promover a constituição de uma relação de respeito mútuo entre grupos diversos e é ainda Allport (1979) quem descreve que há condições para que a hipótese do contato favoreça a diminuição do preconceito. Dentre elas descreve a necessidade de um apoio institucional que favoreça o contato amistoso entre os grupos, a necessidade de que as interações sociais tenham uma frequência que permita a constituição de 
relações significativas entre os membros dos grupos diversos e ainda aponta a necessidade de certa equidade entre as pessoas, envolvidas em uma atividade cooperativa. Sendo assim, entende-se que um primeiro movimento para a diminuição da constituição do preconceito entre crianças pode realmente ser a exposição da criança às diversas formas de expressão do ser humano, seja na questão racial, de presença ou ausência de deficiência, religiosa, sobre sexualidade ou quaisquer outra expressão humana que leve a constituição de grupos diferenciados socialmente. Investigando essa relação do contato entre grupos diferentes e a diminuição do preconceito, Ventura e Monteiro (1997) descrevem uma pesquisa que realizaram sobre a visão materna referente a escola de educação inclusiva e constataram, em revisão bibliográfica, que entre 18 investigações sobre o redução dos efeitos do preconceito nas situações de inclusão escolar ${ }^{3}$ na metade dos casos estudados o contato entre brancos e negros na inclusão escolar havia aumentado o preconceito e a esperada redução do preconceito ocorreu apenas em $13 \%$ dos casos. Mas fazem uma ressalva ao método utilizado nas pesquisas revisadas e continuam defendendo a educação mista apoiadas na necessidade de identificar que as experiências ocorridas na escola não representam o total de experiências ao qual a criança está submetida, de forma que é necessário investigar a variável do ambiente extra escolar no qual a criança está inserida como possível justificativa para a não diminuição do preconceito após o contato entre as crianças; os estudos verificaram as possibilidades de mudanças em um período de tempo relativamente curto e ainda a inclusão escolar, na maioria dos casos estudados, não é realizada da maneira a respeitar condições ideais. Destaca-se, portanto, que o contato da criança desde a mais tenra infância com grupos que são diferentes é importante para a constituição de uma formação com menor adesão ao preconceito, mas não se deve esquecer que é importante mediar o contato entre as crianças, o que denota a ambivalência pois por mais que se favoreça o contato entre as crianças, as mediações entre os diferentes grupos são realizadas por indivíduos adultos já imersos na cultura do preconceito, o que pode levar à uma mediação que favoreça a formação do preconceito.

\footnotetext{
3 Utiliza-se neste texto o termo inclusão escolar, diferentemente do termo integração escolar utilizado no texto original. A decisão pelo termo inclusão no corpo da pesquisa advém do texto original estar escrito em português de Portugal e, por esse motivo, o termo integração designado é o equivalente ao conceito de inclusão que utilizamos no Brasil.
} 
Pensando na mediação realizada frente ao contato entre grupos diferentes, é importante cuidar para que esta não apresente os grupos de maneira hierárquica, fazendo com que um grupo se sobreponha ao outro. Horkheimer e Adorno (1973) apontam que um dos truques da propaganda para adesão ao fascismo é justamente a divisão do mundo em dois polos, os bons e os maus, assim a identificação com quem é bom permite a descarga dos impulsos sádicos contra o grupo considerado mau e ainda reforça a condição de bondade, sem a necessidade de comprovação disto. Quando apresentadas desta forma as relações entre diferentes ainda busca a divisão entre aqueles que são bons e maus, a exemplo da inclusão da pessoa com deficiência na escola, na qual se vê a posição das crianças sem deficiência como uma negação de possibilidade de vir a ser a criança com deficiência (Cabral, 2011), colocando-se, na melhor das hipóteses, como cuidador e impedindo-se de enxergar ali outra criança com possibilidades diversas da sua.

Frente a essa possibilidade de contato com o diferente mediado pelos processos de socialização, alguns autores apontam que na sociedade atual já não é mais possível a possibilidade de experiência. Agambem (2012) relembra que Benjamim (1933) já havia discorrido sobre a impossibilidade de realização da experiência como um dos efeitos causados pelos horrores da guerra que geravam o inominável, mas Agambem (2012) acrescenta que não é preciso mais uma catástrofe para impedir a experiência: os fatos cotidianos já são capazes disso, e ressalta que apesar de imerso em várias atividades ao longo do dia, o indivíduo é incapaz de transformá-las em experiência: "O homem moderno volta para casa à noitinha extenuado por uma mixórdia de eventos...entretanto nenhum deles se tornou experiência." (Agambem, 2012, p.22) .Os indivíduos são levados a conhecer o mundo pelos olhos do outro ou pelo que a indústria cultural mostra; para ilustrar, pode-se pensar nas viagens que a criança, ou mesmo que o adulto realiza; antes mesmo de conhecer o lugar, já foi inundado por fotos, imagens e até mesmo guias de quais lugares visitar e o que sentir em cada lugar, por vezes mais importante que a viagem em si está a necessidade de relatar e registrar a viagem, adequando os sentimentos aos que já Ihe foram antes apresentados. Para Agambem (2012), a experiência fica vedada para a criança, mesmo quando ela pode conviver em situações nas quais existe a diversidade, pois o mundo e as sensações que deve apresentar ao conhecer já lhe foram dadas anteriormente. Isso se confirma com a observação de que qualquer questionamento da criança ante o novo ou diferente é tolhido em nome de 
explicações sobre as boas maneiras que, de forma implícita, reforçam uma condição de inferioridade do diferente que não deve ser exposta em perguntas ou palavras, mas mantida como um assunto que não pode ser abordado, dadas a dor que pode proporcionar ao individuo que compõe o grupo estigmatizado e à obediência as regras e costumes de polidez social, as quais regem que não se deve perguntar ou falar sobre assuntos que possam constranger o outro; nesse pressuposto já se aponta que a diferença é algo de ruim e constrangedor, sedimentando assim o preconceito. Os estudos de Batista e Monteiro (2004) reforçam essas afirmações e apontam que as crianças de pouca idade manifestam mais explicitamente 0 preconceito, pois ainda não conseguiram internalizar por completo as normas sociais, as crianças mais velhas declaram menos abertamente afirmações preconceituosas, mas o pensamento não deixa de existir, apenas é represado e exposto de forma socialmente mais aceita. Um exemplo de tema atual com campanhas de combate ao preconceito que não possibilita a experiência é a campanha sobre a diversidade sexual e a intencionalidade de ensinar nas escolas sobre as possibilidades de relações tanto homossexuais, quanto heterossexuais. Claro está a importância de ensinar para crianças a existência de todas as formas de realização da sexualidade como forma de minimizar o preconceito de identidade de gênero, porém a indústria cultural continua a produzir filmes e desenhos infantis que mostram apenas as relações heterossexuais, os pais e familiares direcionam o questionamento visto como inocente e jocoso sobre com quem a criança namora sempre para uma definição de resposta heterossexual, os brinquedos, as roupas e os móveis escolhidos para as crianças caracterizam a heterossexualidade, os textos selecionados em livros didáticos ou mesmo de literatura infantil também privilegiam as relações heterossexuais. Assim, apesar de se falar e ensinar para as crianças sobre as possibilidades de diferentes formas de relacionamentos afetivos, direcionase para o caminho da heterossexualidade, de forma que ao ter contato com o diferente, a criança já compreende como algo errado, o que dificulta sua possibilidade de constituição da crítica. As possibilidades da apresentação para as crianças de tais relações já são e devem ser consideradas um avanço no que tange á formação do preconceito, mas concordando com Agambem (2012) não se pode afirmar que essas crianças estejam vivendo a experiência transformadora nessas situações, porque por vezes o contato com o outro apenas modela o discurso e o 
comportamento do sujeito para o que é socialmente esperado denotando a constituição do preconceito sutil.

Compreendendo que o preconceito pode ser expresso de forma sutil ou flagrante, entende-se que no primeiro caso, o individuo preconceituoso neutraliza seus sentimentos ante ao grupo discriminado, mas não busca proximidade ou intercâmbio cultural com o grupo diferente. Já no preconceito flagrante, o individuo preconceituoso rejeita e ataca o grupo estigmatizado.(Galeão-Silva, 2007) Com a discussão sobre o preconceito recebendo foco nos grupos sociais, as manifestações públicas do preconceito vão sendo neutralizadas, mas isso não significa que deixem de existir, e a intolerância vai dando lugar a possibilidade de existência do grupo estigmatizado, desde que se mantenha afastado do grupo dominante. Novamente vale destacar a importância do processo de coibir manifestações agressivas, ou de preconceito flagrante, frente a grupos de pessoas potencialmente discriminados e percebe-se nas crianças que o contato com o diferente é mediado pelo adulto, senão de forma a criticar um conceito de desigualdade passado por gerações, pelo menos de forma a impedir manifestações de violência explícita ante aos grupos estigmatizados. Porém há de se notar que tal inibição de comportamento acaba por permitir a expressão do que denominamos como preconceito sutil, e embora a diferenciação dos grupos não seja expressada de forma violenta, continua mantendo um distanciamento e uma frieza na relação entre os diferentes.

Outro elemento de suma importância na formação da visão de mundo da criança é o brincar. Benjamim (1928) retoma a importância da criatividade como forma de constituir um pensamento crítico e transformador, e relembra que o brincar da criança representa essa oportunidade para compreender o mundo de forma crítica. Porém aponta que os brinquedos que reproduzem a realidade de forma fidedigna, impossibilitam a criatividade e produzem uma percepção de mundo mediada pelo capital. Avaliando os brinquedos produzidos para as crianças na atualidade, pode-se perceber o desenvolvimento de peças que simbolizam reprodução fidedigna da realidade, com a construção de estereótipos sociais que visam perpetuar a cultura. Importante destacar que embora o brinquedo tenda a reproduzir a realidade, o brincar é algo que transcende o próprio instrumento dado pelo brinquedo e a criança pode apresentar criatividade e potencial para a transformação na relação que constitui no momento do brincar, modificando a função do objeto que Ihe foi apresentado. Aqui entra a mediação do adulto nesse 
momento do brincar, que pode permitir a criatividade da criança ou tolher sua expressão. Hoje as famílias tendem a comprar brinquedos eletrônicos para seus filhos, o que não é um problema em si, tendo em vista que as crianças se interessam por esse tipo de produto e eles já estão incorporados ao seu convívio, o inconveniente reside no fato de que os brinquedos são comprados justamente para que a criança brinque sozinha, sem a necessidade da relação com outra criança ou com o adulto, reproduzindo os passos propostos pelo mesmo. Os brinquedos são muito criticados como responsáveis pela perpetuação dos estereótipos ou pela formação da violência nas crianças, porém é importante lembrar que para além do brinquedo está o ato de brincar e a mediação do adulto junto a criança nesse ato. Não se nega aqui a importância da produção, ou mesmo da retomada da produção de brinquedos artesanais, ou que priorizem a imaginação da criança, bem como de brinquedos que valorizem a diversidade em detrimento aos estereótipos, mas não se pode esquecer da importância de recuperar a relação entre crianças ou entre criança e adulto no momento do brincar.

A contradição presente na formação da criança contra o preconceito reside justamente no fato que apesar de ser na mais tenra infância que devemos atuar para combater o preconceito, são os adultos formados na sociedade do preconceito que irão mediar essa formação. Talvez seja justamente o reconhecimento da dificuldade, ou mesmo da impossibilidade, de uma formação com possibilidade de experiência e livre da transmissão de preconceitos que permita educar crianças para combater a barbárie. As esferas da escola e da família são hoje as maiores influências no processo de socialização das crianças.

Primeiramente direcionando o foco para o núcleo familiar no qual a criança está inserida e seu papel na formação do preconceito na criança, é necessário compreender como se forma a família a partir de sua contextualização histórica, que primeiro conforma-se em uma relação natural entre os indivíduos e que vai se diferenciando até chegar à constituição monogâmica atual, criando uma área distinta de relações privadas. (Horkheimer e Adorno, 1973A). Visto dessa forma a família é uma conformação social de pessoas que está inserida em um processo histórico, e como todo equipamento social tende a reproduzir e a responder aos movimentos inerentes da sociedade em que está imersa. Horkheimer (1936) argumenta que os grupos isolados, dentre os quais pode-se considerar a família, são momentos da construção da relação de transformação entre os homens e a natureza, ditados 
pelos interesses econômicos, e respondendo, portanto, a esses interesses. Concordando com o autor, Carvalho (1997) destaca que dentro de cada cultura que os pais pertencem eles encontram conjuntos de diferentes ideias, as quais aceitam algumas e rechaçam outras na transmissão de valores aos seus filhos, de forma que além da ação individual dos pais sobre as crianças, encontra-se a ação do contexto social em que vivem os pais.

Avaliando especificamente a sociedade brasileira quanto ao histórico sobre o preconceito racial, Galeão- Silva (2007) aponta sua constituição nesta sociedade de forma que os vínculos estabelecidos favorecem a submissão aos poderosos, especificamente o tipo ideal brasileiro dado pela miscigenação, não tende a inibir diferenças raciais, mas sim a submetê-las a uma escala de poder. Visto dessa forma, a constituição do preconceito contra raças e por extrapolação, a construção do preconceito contra as minorias não é ingenuamente reproduzida dos pais para os filhos, como um processo de herança moral natural e independente, mas sim são valores que correspondem aos interesses da cultura dominante. O racismo pode ser avaliado de forma a exemplificar tal transmissão de valores preconceituosos, pois hoje raramente se encontrará uma família branca, ou mesmo uma família composta por miscigenação ou por outras raças, que ensine literalmente aos filhos que as pessoas negras devem ser vistas como subservientes ou menos valorizadas, mas essa mesma família por muitas vezes não mantém em seu ciclo de amizades pessoas negras que tenham a mesma condição social, não frequentam lugares em que haja igualdade entre a frequência de pessoas brancas e negras, e acabam restringindo na maior parte das vezes, o contato entre pessoas brancas e negras apenas quando existe a condição de brancos como patrões e negros como trabalhadores culturalmente e financeiramente subalternos. Clark (1963) descreve seus estudos realizados em meados do século $X X$, nos quais observa que apesar de as famílias compostas por pessoas de cor branca não ensinarem seus filhos a manifestar palavras que desvalorizem a cor de pele das crianças negras, desde os primeiros níveis escolares as crianças vão se constituindo em grupos separados e desenvolvendo sentimentos negativos para os representantes de grupos com cor de pele ou raça diferentes dos seus, o que é tido como um movimento natural pelos pais, já que é uma reprodução do círculo social formado pelos próprios pais. Também aponta que as crianças negras tendem a se identificar mais com os sentimentos de desvalorização devido a cor da pele. Se por um lado não se pode 
culpar a essa família pela imagem de relação entre raças que está transmitindo à criança, pois ela apenas é reprodutora de um movimento social que é maior e mais forte do que a própria instituição familiar, por outro lado, percebe-se que é no microcosmo da família que há alguma possibilidade de questionar o valor que a criança recebe do meio social, logo a família seria responsável, dada sua constituição em poucas pessoas, por proporcionar a reflexão para seu filho em fase de educação e aquisição de valores. Mas o próprio Horkheimer (1936) aponta para a dificuldade em abolir e questionar valores culturais estabelecidos, pois para a diferenciação em castas ser abolida, a sociedade que a vive teria que abdicar de gozar dos benefícios adquiridos em anos de manutenção das diferentes classes sociais. A família então reproduz os valores sociais, inclusive os que levam ao preconceito, em parte porque está imersa na sociedade que prediz padrões comportamentais com $\mathrm{o}$ intuito de manter as relações entre dominantes $\mathrm{e}$ dominados, e também porque teme questionar esses valores e perder a posição alcançada.

Mas também há que se observar que a família ocupa um duplo papel na sociedade, se por um lado é responsável por manter a posição social vigente no microcosmo, por outro lado permite a proteção dos indivíduos ante as pressões do social. Horkheimer e Adorno (1973 A) apontam para a ambivalência a qual a família esta submetida, pois está cada vez mais exposta aos elementos da socialização necessitando negar sua característica individualizante, porém é justamente no seio familiar que os indivíduos vão buscar refúgio ante as forças totalitárias da sociedade. Sendo assim, a família acaba sendo vista como um elemento que contém potencialidades para a subversão da ordem vigente, e deve ser mantida subserviente aos valores da sociedade de forma bastante atenta. Tal manutenção da instituição familiar sob a égide do interesse social não ocorre de maneira forçosa ou autoritária, mas sim sob a utilização da razão e da percepção de que, como já apontou Horkheirmer "quem pretende chegar a algo, sim, em geral, quem não quiser soçobrar, deve aprender a ajustar-se aos outros" (1936, p.215), então a família percebe que precisa se esforçar para a adaptação para continuar sobrevivendo e oferecendo conforto aos seus descendentes. Como forma de não fugir dessa necessária adaptação, a família recebe e busca cada vez mais intervenção para que responda aos interesses do grupo social maior e é destituída de suas potencialidades na criação dos filhos, fazendo com que perca seu elemento autônomo. Hoje se assiste a uma crescente 
busca de auxilio profissional para a educação das crianças, que além de servir para reprodução do sistema social sem a possibilidade de crítica, reforça a frieza nas relações. Também nota-se a dificuldade em assumir uma postura parental ante os filhos, pois os pais distanciados dos filhos dado o tempo que necessitam ficar no trabalho ou mesmo o tempo expandido em que as crianças estão na escola, acabam por constituir uma relação sem intimidade e ambígua, mesclada por momentos de permissividade excessiva ou de autoritarismo sem justificativa, tendendo a compreensão de que o papel dos pais se limita a suprir as necessidades materiais impostas no sistema capitalista e aos profissionais, em especial a escola, o papel da educação moral.

A família cumpre cada vez menos a sua função de instituição de aprendizagem e educação. Na Alemanha, ouve-se dizer hoje, repetidamente, mesmo a respeito dos filhos de famílias de camadas superiores da sociedade, "nada trouxeram de casa"; e os professores universitários comprovam até que ponto é escassa a formação substancial, realmente experimentada pelos jovens, que possa ser considerada como pré-adquirida. Mas isso depende do fato de que a formação cultural perdeu a sua utilidade prática... Por parte dos filhos, a tendência atual consiste em furtarem-se a essa educação, que se apresenta como uma introversão patológica, e em orientarem-se, de preferencia, pelas exigências da chamada "vida real"- $\mathrm{e}$ isto muito antes de tais exigências se apresentarem , de algum modo, à criança. ( Horkheimer e Adorno, 1973 A, p. 143).

A citação acima se refere à crise na estrutura familiar alemã, que se generalizada para as demais localidades nos dias atuais corrobora o papel da família apresentado até então, no qual a educação cultural vira sinônimo de educação escolar e precisa se prestar a um propósito direcionado pelos interesses econômicos. A família tem o dever crescente de preparar a criança para seu futuro profissional, mesmo que ela não tenha idade ou maturidade ainda para lidar com as questões que a vida profissional irá lhe impingir. Esse tipo de educação se torna parcelar e o conhecimento integral dos processos históricos, manipulando as possibilidades de conhecimento que podem gerar algum tipo de mudança, o que acarreta problemas em dois âmbitos quando pensamos na formação do preconceito, pois se por um lado, como já citado acima, o distanciamento da família na educação dos filhos leva a perda da autonomia para valorização das pequenas mudanças e possibilidades de questionamento para o padrão social dominante; por outro lado, também gera crianças cada vez mais distanciadas dos pais e deste ponto de vista 
com maior potencial para frieza. Tendo em vista a preocupação parental com o futuro educacional e profissional dos filhos, as crianças estão cada vez mais imersas em educações para a competição, o que torna cada vez mais normal enfatizar a impotência do outro como forma de garantir suas qualidades, essas crianças percebem na dificuldade da outra uma oportunidade de conseguir melhores colocações, o que impede a transmissão de um valor importante, a empatia pela dor do outro ser humano.

Outro ponto de especial importância quando se remete ao papel da família na transmissão do preconceito para suas crianças é a relação entre pais e filhos com os sentimentos de agressividade e autoridade. Quanto à constituição familiar, Horkheimer (1936) destaca um costume familiar em que "o pai tem direito moral a submissão ao seu poder, não porque ele se mostre digno, mas ele se mostra digno porque é o mais forte”. (1936, p. 216). Entendendo que tal submissão autoritária já se constituía um problema quando inibe a possibilidade de diálogo e de identificação com a figura autoritária relegando à criança o papel de submissão, temos hoje uma estrutura de poder familiar no qual o autoritarismo pode ter sido substituído ou até mesmo expandido para outras figuras que alcançaram o posto de autoridade, sendo representada por vezes pela mãe, por outro familiar ou mesmo por pessoas ou 'coisas' externas à família, seja a escola ou elementos da tecnologia, o importante é que observamos na família a manutenção de uma relação de subserviência entre as crianças e um membro indicado como mais poderoso por obra de sua força e não de seu merecimento. Sobre essa relação de força, Horkheimer e Adorno (1973) relatam que as investigações psicológicas sobre os indivíduos que têm maior tendência a aderir ao preconceito apontam como uma das características dessas pessoas a existência de um passado traumático na infância, delineado pela criação dada com base em um pai excessivamente severo ou pela falta de afeto, o que corrobora com os achados na pesquisa sobre personalidade autoritária de Adorno, Brunswik, Levinson e Sanford (1965) já expostos no capítulo anterior. O processo para reversão desses aspectos, segundo Horkheimer e Adorno (1973) não passa apenas pelo esclarecimento formal das condições objetivas sobre o preconceito, mas sim é necessário fornecer a essas pessoas a capacidade para reelaborar e reestabelecer a capacidade de formar vínculos com pessoas e coisas. Ainda sobre as relações familiares, Adorno (2006) aponta que uma relação com a autoridade paterna violenta e repressiva na infância faz com que a criança tenha seu desenvolvimento impedido 
pela raiva reprimida contra a figura de autoridade, e por consequência só consiga se expressar a partir da identificação com essa própria autoridade repressora, imputando autoritarismo sobre os demais, geralmente sobre aqueles que identifica como mais frágeis. Ressalta também que as relações de frieza e distanciamento, que as crianças vivenciam no seio familiar, podem gerar algo similar ao que se chama de caráter manipulativo, caracterizado por pessoas frias e sem a capacidade de se relacionar. Com isso os autores não intencionam reduzir a explicação do preconceito a um trauma gerado no seio familiar pela falta de afeto ou pela autoridade excessiva na primeira infância, mas sim chamar atenção para a importância da família em proteger e amar as crianças como forma de fortalece-las para entrar em contato com o mundo, sempre lembrando que a formação e os valores familiares correspondem aos valores da sociedade em que estão imersos. As crianças estão cada vez mais cedo expostas às cobranças e expectativas sociais para o seu desenvolvimento como um modelo de adulto idealizado pela sociedade, sendo imputadas às figuras de autoridade e a relações autoritárias, com as quais são moldadas para obedecer. Horkheimer (1936) lembra que o que ocorre na família com a criança desde a sua mais tenra infância desempenha um papel fundamental para as decisões e valores no adulto que irá se tornar, e à família é dada a tarefa de educar pela autoridade:

Nesta situação familiar, que é decisiva para o desenvolvimento da criança, já é antecipada em ampla escala a estrutura de autoridade da realidade fora da família: as diferenças existentes nas condições de vida que o indivíduo encontra no mundo têm de ser simplesmente aceitas, ele deve fazer seu caminho sob essa hipótese e não mexer nisso. Conhecer fatos significa reconhece-los. (Horkheimer, 1936,p. 215)

Assim, compreende-se que a autoridade excessiva e arbitrariamente imposta na família prepara o individuo para aceitar a legitimidade dos processos de autoritarismo que acarretam o preconceito e também para a reprodução do status quo, de forma que o indivíduo criado sob essa perspectiva ao invés de questionar a autoridade arbitrária a qual é submetido, acaba reproduzindo o sistema e também imputando autoridade agressiva aos grupos a quem consegue submeter, impossibilitando a identificação entre os indivíduos e mantendo a necessidade da estratificação social. Vale destacar que ao questionar o papel da autoridade não se defende uma criação de crianças sem leis e sem regras, a autoridade é necessária para a criança compreender e conviver em ambientes sociais, o questionamento 
aqui se faz sobre a autoridade auto imposta e que gera conformismo e impossibilidade de reflexão crítica, levando a criança a naturalizar os processos sociais que lhes são apresentados, reproduzindo e internalizando o preconceito.

Convém agora discorrer sobre a outra base importante para a formação da criança e para a constituição da sua relação com o preconceito: a escola. Permitir que os indivíduos tenham educação escolar e o esclarecimento são obrigações da família e do Estado e contém em si uma oportunidade para lhe proporcionar experiências, evitando a formação do preconceito. No texto "O conceito do Esclarecimento", Horkheimer e Adorno (2006) já apontam para as contradições presentes no próprio esclarecimento que era possível na sociedade da época, indicando que esse era responsável por livrar os homens do domínio e do medo causado pela submissão ao mundo mítico; mas que o mesmo esclarecimento acabou por levar o homem à submissão à ideologia e à busca de um conhecimento cada vez mais preciso e que prescindia do conhecimento do homem em si, tornando-o coisificado.

Nos dias atuais, as crianças ingressam na escola com pouca idade, algumas com apenas alguns meses após o nascimento ou nos primeiros anos de vida. Devido à crescente procura pela educação escolar, a escola de educação infantil deixou de ter apenas o papel de cuidar da criança quando os pais necessitavam ir para o trabalho e passou a oferecer uma proposta de educação e de estimulação pedagógica planejada com o intuito de auxiliar no futuro desempenho educacional e profissional do adulto, vendendo hoje a ideologia da necessidade do ingresso na escola com pouca idade como uma forma de garantir um futuro educacional e profissional para a criança.

Adorno (2006) ressalta a importância de uma educação contra a barbárie ${ }^{4}$ na mais tenra infância para a eficácia no impedimento da formação de um caráter manipulador e que favoreça a adesão à ideologia fascista, para isso, aponta a necessidade da oferta de um modelo educacional que favoreça a experiência e a

\footnotetext{
${ }^{4}$ A definição de barbárie nas palavras de Adorno: "Entendo por barbárie algo muito simples, ou seja, que estando na civilização do mais alto desenvolvimento tecnológico, as pessoas se encontrem atrasadas de um modo peculiarmente disforme em relação a sua própria civilização - e não por não terem em sua arrasadora maioria experimentado a formação nos termos correspondentes ao conceito de civilização, mas também por se encontrarem tomadas por uma agressividade primitiva, um ódio primitivo, ou, na terminologia culta, um impulso de destruição, que contribui para aumentar ainda mais o perigo de que toda a civilização venha a explodir, alias uma tendência imanente que a caracteriza."(Adorno, 2006B,p. 155)
} 
possibilidade de que as crianças possam se identificar com os outros, evitando a constituição da frieza nas relações e da consciência coisificada. Daí a importância de que a criança tenha na educação a possibilidade de brincar com outra criança e perceber os limites de respeito e desejo imposto nessa relação de troca, perceber na relação com o adulto os comportamentos que precisa adquirir e mesmo imitar para se manter no grupo social e iniciar a possibilidade de crítica aos comportamentos que não deseja reproduzir. Não cabe aqui a ideia romântica de retrocesso a uma sociedade sem o recurso da tecnologia, mas sim a apresentação dos recursos tecnológicos para a criança a partir da mediação do ser humano. É importante ressaltar esse tipo de educação não remete somente à educação escolar, mas sim à educação vista de forma integral, incluindo os valores familiares e sociais que são passados para as crianças desde pequenas. Na sociedade de hoje a escola assume um duplo papel: o da educação formal e o de transmitir valores morais e éticos para as crianças, outro motivo que leva à procura dos modelos educacionais que estimulam a busca por escolas de educação infantil que promovam conteúdos culturais, cursos extracurriculares, acesso à tecnologia; sempre na ânsia da escola que mais ofereça cultura e tecnologia para o pequeno estudante, geralmente movidos pelo medo de deixar de oferecer a melhor educação para o filho e assim condená-lo à exclusão da sociedade no futuro, mesmo que para isso já estejam preparando as crianças para a frieza nas relações típicas do caráter manipulador descrito por Adorno "No começo as pessoas desse tipo se tornam por assim dizer iguais a coisas. Em seguida, na medida em que conseguem, tornam os outros iguais a coisas".(Adorno, 2006, p.130). Aqui, então, já se pode perceber uma clara contradição da busca pelo esclarecimento, pois, se por um lado, as crianças têm cada vez mais cedo o acesso à educação formal, por outro, esse acesso vem geralmente mediado pela ideologia da racionalidade tecnológica, impedindo a experiência e transformando as crianças em depositários de informações acumuladas como forma de maior bagagem para competir na sociedade quando se tornarem adultos e para continuar a reproduzir o modelo vigente.

Se a educação escolar, inclusive na modalidade do ensino infantil, é vista como norteada pela ideologia da racionalidade tecnológica, faz-se então necessário primeiramente compreender as origens e como a ideologia da racionalidade tecnológica afeta as relações educacionais ocorridas na escola. Conforme Crochík (2003) essa ideologia vem permeando as relações entre os homens desde o 
desencantamento do mundo produzido pelo esclarecimento, o que provoca no homem a constante necessidade da dominação. O progresso que deveria libertar os homens da necessidade do trabalho, proporcionando para ele uma condição verdadeiramente humana, acabou por aprisioná-lo a uma necessidade de dominação contínua, encantando um mundo desencantado e fazendo com que os homens sempre busquem dominar o que já não há mais para ser dominado e sempre mantenham a necessidade de trabalhar em um mundo que não necessita mais do trabalho, ou pelo menos do trabalho que aprisiona o humano e que já poderia ser realizado pela máquina. Com isso a qualificação exigida para os empregos torna-se maior e com mais níveis de escolarização, mas as atividades exigidas no trabalho não são mais complexas e nem os salários mais igualitários e permitindo condições de igualdade econômica, logo a educação escolar gira em torno de si mesma produzindo mais necessidade de escolarização sem a proposição de maiores ensinamentos ou de maiores reflexões. A tecnologia produzida propaga, novamente, a libertação do homem da escravidão do trabalho; possui uma fachada de neutralidade e contém em si a ideologia de proporcionar a igualdade entre os homens, deixando aparentemente igual o que é desigual. Mas a ideologia apenas aprisiona ainda mais esse homem, que busca uma liberdade que já poderia ter sido conquistada e se coisifica se submetendo à máquina. Nas palavras do próprio autor:

O mundo gira em falso. O trabalho do qual já se poderia prescindir, torna-se imprescindível; a tecnologia que deveria libertar, aprisiona, e como a contradição é cada vez mais visível, a descrença é inevitável; contudo quanto menos há fé, mais ela se torna necessária e o indivíduo subjuga-se ao que é contrário aos seus interesses mais racionais. (Crochík, 2003, p. 34)

A tecnologia traz em si elementos que permitem o avanço, mas a ideologia da racionalidade tecnológica é fonte de sofrimento e angústia para os homens. Hoje essa ideologia vem sendo imputada às crianças desde o inicio da sua vida, propagada pela educação escolar que é programada para atender às necessidades do trabalho, mesmo que não seja diretamente voltada para ele. Pode-se esperar, então, que as crianças submetidas a esse tipo de formação tornem-se adultos cada vez mais propensos a comportamentos preconceituosos, definidos pelo caráter manipulador e pela coisificação dos indivíduos. Já nas escolas infantis assume-se o modelo de educação voltado para o trabalho e para a ideologia da racionalidade 
tecnológica quando substituem o trabalho e a possibilidade da relação livre entre professor e aluno por programas de educação pré concebidos para atender a sistemas de ensino, ou mesmo por livros didáticos ou materiais programados de forma massificada, como se não houvesse diferenciação entre as formas de aprendizagem ou as experiências de vida dos jovens aprendizes, igualando-os da forma como postulado pelo pensamento tecnológico. As diferenças não são valorizadas, possibilitando realizar o humano, mas sim disfarçadas ou negadas, igualando o homem a coisas que podem ser compreendidas de antemão. As relações entre as crianças são enfraquecidas em modelos que tendem a separar e diminuir as trocas entre os grupos de pares, sob o pretexto de que as crianças devem circular por vários grupos de alunos como forma de conhecer e amar a todos. Já escreveu Freud (1930) que amar a todos é amar ninguém, mudar constantemente as crianças de grupos na sala de aula, exemplo de comportamento frequente nas escolas atualmente, faz com que elas enfraqueçam suas possibilidades de relação entre si e enxerguem o outro ser humano como uma peça, facilmente substituível quando não está mais disponível em sua rede de contatos. Ofertar cada vez mais conteúdos desde muito cedo proporciona informação à criança e não a possibilidade de construção do conhecimento a partir da experiência. Ainda ao pensar o papel da educação escolar na formação da criança, deve-se lembrar que Adorno (2006) afirma que as crianças precisam ser protegidas da exposição à frieza e à barbárie, como forma de se prevenir a reincidência do horror ocorrido em Auschwitz. Importante ressaltar que quando se remete à necessidade de proteger a criança da frieza nas relações na educação escolar, não se está abrindo mão da necessidade de que haja uma diferenciação nas relações entre professor e aluno mediadas pela autoridade. Segundo Adorno (1972) a autoridade cumpre o seu papel de que um indivíduo com mais conhecimento sobre determinado assunto possa transmiti-lo ao aprendiz, que deve absorver esse conhecimento, pois somente a partir deste ponto consegue começar a constituir suas próprias experiências. A tentativa de igualar aprendizes e mestres a partir da ideologia da racionalidade tecnológica, como quando por exemplo, se prescinde da mediação do ensinamento do professor para realizar diretamente a pesquisa de conteúdos desconhecidos, reforça a pseudoformação, pois além de não proporcionar experiência ao aprendiz, ainda possibilita a falsa ilusão de que o indivíduo prescinde de outro humano e da experiência real para se formar. Se 
Horkheirmer e Adorno (1973) mostram que a falta de afeto durante a infância é comum naqueles que apresentam características mais totalitárias e que a modificação dessas características depende da reelaboração na capacidade de estabelecer relações espontâneas, o modelo de educação infantil que impede o contato com a criança já na tenra infância, pode ser visto como um elemento facilitador para a perpetuação do preconceito.

A educação escolar e o ingresso com pouca idade na escola não contêm somente elementos regressivos, mas também elementos de progresso. Não se pode negar a possibilidade de esclarecimento para o indivíduo e nem tampouco observar que o olhar para a criança, seus direitos e suas necessidades são mais discutidos e mais elucidados atualmente, muito disso se deve à contribuição da escola e das possibilidades de expressão que ela permite à criança pequena, ampliando seu círculo de contatos para além da família. Adorno (1972) reconhece que o modelo educacional da burguesia deve ser superado, mas que também foi a partir deste modelo que os burgueses conseguiram avantajar-se ante os camponeses constituindo riquezas, logo esse modelo, enquanto não superado, deveria ser possível a todos os indivíduos. Ampliar o acesso e o tempo de escolarização para a criança é uma forma de ofertar o modelo educacional vigente para todos. Também não se trata aqui de negar os progressos e benesses conquistados com a utilização da tecnologia, o mundo atual é impensável sem seus recursos e a formação das crianças também já utiliza a tecnologia como recurso para facilitar e ampliar as possibilidades cognitivas e motoras destes jovens aprendizes. Se a criança de tempos anteriores precisava sentar-se e atentar para o quadro verde riscado pelo giz branco, a criança de hoje espera, além desse recurso, poder assistir a vídeos, jogar no computador e até tocar na lousa eletrônica para assim acessar recursos oferecidos por essa, o que inclusive pode facilitar o acesso de todas as pessoas, incluindo aquelas que possuem algum tipo de deficiência sensorial, motora ou intelectual, à educação.

Para além da função socializadora, a escola tem como principal função a educação formal. Adorno (1972) estabelece a formação como a apropriação subjetiva da cultura, lembrando que a cultura ao mesmo tempo que remete à sociedade, também faz a mediação entre esta e a formação. Na sociedade atual o que é possível de ser ofertado aos educandos é a pseudoformação, mediada pela cultura que está sob a dominação, o que imputa à formação uma reprodução de 
elementos que servem para a adaptação e para a submissão. Sendo assim, nesta sociedade apenas temos a oferta da pseudoformação, tendo em vista que a formação precisa de autonomia e liberdade para acontecer. Sobre os riscos da pseudoformação:

A não cultura, como mera ingenuidade e simples ignorância, permitia uma relação imediata com os objetos e, em virtude do potencial de ceticismo, engenho e ironia qualidades que se desenvolvem naqueles não domesticados - podia elevá-los à consciência crítica. Eis algo fora do alcance da semiformação ${ }^{5}$ cultural. (Adorno, 1996, p. 397)

Entende-se que a pseudoformação leva o indivíduo à ilusão do conhecimento e à busca incessante por mais informações, impedindo o contato do aprendiz com o conteúdo de sua formação para que, possa apreendê-lo e consiga transformar a si próprio e a realidade que se encontra ao seu entorno, ter acesso ao indivíduo antes de seu ingresso inicial na educação escolar formal e ter a possibilidade de planejar uma educação menos parcelar e com acesso a obras completas não impediria a pseudoformação, mas favoreceria a expansão da possibilidade de consciência crítica. Assim a criança pequena pode ser um bom exemplo daquele que está exposto à não cultura, pois ainda encontra-se em seu contato inicial com os valores da família e da sociedade representada pela indústria cultural. Responder aos questionamentos da criança e oferecer a ela possibilidades de experiência são formas de possibilitar uma formação mais ampla. Partindo dessa premissa, então, o ingresso da criança pequena na educação infantil mediada pela ideologia da racionalidade tecnológica acaba fornecendo, desde muito cedo, a pseudoformação, o que já possibilita na criança adaptação ao modelo social e impede a constituição da crítica, um dos elementos que torna o indivíduo propício para a propagação do preconceito.

Benjamim (1933/1996) aponta que estamos cada vez mais expostos a possibilidades de aprendizagem e da informação, porém, também cada vez mais longe de um verdadeiro contato com essas e, por consequência, mais impossibilitados de utilizar o esclarecimento como uma forma de combater a barbárie. Sobre a relação entre a experiência e a barbárie o autor escreve:

\footnotetext{
${ }^{5}$ Apesar da citação literal da tradução para o português utilizar o termo semiformação, neste texto há preferência pelo termo pseudoformação, entendendo-se que a expressão não refere uma formação pela metade, mas sim uma formação incompleta e com fins para a adaptação.
} 
Pois qual o valor de todo o nosso patrimônio cultural, se a experiência não mais se vincula a nós? A horrível mixórdia de estilos e concepções do mundo do século passado mostrou-nos com tanta clareza aonde esses valores culturais podem nos conduzir, quando a experiência nos é subtraída, hipócrita ou sorrateiramente, que é hoje em dia uma prova de honradez confessar a nossa pobreza. Sim, é preferivel confessar que essa pobreza de experiência não é mais privada, mas de toda a humanidade, Surge assim uma nova barbárie. (Benjamin, 1933/1996, p. 115)

No excerto acima fica evidente a critica de Benjamin ao acúmulo de informações, que dão ao indivíduo a impressão de possuir o saber, quando, na verdade, ele não consegue se apropriar deste conhecimento para sua própria individuação. O que corrobora a crítica que Adorno (1972) tece à pseudoformação, ou seja, oferta de informação e instrumentalização para lidar com a cultura, mas sem a possibilidade de internalizá-la. Sobre a importância do papel da mediação para a aprendizagem realizada pelo professor, podemos traçar um paralelo com Benjamin (1936/1996) que faz a distinção entre a informação e a narrativa, explicando que a informação só tem valor no momento em que é passada, ou seja, é um instrumento que não poderá ser incorporado ao individuo. A narrativa ${ }^{6}$, em contrapartida, permanece junto ao indivíduo permitindo que elabore e internalize o conteúdo narrado. Na pseudoformação, a informação se sobrepõe à narrativa, o papel do professor que transmite conteúdos e faz a mediação entre o aprendiz e o conteúdo a ser aprendido vai sendo cada vez mais superado e invadido pela racionalidade tecnológica, seja a partir do livro didático que rege quais caminhos o professor deve seguir, seja pela utilização de programas de computador ou mesmo de equipamentos de tecnologia que interagem diretamente com o aluno, passando informações a serem aprendidas de maneira imediata. Por vezes, a própria possibilidade de narrativa do professor se encontra suprimida na relação com o aluno, sendo que o professor necessita transmitir conteúdos previamente estabelecidos e ditados como se estivesse para além de sua capacidade de conhecer, o professor é cada vez mais desvalorizado ante os recursos da indústria

\footnotetext{
6Em seu texto "O narrador" Benjamin (1936/1996) destaca o papel do narrador como aquele que se apropria dos fatos a partir da experiência, tomando certa distância do conteúdo a ser narrado e ao mesmo tempo aproximando esse conteúdo de suas experiências de vida. Assim o narrador é capaz de comunicar experiências e, por isso, permitir que as aprendizagens do ouvinte também se transformem em experiências.
} 
tecnológica, sendo transformado também ele num recurso para a aprendizagem e privado de sua possibilidade de interação imediata com o aluno. Além da superficialidade na formação acadêmica do indivíduo, esse modelo reforça a frieza nas relações e o ideal de que o contato com a tecnologia substitui o contato com o humano e pode superá-lo. Bem como fornece a ilusão de que os educandos são detentores de todo o saber e de que tudo que há para ser conhecido já foi estudado e explicado, impedindo a possibilidade de transformação. O texto Literário "O conto da ilha desconhecida”, escrito por José Saramago, em 1998, satiriza essa ilusão do conhecimento que impede a constituição do novo saber causada pela pseudoformação: na história, quando o personagem principal do livro solicita um barco ao rei para procurar por ilhas desconhecidas e seu pedido é negado sob a afirmação de que todas as ilhas já são conhecidas. O interessante no texto, avaliando-o sob o referencial da crítica a pseudoformação, é perceber que o mesmo elemento que paralisa também provoca inquietude, pois quando a certeza da ciência é questionada, por exemplo no trecho: “ Quem foi que te disse rei, que já não há ilhas desconhecidas, Estão todas nos mapas, Nos mapas só estão as ilhas conhecidas, E que ilha desconhecida é essa de que queres ir à procura, Se eu to pudesse dizer, então não seria desconhecida "(Saramago, 2010,p.17), o qual ilustra que é justamente no questionamento à pseudoformação que reside a possibilidade de transformação. Ou seja, se a pseudoformação dá a ilusão de que não há mais nada a ser conhecido, também faz com que o estudante apenas assimile e reproduza o discurso do preconceito assim como ele está, normalizando as atitudes preconceituosas.

Portanto é necessário reconhecer os limites na educação escolar, especialmente nesse caso na educação escolar infantil, para que haja superação. Segundo Crochík (2006), o preconceito não é inato e nele estão presentes os processos de socialização do indivíduo e o esforço que ele faz para se adaptar, daí depreende-se a importância do papel da escolarização infantil e a oferta de diversos tipos de experiência nessa etapa da vida. Retomando Adorno (2006), é especialmente nessa época da vida que se deve proteger a criança contra a dureza e a barbárie da vida, daí a importância de lhe oferecer relações de aprendizagem mediadas pelo professor, reforçando a importância do contato especificamente humano em detrimento da presença da tecnologia. Adorno (2006) reforça ainda a importância do amor para a criança nesta fase da vida como forma de prevenção à barbárie, mas alerta que esse amor não pode ser mediado por relações estritamente 
profissionais e nem ser fornecido pelo adulto que não o obteve anteriormente e não tem contato com o amor, pois isso geraria mais frieza. Daí a importância, novamente, do contato entre a criança e os profissionais de educação e também entre as crianças e o grupo de pares, pois é a partir desse contato que existe a possibilidade da experiência nas relações e o surgimento de um amor genuíno entre os indivíduos, o que justifica um contato ampliado entre os humanos e não diminuído ou mediado pela tecnologia.

Adorno (2006A), em um debate com Becker, remete à importância que a adaptação tem na educação, como forma de possibilitar a vida em sociedade, mas remete aos riscos para o indivíduo; pois é necessário que a criança possa reconhecer as regras e consiga se subordinar a estas para que exista a mínima possibilidade de convívio junto ao grupo, porém a adaptação total do indivíduo sem a possibilidade de questionamento também leva à adesão ao totalitarismo. Há também a necessidade de ofertar, já na educação infantil, o contato com as obras originais, e não apenas com releituras simplificadas, para permitir que a criança possa instalar a verdadeira experiência com o conhecimento e não se contentar com conhecimentos parcelares, tomados como verdade e possibilidade única. É importante permitir a conscientização sobre as diferenças e não somente reforçar as igualdades, para que as crianças possam estar livres dos mecanismos de defesa constituídos pela formação reativa e pela repressão, não se sentindo intimidadas quando convidadas a conhecer o novo, ao contato intimo com o desconhecido que permite a modificação do si mesmo. Adorno (1972) aponta que o pseudoculto encontra valor em sua formação pelo ideal de ter possuído alguma vivência e não pela experiência dessa em si, como afirma: 'basta a frequência a um certo colégio' e não o que se aprendeu nesse colégio, e isso leva à necessidade de uma série de afazeres e de informações para manter a aparência de bem informado. A apresentação de conteúdos sem mediações e sem possibilidades de alteração da realidade levam à fetichização e a subjetivação da impotência no aprendiz, que não quer modificar e sim apenas adaptar; a oferta de aprendizagens e saberes socialmente construídos permite a criança fazer parte do saber, compreender seu processo de formação e lançar hipóteses sobre este, quebrando a perpetuação dos preconceitos que são passados de geração em geração.

O problema que leva à perpetuação do preconceito não está no ingresso da criança na educação infantil com pouca idade ou no seu contato mediado pela 
tecnologia, mas sim se deve atentar para que a educação infantil não seja mera extensão da educação escolar e já inicie oferecendo à criança, desde cedo, a adaptação para a pseudoformação. Se, como já visto, vale destacar a importância de se educar contra a barbárie desde a mais tenra infância, justifica-se fortalecer a necessidade do ingresso da criança na educação infantil, porém tomando a devida precaução para que esse início do processo de escolarização possa ser oferecido a criança a possibilidade de constituir resistência à ideologia da racionalidade tecnológica, fortalecendo a formação do espírito crítico e dando a possibilidade da criança buscar em seu futuro acadêmico a minimização dos efeitos da pseudoformação, mesmo que para isso tenha que reconhecer os limites de sua formação dentro da sociedade atual.

Até este ponto tentou-se estabelecer conceitos para delimitar o que entendese nesta pesquisa por preconceito e as formas com que a criança toma contato com as atitudes preconceituosas. Segue abaixo um levantamento bibliográfico destacando pesquisas clássicas e pesquisas atuais que investigam o preconceito.

\section{2 - Revisão bibliográfica sobre preconceito}

Foi realizado um levantamento bibliográfico com o elemento definidor preconceito, o que trouxe como resposta produções que se encontraram divididas, em sua maioria, pelo estudo dos diferentes alvos de preconceito: etnia, religião, sexualidade e deficiência. O maior número das pesquisas também está relacionado ao adulto e suas reações ante o preconceito. Na tentativa de limitar o número de pesquisas a partir da proximidade com o objeto de estudo, foram selecionados os materiais que relacionaram preconceito e infância. Importante destacar que foi entendido como estudo sobre o preconceito também as pesquisas que relataram sobre bullying, pois como muitas utilizaram o universo escolar como campo da pesquisa, o referido termo é utilizado como forma de estudar expressões do preconceito entre crianças. Foram encontradas apenas poucas pesquisas que utilizaram como sujeitos crianças com idade similar aos desta pesquisa, ou seja, entre três e quatro anos; as demais tendem a iniciar os estudos com crianças a partir dos seis anos de idade. Ao investigar o público dessa faixa etária a maioria das pesquisas estuda o meio em que a criança se encontra inserida. Segue então um breve relato dos resultados encontrados que, de alguma forma, encontram-se relacionadas ao objetivo desta pesquisa. 
Para iniciar a revisão utilizar-se-á as pesquisas que abrangem os meios de comunicação que apresentam as diferenças para as crianças, em sua maioria as histórias infantis. Retoma-se primeiramente a tese de referência na área elaborada por Amaral (1992) que realizou um estudo sobre a representação da diferença corporal utilizando a análise do conteúdo expresso nas obras da literatura infanto juvenil. Na pesquisa, Amaral (1992) selecionou os textos que possuíam personagens com representações de alterações físicas, sejam estes personagens humanos, animais ou objetos. A tese apresenta extensos achados e discussões sobre a representação que a literatura faz da pessoa com deficiência física, destacando a divisão que a autora estabeleceu entre as histórias altamente preconceituosas - nas quais a deficiência é tida como punição por alguma característica condenável do personagem - as histórias denunciadoras de preconceitos -nas quais a autora classifica as histórias sem a intenção de disseminar o preconceito, mas que reforçam a visão da diferença como algo a ser super compensado - e por fim, as histórias livres de preconceito - que identifica por histórias que descrevem as situações de deficiência física porém sem julgamento de valores ou emoções, sem tentativas de cura ou de compensação. Outro ponto da tese que vale ser destacado por sua consonância com os objetivos desta pesquisa é a sugestão que a autora deu à guisa da conclusão, para que se realizassem pesquisas relacionando as histórias que retratam a deficiência e a experiência de vida de seus autores, o que pode ser entendido como valorização do papel que a experiência tem na aquisição e na transmissão do preconceito. $E$ também o dado encontrado por Amaral que mais se aproxima com a intenção desta pesquisa é o relato e a avaliação que a autora faz de uma obra infanto juvenil escrita por uma criança de oito anos de idade ${ }^{7}$. O livro narra a descoberta de um cachorro advindo de outro planeta que é levado a fazer uma cirurgia para se adequar aos padrões físicos do nosso planeta e, posteriormente, o veterinário que fez a cirurgia é levado a conhecer o planeta do cachorro e tem que fazer uma cirurgia para se adequar aos padrões daquele planeta. Amaral (1992) não incluiu essa história em seu material de pesquisa por ter tomado conhecimento dele após o término da sua análise dos dados, mas destacou a perspicácia do autor, ainda criança, em perceber os

\footnotetext{
${ }^{7}$ ALBUQUERQUE, Diego. Branquinho, o dognauta. Rio de Janeiro, Codecri, 1982.
} 
processos de homogeneização presentes na sociedade. Vale destacar um trecho do livro que enuncia a visão crítica sobre a diferença apresentada pela criança:

No dia seguinte levei o Branquinho para dar um passeio. Logo que nós chegamos na rua foi a maior confusão: juntou um monte de gente curiosa, querendo saber porque ele era tão diferente. Resolvi levar o branquinho no veterinário, para consertar a cara dele. Afinal, para poder viver em paz aqui na terra, Branquinho tinha que ter cara de um cachorro da terra, senão, ninguém ia dar sossego a ele. (Albuquerque, citado por Amaral, 1992, p. 378)

No excerto acima nota-se a percepção da criança autora do livro sobre a necessidade de se adequar estereótipos sociais para ser aceito. Retomando que o autor da história tinha, na época em que escreveu, oito anos de idade, pode-se depreender que já existe a percepção da necessidade de se adequar a um padrão de aparência física predominante como forma de evitar o preconceito e também a crítica a isso. Apesar de se enquadrar em apenas um caso e de não possuir o contexto em que a criança estava inserida para realizar uma avaliação crítica do material, concordo com Amaral (1992) quando destaca a importância singular da visão apresentada pela criança na obra e sua história repleta de significações ante o estigma e o preconceito.

Outros pesquisadores também realizaram estudos com o intuito de verificar como a literatura transmite a diversidade para as crianças, destacados aqui a pesquisa de Doria (2008) que analisa como os livros e histórias infantis retratam o preconceito e mostra a expressão desses nas histórias contadas para as crianças. Já Barreiros e Vieira (2011), estudaram uma obra da literatura em específico 'As tranças de Bitou', escrita por Sylviane Diouf, e ressaltaram a importância de personagens principais representantes das minorias étnicas em obras de literatura infanto-juvenil, como forma de proporcionar elementos de identificação para as crianças. As produções científicas que avaliam obras literárias, materiais didáticos e produções para a indústria fonográfica, televisiva e cinematográfica são de grande importância para compreender como os conceitos de imagem social que são transmitidos para a criança, sempre lembrando que todo o material produzido para a criança é feito nesta e para esta sociedade, o que faz com que tenda a ser um conteúdo que espelha os padrões e costumes dos indivíduos que fazem parte da sociedade, de forma que todo o conservadorismo ou toda a proposta de avanço e de retrocesso presentes, tendem a ser retratados nesse tipo de material. Relacionar 
aqui todo o material de avaliação científica sobre o conteúdo produzido pela imprensa, televisão, rádio ou cinema para o público infantil tornaria essa revisão muito extensa, por isso o cerceamento em pesquisas que relatam explicitamente a relação entre essas produções e a formação do preconceito, mas vale a indicação sobre a importância de um maior aprofundamento nesse tipo de pesquisa.

Para além da indústria cultural que permeia o mundo do imaginário infantil, as pesquisas sobre preconceito na infância também delineiam seus estudos com base na relação estabelecida entre as crianças e os adultos que são responsáveis por sua formação, sejam profissionais da educação ou seus familiares, e como esses adultos lidam com possibilidade de contato com o diferente. Peters (1985) propôs uma pesquisa longitudinal com pais negros de crianças negras, com o intuito de investigar como eles preparavam seus filhos para lidar com o preconceito e a discriminação. A cidade em que a pesquisa foi realizada não está especificada no artigo, sabe-se que o país foi os Estados Unidos da América. Como sujeitos de pesquisa foram selecionados pais de crianças com idades entre dois anos e meio e dez anos, e eles foram observados por um período de dois anos em suas intervenções com seus filhos quando eles eram expostos a algum tipo de situação discriminatória, seja imputada a própria criança ou vivenciada pelos pais. A pesquisa apontou que a maior parte das famílias não entende como é possível preparar a criança para conviver com a discriminação, porém entende que ela sofrerá preconceito ao longo de sua vida e irá desenvolvendo capacidades para lidar com as situações. Os pais também entendem que a melhor forma de auxiliar seus filhos ante o preconceito é educá-los com amor.

No ambiente escolar temos diversas pesquisas que estudam a relação entre as crianças e o preconceito, dentre elas Sekkel, Zanelatto e Brandão (2009) investigaram como os funcionários de uma escola de educação infantil reagem à educação inclusiva e como favorecem o clima propício à constituição da experiência entre as crianças, utilizando para tanto observação nas relações estabelecidas entre as crianças e mediadas pelo adulto, entrevista com os funcionários e professores da escola e levantamento de documentação dos alunos tidos como em situação de inclusão. O estudo concluiu que a escola reproduz as contradições do ambiente social na qual está imersa, submetendo as crianças à escassez do compartilhamento de experiências que também é vivenciado pelo adulto na constituição de relação com o diferente. 
As pesquisas de Peters (1985) e de Sekkel, Zanelatto e Brandão (2009) apontam a relação e a forma como adultos responsáveis pela educação da criança lidam com questões relacionadas ao preconceito, e pode-se observar que em ambas ocorre resignação e tendência à reprodução do modelo atual de preconceito, educando-se as crianças para saber lidar com as situações quando se sentirem vítimas do preconceito e não estimulando a possibilidade de alteração das condições objetivas que levam ao preconceito. Claro está a importância de crianças advindas de grupos potencialmente vítimas do preconceito fortalecerem sua capacidade de lidar com situações agressivas como forma de evitar o histórico de sofrimento vivenciado por outras pessoas que apresentam condições semelhantes. Porém também é importante possibilitar à criança, pertencente ou não a grupos potencialmente vítimas do preconceito, sentimento de indignação ante as condições objetivas que levam ao preconceito.

Uma das referências em relação a pesquisas sobre o preconceito é Frances Aboud. Coordenada por essa pesquisadora foi realizada uma revisão bibliográfica com os artigos publicados entre 1980 e 2010 que versaram sobre como o contato entre crianças de maiorias e minorias étnicas influenciavam na redução do preconceito, o que foi publicado por Aboud et all (2012). A revisão incluiu apenas pesquisas realizadas com crianças de idade igual ou inferior a oito anos, valorizando a proposição de que o contato com a diversidade deve ocorrer em tenra idade para auxiliar na minimização do preconceito. Os resultados encontrados na revisão apontam que $40 \%$ das pesquisas mostraram resultados positivos para redução do preconceito racial em crianças que mantiveram relações interpessoais com diferentes grupos étnicos. Em $50 \%$ das pesquisas não foram encontradas diferenças significativas com relação à manifestação do preconceito e $10 \%$ das pesquisas apontou para um resultado negativo quanto à manifestação do preconceito. Os resultados encontrados por Aboud et all (2012) ainda destacaram que as pesquisas estudadas apontaram melhores resultados para relações estabelecidas em condições de igualdade entre as crianças com diferenças étnicas e também para relações estabelecidas no contato pessoal entre as crianças, ressaltando a importância da imagem transmitida pela mídia na impossibilidade do contato físico entre as crianças.

Também vale destacar dentre as pesquisas recentes na área o estudo de Cruz (2014) realizado entre os anos de 2001 e 2004, na cidade de São Paulo, 
diretamente com estudantes do quinto ano do ensino fundamental. O objetivo do estudo foi averiguar como eram constituídas as relações entre as crianças no cotidiano escolar, especialmente no tocante ao desenvolvimento de estratégias de sobrevivência ante a desigualdade social. Foi realizado um estudo etnográfico no qual os pesquisadores dividiram com as crianças os espaços de sala de aula e recreio para realizar entrevistas questionando situações de racismo e sexismo entre os alunos, bem como aplicaram escalas de auto percepção quanto à identidade de raça. Como conclusão a pesquisa aponta para o sofrimento presente nas crianças quando vítimas de ofensas verbais baseadas no contexto cultural que privilegia as ofensas ligadas ao gênero e à raça. Também nesse estudo verifica-se a tendência de manutenção das condições que permitem a expressão preconceituosa, e as crianças utilizam como estratégia para se defender da agressão sofrida agredir também ao outro ou buscar se adequar aos padrões sociais pré-determinados. Notase que a pesquisa aponta as questões de raça ou gênero não sendo compreendidas pelas crianças em seu caráter histórico e social, de forma que, por exemplo, as crianças compreendem que agredir a criança negra com insultos como 'beiçudo' tem a mesma conotação racista que a expressão 'leite moça' para a criança branca. Também percebe-se a atitude de branqueamento quando nos formulários de autodeclaração de raça a maioria negra se declara como morena ou 'café com leite'. Daqui novamente pode-se discutir a necessidade de possibilitar às crianças a compreensão das condições históricas que levam ao preconceito, pois apesar de ser realizada uma importante repressão dos insultos por parte dos adultos, a criança não consegue compreender a dimensão histórica e social de violência e preconceito que alcança a sua brincadeira, perpetuando as condições vividas atualmente.

Relacionando os achados encontrados por Cruz (2014) e pela revisão realizada por Aboud (2012), pode-se notar a importância do contato social pautado na diversidade, porém sem que o contexto seja discutido e mediado com o objetivo de diminuir as manifestações preconceituosas não haverá alteração das condições objetivas que levam ao preconceito. Sim, o contato com a diversidade tem grande importância, inclusive no tocante ao direito de expressão e de participação social para os grupos historicamente discriminados, porém somente a exposição a diversidade leva ao risco de manter a estratificação social entre os grupos dominantes e marginalizados como propõe Martins (1997), e ainda possibilita o agravante de manipular informações insinuando que a possibilidade de acesso aos 
equipamentos sociais como escolas por exemplo, já garante em si a igualdade de condições e anulação de um processo histórico de discriminação, de maneira que se pode imputar a culpa pelas expressões de preconceito à sua própria vítima. Não basta possibilitar o contato entre os diferentes, mas é necessário alterar a forma como as relações estão estabelecidas entre os grupos, concordando com os estudos sobre a hipótese do contato realizados por Allport (1979).

Retomando que esta investigação entende que a intervenção com vistas a minimizar os efeitos do preconceito deve ser realizada de maneira precoce na criança, direcionou-se o levantamento bibliográfico para pesquisas com crianças de pouca idade, porém encontra-se que a maior parte dos sujeitos de pesquisa tem idade equivalente ao esperado para o ensino fundamental, ou mesmo são adolescentes. As três pesquisas encontradas com crianças de menor idade foram as Cruz (2015), de Kawashima (2007) e a de Porter (1973). A pesquisa de Cruz (2015) faz um estudo com crianças de três anos de idade, alunos de uma creche da rede pública de uma grande cidade brasileira, a pesquisa utiliza a observação das crianças no momento escolar e dois principais instrumentos, sendo a exposição de fotos de crianças brancas e negras buscando que as crianças sujeitos de pesquisa comentassem livremente sobre as fotografias e como outro instrumento a utilização de duas histórias que expressavam potencial situação de preconceito e as crianças deveriam continuar a história, em ambos os instrumentos, caso a criança não fizesse menção à diferença de cor, os pesquisadores iriam investigar melhor possibilitando a expressão da diferença. Vale destacar no método desta pesquisa a importância dada para a linguagem e a forma de expressão própria da infância, com a opção da pesquisadora por oferecer materiais ilustrados e que atraíssem atenção da criança pequena. O referencial teórico utilizado na pesquisa é a obra de Henri Wallon e a discussão dos dados empíricos coletados remete à conclusão de que as crianças pesquisadas na referida faixa etária ainda não foram impregnadas por um colorido afetivo, seja ele positivo ou negativo, no tocante à cor de pele, pois não expressaram percepção ou mesmo falas em que se encontrassem traços de preconceito com relação a cor. Vale destacar nas palavras da própria autora à guisa da conclusão de seu artigo: 
As condições sociais têm um peso bastante relevante, mas as experiências vividas concretamente pelas crianças dão um sentido peculiar ao que elas se apropriam, aos sentidos que atribuem às coisas; e esse sentido tem forte relação com a forma própria com a qual elas lidam com o mundo objetivo, que não é inferior, mas é diferente da que predomina entre os adultos. ( Cruz, 2015, p. 12)

Esta primeira pesquisa citada é a que encontra maior consonância com os objetivos a que se propõe este trabalho, apesar de possuir referencias teóricos distintos, ambas apontam para a importância do contato entre as crianças com características diferentes e para a mediação que favoreça uma experiência positiva nestas relações, no caso da pesquisa de Cruz (2015) com o intuito de favorecer a formação de um afeto positivo e no caso desta pesquisa com o intuito de promover a identificação entre os diferentes, de forma que a criança enxergue no outro diferente uma possibilidade de vir a ser.

Como já citado, outra pesquisa com crianças de pouca idade é a de Kawashima (2007) que estudou a partir da observação e da entrevista com professores o comportamento conflituoso de crianças entre quatro e seis anos no tocante ao desenvolvimento moral segundo a teoria piagetiana e sua relação com a discriminação e violência na escola de educação infantil. A pesquisa, realizada na cidade de São José do Rio Preto, em São Paulo, identificou que as crianças avaliadas perpetuam as condutas discriminatórias aprendidas com os adultos, mas a maioria considera errado o conflito compreendendo a norma de obediência à autoridade. Esses achados podem indicar que apesar de reproduzir conteúdos preconceituosos, a criança ainda não possui clareza de suas atitudes e repete o comportamento que depreende das relações entre adultos. Já o estudo realizado por Porter (1973) se propôs a conhecer a gênese do preconceito e seus efeitos em crianças americanas com idades entre três e cinco anos. Para tanto a autora utilizou o brincar como técnica, solicitando que as crianças utilizassem bonecos para criar estórias infantis para televisão, dessa forma fornecia bonecos brancos e bonecos negros. As crianças deveriam criar estórias primeiramente sobre uma situação escolar e depois sobre uma situação social representada por uma festa de aniversário; quando iniciada a brincadeira, a entrevistadora passava a perguntar sobre qualidades dos personagens brancos e negros, como qual o mais agradável ou o mais preguiçoso. Por fim a pesquisadora solicitava que a criança agrupasse as 
duas bonecas que achava mais parecidas, de forma que esse agrupamento poderia se dar por identificação da cor da pele da boneca, da cor do vestido da boneca ou por gênero. Para Porter (1973), as crianças entre três e cinco anos ainda não estão conscientes do significado de raça enquanto categoria social, mas atribuíam um significado com grande carga afetiva quando percebiam que as diferenças de cor possuíam significado social. Os dados pesquisados por Porter, sobretudo no tocante a idade dos sujeitos de pesquisa e ao método utilizado são consonantes com a proposta desta pesquisa. Vale destacar que os estudos de Porter não utilizaram a teoria crítica como referencial teórico e limitaram-se à importância da constituição do preconceito dado o conceito de raça, mostrando indícios de que mesmo antes de compreender ou de atribuir o significado as diferenças de categorias sociais, a criança já atribui valor afetivo à cor da pele, identificando com mais adjetivos ruins a cor negra e com mais adjetivos bons a cor branca, o que contrapõe-se aos achados de Cruz (2015). Nesta pesquisa intenciona-se continuar as investigações realizadas por Porter, Kawashima e Cruz à luz da compreensão do preconceito dada pela teoria crítica da sociedade, bem como pesquisar a visão da criança de forma mais genérica sobre o preconceito, investigando as categorias raciais, de gênero e presença ou ausência de deficiência.

Outras importantes pesquisas sobre a manifestação do preconceito em crianças também foram encontradas como a de França e Monteiro (2004) em que se propuseram a investigar o racismo em crianças e a testar a hipótese de que crianças menores apresentam características de racismo que tendem a declinar com o aumento da idade e com a aquisição da cultura. Para tanto realizaram a pesquisa com crianças entre cinco e sete anos, e com crianças entre oito e dez anos, em escolas do estado de Maceió. Foram aplicadas três situações de testagens nas crianças, sendo que a primeira visou identificar a percepção das crianças sobre a possibilidade de igualdade, a segunda sobre a percepção do racismo e a terceira sobre a percepção da norma antirracismo. A conclusão obtida pela pesquisa é que as crianças mais novas tendem a expressar mais diretamente o racismo, porém não se pode afirmar que as crianças mais velhas não apresentem o racismo, mas sim que internalizaram a norma antirracismo e a apresentam em forma de preconceito sutil. 
Fernandes, Almeida e Nascimento (2008) investigaram a expressão do preconceito racial em crianças brancas com idade entre cinco e oito anos, residentes no interior do estado de Sergipe. Para tanto solicitou-se que as crianças desenhassem separadamente uma criança branca e uma criança negra, que atribuíssem categorias sociais de riqueza, beleza, contato e proximidade aos personagens desenhados e, finalmente, que atribuíssem um desenho de casa e família aos personagens. Como resultados observou-se que os desenhos representando crianças brancas foram considerados como personagens mais bonitos, mais inteligentes e com mais atributos socialmente reconhecíveis do que os desenhos representando crianças negras. Os desenhos representando famílias não diferenciaram os personagens brancos ou negros. Os autores concordam com os resultados obtidos na pesquisa realizada por França e Monteiro (2004), indicando que já é possível observar preconceito em crianças de pouca idade, e que as crianças mais velhas tendem a internalizar mais as regras sociais, exprimindo o preconceito de forma sutil em detrimento do preconceito de forma flagrante.

Já Oliveira (2007) investigou a presença de atitudes preconceituosas partindo de estudantes brancos em direção a negros. Para tanto, aplicou um questionário em adolescentes com idades entre doze e dezoito anos, residentes na cidade do Porto, com objetivo de avaliar semanticamente os atributos fornecidos aos alunos brancos e negros no que concerne à simpatia, beleza, inteligência, entre outros conceitos socialmente reconhecidos. Como resultados percebeu-se que os alunos brancos não demonstram atitudes negativas em relação aos alunos negros, porém avaliam o endogrupo ao qual pertencem - brancos- mais positivamente que o exogrupo dos negros. Concordando com as duas pesquisas supra citadas, a autora também ressalta a internalização das normas sociais, as quais ela atribui à campanha anti racismo na Europa, impulsionada desde 1997, que substitui as formas de expressão do preconceito racial por expressões mais sutis.

Rodrigues, Monteiro e Rutland (2010) avaliaram as percepções antirracistas e o favoritismo endogrupal em crianças portuguesas com idade entre seis e onze anos. Como instrumento foi pedido para que as crianças expressassem como um grupo de adultos brancos, representados por uma fotografia, valoraria o seguinte grupo de afirmações se fossem ditas pelas crianças: "Brinco muito com os meninos negros", "Os meninos negros me fazem feliz", "Não brinco com os meninos negros", "Os meninos negros me deixam zangado", "Gosto mais dos meninos brancos porque 
sou branco como eles", "Brinco mais com os meninos brancos porque sou branco como eles". Como resultado, observaram que aos seis anos existe um favorecimento da questão do endogrupo e que as crianças possuem dificuldade em regular seu comportamento seguindo as normas antirracistas. A partir dos sete anos e de forma crescente conforme a idade, a internalização das normas antirracistas são atribuídas ao endogrupo e orientam as respostas das crianças. A pesquisa aponta para a importância do modelo social como forma de regular as manifestações de preconceito racial nas crianças.

Com o objetivo de identificar os efeitos do preconceito sutil na formação de identidade na criança, Almeida (2012) aplicou um questionário solicitando que as crianças identificassem em brancos e negros as categorias de beleza, riqueza, inteligência, escolhas para o brincar e para adotar um irmão. Também foram aplicadas escalas para medir o autoconceito e o autocontrole em crianças negras com idades entre 11 e 12 anos, estudantes de escolas públicas de uma cidade do interior do estado de Sergipe. Como resultados observa-se que a maioria das crianças se autodeclara como branca ou morena, apesar de esta percepção não ser a mesma que a de juízes que atribuíram uma cor de pele para essas crianças; esse dado leva à proposição da presença de um autoconceito de branqueamento entre as crianças. Com relação à atribuição dos estereótipos, observa-se que as crianças brancas recebem classificações mais positivas do que as crianças negras em categorias como beleza, inteligência e riqueza. A escala de autocontrole determina que a maioria das crianças possui nível baixo de autocontrole, e a escala de autoconceito também aponta que a maioria possui um nível baixo de autoconceito. Os resultados obtidos nessas duas escalas podem explicar, segundo o autor, a tendência ao branqueamento apresentada pelas crianças, como tentativa de evitar o conflito determinado pelo preconceito.

Costello e Hodson (2012) estudaram a relação entre o preconceito racial direcionado a crianças negras e a tendência à desumanização, utilizando para tanto a hipótese de que a marginalização de seres humanos reside na atribuição de características não humanas aos exogrupos e isso se justifica pela crença de que os homens são superiores aos animais. A pesquisa foi realizada com crianças canadenses brancas de ambos os sexos com idade entre seis e dez anos e também com seus responsáveis. Constatou-se que as crianças brancas tendem a atribuir menos características exclusivamente humanas para as crianças negras do que 
para outras crianças brancas. A pesquisa também evidenciou que esse comportamento das crianças segue o modelo do comportamento apresentado por seus pais. Como conclusão, os autores sugerem a necessidade da aproximação e do respeito nas relações interespécies como forma de diminuir o preconceito.

Rutland, Killen e Abrams (2010) revisaram a teoria da cognição social para investigar a formação do preconceito em crianças pequenas, estabelecendo a contraposição entre a identidade de grupo e o desenvolvimento moral de equidade e justiça. Comparam as respostas entre crianças de seis, nove e treze anos, quanto à percepção do exogrupo ante à necessidade de se inserir em um grupo social. Concluem que as normas sociais para fazer parte de um grupo ameaçam o desenvolvimento moral, e consequentemente a formação do preconceito, desde muito cedo na criança. Complementando esses dados, vale retomar a pesquisa de Gómez e Huici (2008) em que apontaram a melhora da imagem do exogrupo para crianças de um determinado grupo quando sofriam a intermediação de uma figura de autoridade, reduzindo o preconceito intergrupos, modificando os estereótipos e diminuindo a discriminação. Porém se faz importante destacar que os sujeitos das duas pesquisas diferem em idade e em local, sendo que a pesquisa de Gómez e Huici (2008) foi realizada na cidade de Madri com adolescentes entre 15 e 18 anos.

O artigo produzido por Piccolo (2011), como síntese de sua dissertação, traz os resultados da observação do brincar de crianças entre cinco e seis anos sem a mediação de adultos com o objetivo de investigar a manifestação de preconceitos nesses momentos e utilizou a análise de excertos ocorridos durante a observação. Mostra como resultado a reprodução do discurso preconceituoso nessas crianças, como forma de manter a posição social dentro do grupo. Antunes (2008) se propôs a pensar como a introdução do conceito de bullying teve a função de mascarar os problemas sociais, dentre eles o preconceito, que levam à violência escolar, explicando a violência como uma questão individual e não social. Em sua pesquisa realizou grupos de discussão com seis adolescentes estudantes do oitavo ano de uma escola municipal com o objetivo de avaliar as posturas perante frases que justificavam cenas de violência escolar em trechos de filmes que foram apresentados aos adolescentes. Como resultado apontou que o denominado bullying nas escolas brasileiras tem a função de atribuir ao indivíduo a culpa pela violência, mas que na verdade é um comportamento produzido pela reprodução do preconceito e da rigidez social ante o diferente. 
Avalia-se que as pesquisas realizadas com crianças apresentam resultados semelhantes indicando que as crianças tendem a se relacionar com o preconceito de modo mais sútil com o avançar da idade, tendo em vista que internalizam as proibições sobre a forma de expressar opiniões e pré-julgamentos, mas isso não indica que deixam de diferenciar e de discriminar os grupos que são socialmente diferentes, valorizando o endogrupo que se encontra em posição socialmente dominante.

Uma crítica às pesquisas encontradas é que apesar de se direcionar ao público infantil, poucas envolvem o brincar como instrumento de pesquisa, sendo que essa é a forma mais natural para a criança expressar suas formas de ver o mundo que a cerca. A maioria das pesquisas pede que a criança emita valores ou adjetivos para situações ou imagens, observa-se que os valores emitidos pelas crianças tendem a reproduzir o que aprendem ou interpretam do contato com os adultos, porém como a expressão desses valores se dá a partir da linguagem verbal, também tendem a reproduzir a forma como é transmitida pelo adulto. Utilizar o brincar como instrumento de pesquisa pode favorecer a expressão da criança, talvez mostrando alguma diferenciação da forma como o adulto vê as situações de preconceito, ou mesmo indicando como as representações preconceituosas vão sendo formadas para a criança. Fazzi (2009) traz em seu artigo a preocupação central de que a pesquisa com crianças deve ser interpretada a partir da lógica do pensamento infantil e não do pensamento adulto, pressupondo que a realidade e o raciocínio da criança seja diferente do adulto. Para tanto ela cita como fonte de exemplo metodológico sua pesquisa na qual investigou como a criança aciona e experimenta as noções raciais na relação com outras crianças e como a criança aprende o significado de ser de uma categoria racial ou de outra. Uma das principais preocupações metodológicas apresentadas por Fazzi (2009) foi a de que o pesquisador não interferisse na observação das crianças, para tanto ela optou por se integrar com os sujeitos de pesquisa, crianças de 6 a 14 anos estudantes de duas escolas situadas em bairros com classes sociais diferentes na cidade de Belo Horizonte, para tanto participava das aulas e momentos de recreação, não atuando como educadora ou impondo regras para as crianças. Iniciou a pesquisa com entrevistas semi estruturadas, na qual conversava sobre temas diversos com as crianças, tais como família e programas de televisão. O assunto específico de raça precisou ser introduzido pela pesquisadora para que as crianças verbalizassem, 
apesar de ser observado como forma ofensiva entre os grupos de crianças durante os momentos de recreação. A pesquisadora também levou materiais ilustrativos como uma revista sobre a cultura negra e um livro com a estória do folclore brasileiro sobre o "negrinho do pastoreio", com o objetivo de levantar as percepções das crianças ante a personagens ou pessoas negras. Como etapa final a pesquisadora selecionou dentre as crianças que estavam participando da pesquisa aquelas com idade entre oito e nove anos e propôs entrevistas, porém utilizando um ambiente mais lúdico, representado por dois conjuntos de sete bonecos e bonecas com cores diferentes, de forma que as crianças também poderiam brincar com os bonecos enquanto conversavam com a pesquisadora.

Um estudo clássico utilizando brinquedos foi realizado na década de 40 por Kenneth Clark (1963) em uma pesquisa na qual mostrava bonecas negras e brancas para crianças solicitando que elas indicassem com qual preferiam brincar, mostrando assim que as bonecas brancas tinham a preferência, mesmo para as crianças negras, o que denota uma deturpação na auto imagem da criança negra. Nos anos 2000, o cineasta Kiri Davis recriou o teste em formato de vídeo, que, atualmente, foi replicado em várias cidades do continente americano, inclusive no Brasil, gerando uma série de vídeos amplamente divulgados em redes sociais de comunicação pela internet. Todos os vídeos trazem em comum a preferência das crianças por brincar com as bonecas brancas, atribuindo a essas bonecas características mais positivas no tocante à beleza e à bondade. Porém é necessário verificar que os vídeos apesar de mostrarem uma situação bastante condizente com o que se observa de maneira cotidiana, carecem de rigor científico para validar seu método, de forma que não sabemos sobre o contexto em que o teste foi aplicado ou sobre o contexto das crianças em que o teste foi aplicado, também observa-se que apesar de semelhantes quanto a forma as bonecas apresentam vestimentas diferentes, o que pode interferir na escolha das crianças. O teste realizado no Brasil por Martins (2006) ilustra bem essas características, pois apesar de a maioria das crianças escolher a boneca branca, muitas vezes a justificativa advém de ela possuir um cabelo maior ou a roupa mais bonita. Independentemente do rigor científico com o qual o teste foi realizado, aponta para dados que validam a pesquisa de Clark (1988) mesmo com mais de 70 anos após sua realização.

Relacionando as pesquisas apresentadas até aqui, com destaque para a pesquisa de Fazzi (2009) e para os estudos elaborados a partir da pesquisa de 
Clark, destaco a importância de inserir o ambiente lúdico na pesquisa com crianças, concordando com a necessidade da ênfase para a interpretação dos dados a partir da ótica infantil, o que se coloca como uma dificuldade metodológica para as pesquisas dado a representação social que o adulto possui para a criança e a dificuldade que o próprio pesquisador possui para interpretar dados a luz do pensamento infantil.

Para a revisão bibliográfica também foi importante conhecer as pesquisas recentes que realizaram uma aproximação dos estudos produzidos por Adorno et al. (1965) em A personalidade Autoritária inclusive com adaptação da escala F elaborada no estudo, para facilitar a elaboração do instrumento a ser utilizado nesta pesquisa. Não foram localizadas pesquisas que realizaram a aplicação ou adaptação da escala $F$ para crianças na primeira infância. Já para sujeitos de pesquisa adultos, foram encontradas algumas replicações e adaptações da Escala F, geralmente coordenadas pelo o professor José Leon Crochík. Tal como a pesquisa de Crochík (2004) que aplica a escala de manifestação de preconceitos em estudantes do primeiro ano de cursos universitários da cidade de São Paulo. A pesquisa realizada por Pedrossian, Crochík, Meneses, Morais, Lima e Costa, Samper, Superti, Oliveira e Custódio (2008) também utilizou a aplicação das escalas de manifestação de preconceito, escala da ideologia da racionalidade tecnológica, escala de atitudes com relação à educação inclusiva e escala do fascismo (escala F) em acadêmicos do curso de licenciatura de duas diferentes universidades com o objetivo de verificar a atitude dos alunos de licenciatura com relação à educação inclusiva e suas correlações com as manifestações de preconceito, ideologia da racionalidade tecnológica e adesão ao fascismo.

A partir destes levantamentos sobre as pesquisas atuais relacionadas ao preconceito e suas expressões na infância, observa-se que é consenso entre os autores a existência do preconceito já na infância e a influência dos adultos na transmissão de valores sociais, já há muito arraigados, para as crianças. Outro dado que se mostra frequente é o fato de que crianças mais novas ainda não internalizaram normas sociais e tendem a explicitar o preconceito de maneira mais direta. Esta pesquisa se propõe a investigação a partir dos dados observados, visando identificar elementos do preconceito em crianças mais novas. Como instrumento de pesquisa empírica encontrou-se a utilização de questionários, fotografias, discussão em grupos e resolução de situações problemas; a intenção 
nesta pesquisa em utilizar um instrumento que seja direcionado pela brincadeira tem como objetivo ingressar mais diretamente no mundo da criança e com isso obter respostas mais fidedignas ao cotidiano e a forma como elas atuariam em situações de preconceito, tendo em vista que a criança utiliza o brincar para se comunicar.

Finda essa revisão bibliográfica, espera-se ter constituído subsidio teórico para a discussão sobre a pesquisa de campo que se propõe a partir deste ponto. 


\section{Objetivos e hipóteses da pesquisa}

Crianças com idade entre três e quatro anos reagem a situações cotidianas, durante o brincar, com respostas nas quais se podem identificar manifestações potencialmente preconceituosas?

Objetivo 1: investigar os itens sobre potencial de adesão ao preconceito tal qual o proposto na escala $\mathrm{F}$ : convencionalismo, submissão à autoridade, agressividade autoritária, identificação com figuras de poder e crença de que o mundo pode submeter à castigos; em crianças com idades entre três e quatro anos, adaptando a avaliação das situações para o momento do brincar.

Hipótese 1: serão encontrados elementos que denotam a presença destes itens com resultados elevados no momento do brincar das crianças.

Objetivo 2: no caso de encontrar, no momento do brincar, atribuição de papéis diferenciados que denotem possíveis manifestações de preconceito para os personagens de diferentes cor de pele ou para personagens com e sem deficiência, verificar se há possibilidade de alteração dos papéis atribuídos com a intervenção do adulto.

Hipótese 2: mesmo ante a intervenção do adulto no momento do brincar não haverá alteração dos papéis atribuídos na brincadeira pois as crianças já adotam como imutável a proposição social que observam no meio em que vivem.

Objetivo 3: caso sejam observadas manifestações do preconceito ou reprodução dos papéis preconceituosos atribuídos socialmente dadas às deficiências ou à cor da pele, verificar diferenças encontradas em estudantes que possuem contato com os grupos de pessoas negras ou com pessoas com deficiência e os grupos que não possuem contato.

Hipótese 3: espera-se que os estudantes que possuem contato em sala de aula com a diversidade na cor da pele e/ou com as pessoas com deficiência apresentem menor índice de manifestação do preconceito, desde que o contato entre as crianças tenha sido mediado por adultos que já trabalhem com a necessidade de minimizar o preconceito direcionado contra determinados grupos sociais. Caso o contato entre as crianças tenha acontecido sem nenhum tipo de mediação no cotidiano, não 
haverá diferença nos índices de manifestação do preconceito entre os estudantes que possuem e os que não possuem contato com crianças de cor de pele negra e ou com deficiência física.

\section{Método}

\subsection{Sujeitos}

Os sujeitos da pesquisa foram 37 alunos com idade entre três e quatro anos, de ambos os sexos, que estudavam na educação infantil, em uma escola da rede privada de ensino do município de São Paulo. Os alunos da escola são crianças pertencentes à classe socioeconômica definida como de padrão médio a alto, conforme informações cedidas pela coordenação pedagógica da escola. O que condiz com o índice de desenvolvimento humano (IDH) no valor de 0,863 calculado para o distrito no qual a escola se encontra localizada e declarado no atlas municipal elaborado pela prefeitura de São Paulo no ano de 2007 e disponível no site oficial da prefeitura.

Ainda de acordo com informações cedidas pela coordenação pedagógica da escola, há a presença de alunos com deficiência, sendo que a maioria possui deficiência não especificada devido à dificuldade de diagnóstico fechado dado a pouca idade das crianças. Algumas das crianças com deficiência são acompanhadas por terapeutas durante sua permanência na escola. Com relação à presença de crianças negras, segundo a coordenação há apenas duas crianças negras na escola, nenhuma delas na faixa etária pesquisada. Há professoras negras na escola e não há professoras com deficiência na escola. Quanto ao contato com a diferença relacionada à cor de pele e presença ou ausência de deficiência, a coordenadora declara que há um trabalho com as crianças sobre diversidade, oferecendo brinquedos que simbolizam pessoas com deficiência ou a variedade étnica (negros, brancos, índios, japoneses, ruivos) e busca-se uma seleção de histórias ou livros que favoreçam a diversidade.

As crianças participantes da pesquisa foram estudantes de quatro salas de aula distintas, sendo duas no período do matutino e duas no período vespertino. Em uma das salas de aula participante do período vespertino estuda uma criança diagnosticada com transtorno do espectro do autismo e possui acompanhamento de 
uma professora auxiliar com objetivo de favorecer sua comunicação com as demais crianças nos momentos de sala de aula, bem como auxiliar na adaptação e execução de tarefas pedagógicas, essa sala de aula será denominada como sala de aula A e contou com a participação de nove crianças. A outra sala de aula do período vespertino teve a participação de oito crianças e não conta com a presença de crianças com deficiência ou negras, e será denominada como sala de aula B. Designa-se por sala de aula C uma turma do período matutino sem a presença de pessoas com deficiência ou negras e desta sala de aula participaram da pesquisa 10 crianças. Por fim, participou da pesquisa o grupo que chamaremos de sala de aula D com 10 crianças e dentre estas a professora declara que há duas crianças com atraso no desenvolvimento não especificado, mostrando dificuldades acentuadas na fala e na compreensão das tarefas a ser executadas e nesta sala de aula há também a presença de uma professora negra. Sendo assim, formou-se uma subdivisão de dois grupos identificados como grupo AD formado por 19 crianças sujeitos da pesquisa que possuem contato em sala de aula com crianças com deficiência ou com a cor de pele negra; e o grupo BC formado por 18 crianças que não possuem contato em sala de aula com crianças com deficiência ou com a cor de pele.

Esta pesquisa foi submetida ao comitê de ética e pesquisa em seres humanos e aprovada em julho de 2015, sendo que a coleta de dados ocorreu nos meses de agosto e setembro deste mesmo ano. Foi solicitado à escola a assinatura da carta de anuência para que a realização da pesquisa no ambiente e horário de aula em que frequentam a escola. Os pais das crianças participantes receberam uma circular via comunicação da escola que explicou os objetivos da pesquisa e foi apresentado o termo de consentimento livre e esclarecido conforme constante nos apêndices. Com o intuído de preservar os sujeitos de pesquisa participantes, expressos tanto pelas crianças estudantes, quanto pela própria instituição escolar, será mantido rigoroso sigilo referente à identificação dos participantes da pesquisa, para que eles não sejam estigmatizados ou julgados a partir do resultado para o qual a pesquisa apontará. Após a avaliação dos resultados e finalização da pesquisa, será fornecido à escola uma cópia da tese, bem como será realizada uma reunião com a diretoria e com a coordenação pedagógica da escola, com o objetivo de discutir os resultados apurados e levantar possíveis formas de auxiliar no 
desenvolvimento de um trabalho que minimize a formação do preconceito em caso de a pesquisa apontar para altos índices de preconceito entre as crianças, ou de ampliar e consolidar a não formação de preconceito, no caso de a pesquisa apontar para baixos índices de preconceito entre as crianças. Em caso de diferenças notórias na formação do preconceito entre as salas, a reunião com a escola terá o objetivo de identificar o que leva a tais diferenças, discutindo propostas que contemplem uma educação com vistas a minimizar a constituição do preconceito para todas as crianças.

\subsection{Instrumento}

O instrumento da pesquisa tem base na escala F, elaborada por Adorno, Brunswik, Levinson e Sanford (1965) para verificar o potencial de autoritarismo presente nos indivíduos, com a intenção de replicar os estudos dirigidos com a aplicação da escala $\mathrm{F}$, porém em um público infantil. Como o público da pesquisa é composto por crianças, as situações propostas na escala $F$ por meio de perguntas foram remontadas de forma aproximada a partir da proposta de uma brincadeira do tipo jogo simbólico. Freud (1920) aponta que a criança compreende a realidade ao seu redor utilizando a brincadeira e a repetição desse ato de brincar, assim com a proposição de uma situação de brincadeira para a criança, espera-se que ela possa representar as possíveis características investigadas pela escala $\mathrm{F}$ quando aplicada aos adultos. Fazzi (2009) lembra da necessidade de se reproduzir um ambiente infantil para que a criança possa expressar seu pensamento, o que também deve ser interpretado à luz da realidade da criança, propondo que se minimize a interferência do pesquisador adulto durante o momento da coleta de dados.

Ao fornecer brinquedos e brincadeira para a criança também é oferecida a ela uma possibilidade de compreender de forma concreta as perguntas e de responder de acordo com a sua forma de expressão mais usual, que se dá menos com a utilização da linguagem oral e mais pela representação no brincar, conforme o proposto por Freud (1920). É necessário concretizar as situações em que se pode manifestar o preconceito, ou seja, no caso construir brinquedos que representem grupos potencialmente vítimas do preconceito. Para tanto foram escolhidos dois grupos historicamente compreendidos como focos do preconceito para o estudo, que são as pessoas negras e as pessoas com deficiências. A escolha dos grupos se deu pela facilidade em representá-los com a construção dos bonecos e pela 
possibilidade de convivência e de compreensão das crianças da diversidade expressa por esses grupos. Pode-se questionar aqui que a construção da escala $F$ teve como propósito medir os índices de preconceito nos indivíduos e para isso utilizaram perguntas que não identificavam diretamente atitudes que denotassem preconceitos contra grupos de minorias específicos (Adorno et al, 1965), e a escolha nesta pesquisa por bonecos que caracterizam grupos historicamente excluídos, seria então justamente ao contrário da proposta na construção da escala $F$. A explicação para tal escolha se justifica no fato de que crianças pequenas ainda não internalizaram normas sociais do que pode ou não ser falado em público, tendendo a explicitar mais diretamente atitudes de diferenciação ante a grupos excluídos, conforme os achados na pesquisa de França e Monteiro (2004). Também pode-se dizer que a atribuição de papéis sociais a um determinado grupo representado pelos bonecos não diz respeito a uma demonstração de preconceito por parte da criança, mas sim a uma representação simbólica da realidade na qual a criança vive. Esse tipo de representação será observado sob a justificativa de que é desde a primeira infância que a criança começa a construir as representações sociais com as quais atuará na vida adulta.

\subsubsection{Divisão em grupos das crianças pesquisadas}

Como já especificado na descrição dos sujeitos de pesquisa, as crianças pesquisadas foram subdivididas em dois grupos, classificados como:

GRUPO AD - crianças sem contato na sala de aula com pessoas que representam a diversidade de cor de pele e de deficiências.

GRUPO BC - crianças com contato na sala de aula com pessoas que representam a diversidade de cor de pele e de deficiências.

A proposição em dividir as crianças pesquisadas em grupos visa responder ao objetivo três da pesquisa, compreendendo se a experiência com crianças pertencentes aos grupos socialmente vitimas do preconceito levam a menos manifestações de preconceito pelas crianças.

\subsubsection{Observação lúdica}

Após a observação do pré teste da representação lúdica, conforme descritos nos subitens abaixo, e respeitando os apontamentos discutidos durante a qualificação desta pesquisa, verificou-se a necessidade de observar a criança no 
brincar sem a interferência do adulto, com a intenção de observar como elas escolhem os brinquedos propostos e como o grupo de crianças se auto regula ante a situações em que tenham de brincar com bonecos que representem grupos potencialmente vítimas do preconceito. Tal importância está em consonância com a proposição metodológica para o trabalho com crianças elaborada por Fazzi (2004), no qual intenciona neutralizar as interferências dos adultos para observar a relação das crianças ante as noções de diferenças raciais, entendendo que as relações que as crianças estabelecem entre si são tão ou mais importantes que as relações que estabelecem com outros agentes socializadores.

Sendo assim, a pesquisadora disponibilizou os bonecos para que grupos de aproximadamente cinco crianças pudessem brincar sem a interferência do adulto. À pesquisadora coube observar a forma de interação das crianças entre si e das crianças com os brinquedos, num tempo estimado de dez minutos. Tais observações foram anotadas e descritas com as falas das crianças e forma como brincam com os materiais com o intuito de auxiliar qualitativamente na análise do material obtido com a representação lúdica.

\subsubsection{Representação lúdica}

Em um espaço oferecido pela escola foi conduzida pela pesquisadora, com cada criança sujeito da pesquisa de maneira individual, uma brincadeira de jogo simbólico de casinha. Para tanto foram apresentados à criança 16 bonecos de pano representando:

- Um homem, uma mulher, um menino e uma menina brancos e sem deficiências.

- Um homem, uma mulher, um menino e uma menina negros e sem deficiências

- Um homem, uma mulher, um menino e uma menina brancos, todos com amputação de membro inferior.

- Um homem, uma mulher, um menino e uma menina negros, todos com amputação de membro inferior.

Os bonecos estiveram dispostos de forma aleatória para não caracterizar uma família já pré-estabelecida e foram espalhados para garantir que a criança pudesse visualizar todas as possibilidades de escolhas. Segue abaixo fotografia dos bonecos produzidos e utilizados especialmente nesta pesquisa: 

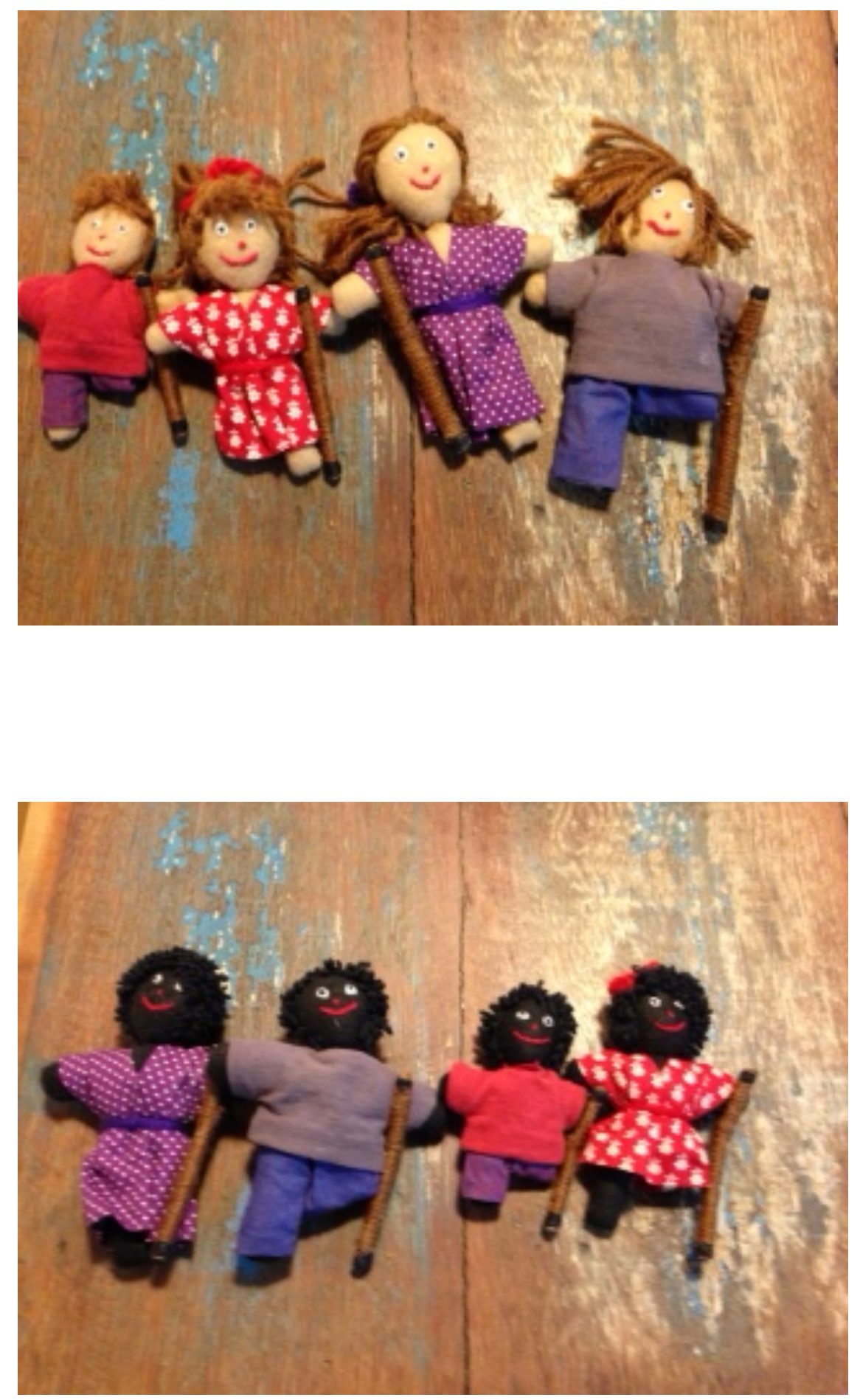

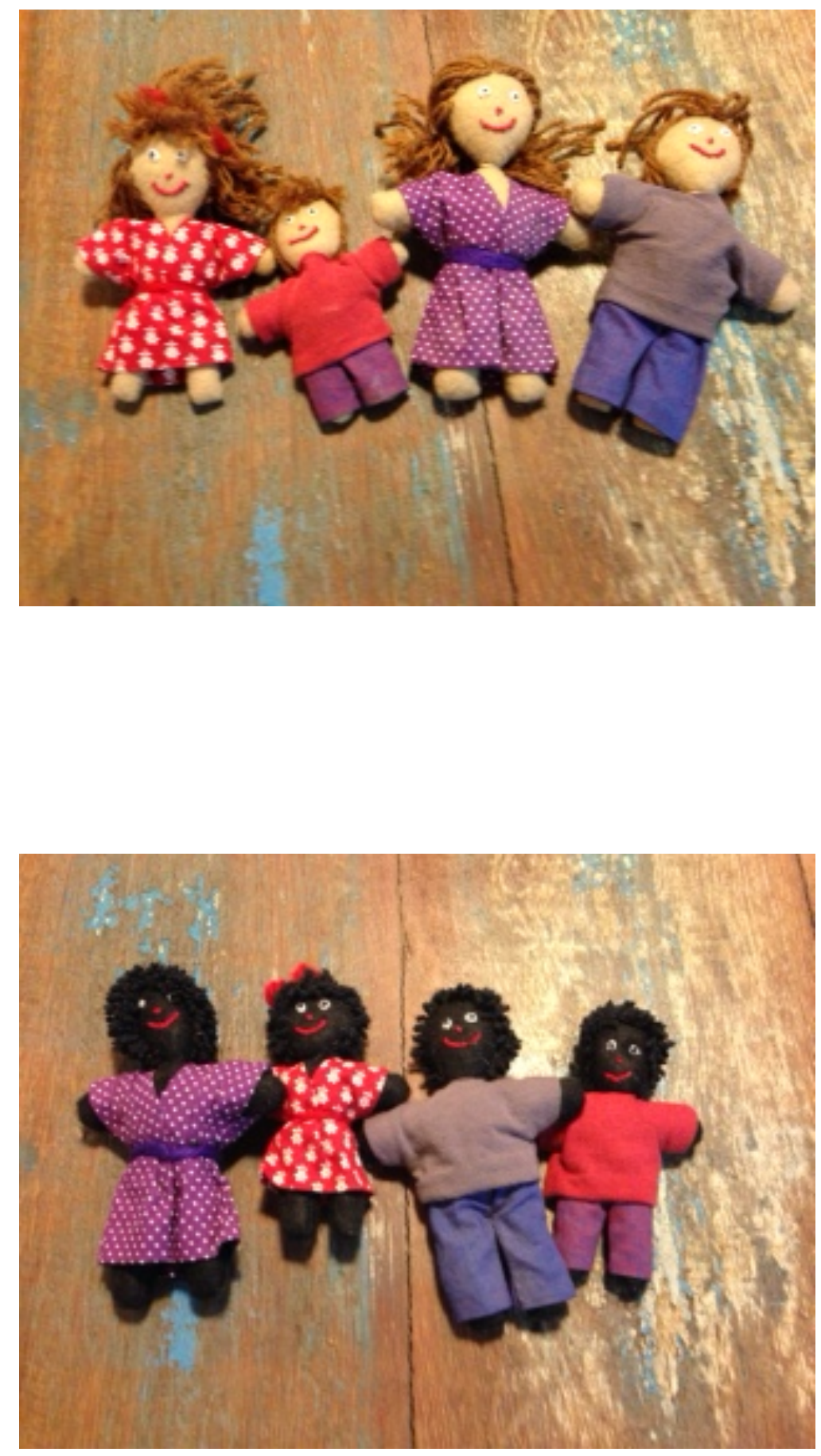


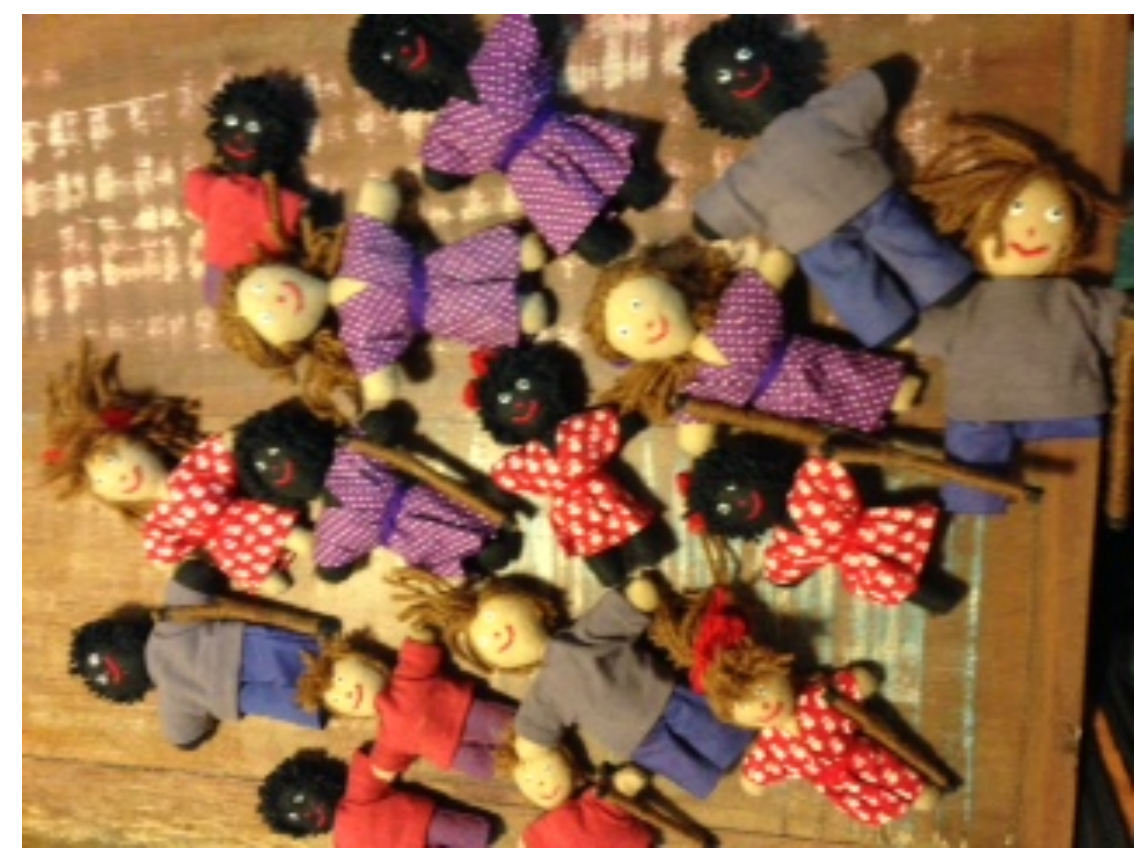

fotografias de autoria da própria pesquisadora

A brincadeira foi direcionada pela pesquisadora que explicou às crianças que fariam uma brincadeira de casinha e que a criança primeiro teria de escolher dois bonecos para cuidar das crianças e dois bonecos para que representem os filhos, um boneco para representar a ajudante da casa e um boneco para representar o filho dessa ajudante. Nesse momento outros personagens não poderiam ser escolhidos, mas durante a brincadeira a criança pode colocá-los para brincar junto.

A escolha dos padrões familiares foi a primeira situação problema proposta para a criança, a partir desta escolha foram expostas outras situações problema e observadas as reações da criança durante o brincar:

Situação 2 - Escolha de um dos personagens criança para derrubar o aparelho celular de um dos personagens que representa um adulto cuidador.

Situação 3 - Seleção da punição para o personagem que representa a criança que derrubou o aparelho celular, averiguação de concordância com a punição e de capacidade de resignação ante esta.

Situação 4- Seleção de um dos personagens para realizar uma produção escolar reconhecida pelos adultos.

Situação 5 - Determinação de punição para um personagem que representa um filho que desobedece aos pais.

Situação 6 - Determinação de punição para o personagem filho do ajudante que o desobedece. 
Situação 7 - Escolha de atitudes que os personagens que representam crianças devem tomar com relação a outras crianças que têm comportamentos considerados errados pelos adultos.

Situação 8 - Averiguar os papéis que cada boneco que representa uma criança assume na representação de uma brincadeira entre as crianças.

Situação 9 - Inserção de um personagem com deficiência ou negro em situação de vantagem, caso esse não tenha sido previamente escolhido dessa forma pela criança e análise da atribuição do papel que a criança dará.

As situações foram apresentadas na forma de representação lúdica para a criança, segue abaixo um quadro que apresenta o roteiro aproximado com a forma de como conduzir a brincadeira, para facilitar a visualização; as atitudes que foram propostas para a criança estão destacadas em negrito.

Quadro I - forma de proposição da representação lúdica para os sujeitos da pesquisa.

Pesquisador- Nós temos aqui esses bonecos para brincarmos e quero que juntos vamos montando uma história de um dia na vida dessas pessoas. Primeiro eu preciso que você escolha dois adultos para representar quem cuida das crianças quando elas estão na casa delas.

Criança escolhe sem intervenção do pesquisador.

Pesquisador - agora vamos escolher outros dois bonecos para as crianças.

Criança escolhe sem intervenção do pesquisador.

Pesquisador- vamos escolher alguém para trabalhar na casa também, vai ajudar na limpeza da casa e a cuidar das crianças quando os pais estão no trabalho.

Criança escolhe sem intervenção do pesquisador.

Pesquisador- ah, e vamos escolher também alguém pra ser filho ou filha de quem ajuda na limpeza da casa.

Criança escolhe sem intervenção do pesquisador.

A partir daqui começa a representação lúdica por parte da criança e da pesquisadora.

Pesquisadora pega um dos bonecos que representa o adulto cuidador e fala - quem foi que deixou meu celular cair no chão? Agora está tudo quebrado! - pede para que a criança escolha um dos bonecos para ser o responsável e representar o que aconteceria.

Pesquisadora se dirige ao outro boneco representante do cuidador adulto e reproduz conversa entre os dois cuidadores - Ele não podia ter feito isso, é bem errado! $O$ 
que vamos fazer com ele agora? - pede para que a criança faça a fala de um dos cuidadores e dê um solução para lidar com a criança que quebrou o telefone. Pesquisadora pega o boneco que representa a outra criança que não foi punida e pergunta se a criança escolhida para quebrar o celular concorda com o castigo e se irá obedecer.

Pesquisadora com o boneco que representa o adulto cuidador fala- Mas olha só, também tenho boas notícias, olha que desenho bonito esse desenho que eu peguei da escola, adivinha quem fez? - pede para que a criança escolha um dos bonecos que representa a criança para ter feito o desenho.

Pesquisador ainda com o boneco que representa o adulto cuidador fala para o outro adulto cuidador- precisamos dar um jeito nessa criança (pega o boneco escolhido pela criança para quebrar o celular), você acredita que ele foi muito mal educado comigo, tentou me bater e falou coisa feia! - pede para criança pegar o outro adulto e escolher o que deve ser feito com o filho desobediente.

Pesquisador pega o boneco que representa o ajudante e diz - Ah é assim mesmo, meu filho também foi muito mal educado comigo, o que você acha que eu devo fazer? - pede para que a criança pegue um dos adultos e escolha o que deve ser feito com o filho do ajudante que desobedeceu.

Pesquisador pega aleatoriamente um dos bonecos que representa os filhos e começa a propor quebrar coisas, brigar com as outras crianças, mostrar a língua, pede para que a criança represente os outros dois bonecos selecionados para serem crianças e faça com que eles interajam.

Pesquisadora sugere que a criança crie uma brincadeira para todas os bonecos que representem crianças, enquanto ela levará os adultos para o trabalho.

Caso a criança não tenha selecionado um boneco que represente a criança com deficiência ou a criança negra, pegar um desses bonecos e pedir para que ele também brinque, fornecendo o modelo de colocar esse boneco em vantagem social.

As situações problemas foram propostas com base na Escala $F$ elaborada por Adorno, Brunswik, Levinson e Sanford (1965), com a intenção de identificar o potencial de autoritarismo e adesão ao fascismo presente nos indivíduos que não se declaravam fascistas. A escala $F$ passou por várias revisões, chegando a uma forma 
final composta por 29 questões que se propuseram a identificar os seguintes aspectos:

- Índice de adesão aos valores impostos pela classe média, o que foi denominado como convencionalismo.

- Submissão à autoridade.

- Necessidade de controlar os indivíduos que não se submetem aos valores convencionais utilizando a agressividade, o que denominou de agressividade autoritária.

- Posição de oposição à manifestação dos sentimentos e de valores subjetivos.

- Crença em poderes sobrenaturais.

- Identificação com as figuras que representam o poder e necessidade de se submeter a estas.

- Hostilidade com a humanidade.

- Crença de que o mundo pode submeter a castigos, ou mesmo projeção dos impulsos destrutivos inconscientes.

- Preocupação exagerada com os impulsos sexuais.

As questões foram elaboradas de forma não diretiva e dispostas de maneira intercalada durante o questionário, com a finalidade de que as pessoas não identificassem o padrão de respostas preconceituosas e as evitassem. Para a avaliação foi elaborada um padrão de escala de respostas do tipo likert, no qual foram atribuídos pontos crescentes conforme as opções de resposta para cada item. Quão maior a pontuação, maior o índice de adesão ao fascismo presente no sujeito da pesquisa.

Para produzir uma brincadeira que levasse em conta os itens avaliados pela escala $F$, foi necessário adaptar as perguntas para as situações problema expostas durante a brincadeira, de maneira que cada situação problema foi atribuída a um dos itens que representa como tema central, estabelecendo a correlação conforme o quadro II : 
Quadro II - relação entre itens medidos pela escala F e elaboração de situações problema da representação lúdica.

\begin{tabular}{|c|c|}
\hline Itens avaliados pela Escala F & Situação problema correspondente \\
\hline Convencionalismo & $\begin{array}{l}\text { Situação } 1 \text { - escolha dos } \\
\text { personagens } \\
\text { Situação } 2 \text { - escolha de personagem } \\
\text { para derrubar aparelho celular. } \\
\text { Situação 4- Seleção de um dos } \\
\text { personagens para realizar uma } \\
\text { produção escolar reconhecida pelos } \\
\text { adultos. } \\
\text { Situação } 8 \text { - Averiguar os papéis que } \\
\text { cada boneco que representa uma } \\
\text { criança assume na representação de } \\
\text { uma brincadeira entre as crianças. } \\
\text { Situação } 9 \text { - Inserção de um } \\
\text { personagem com deficiência ou } \\
\text { negro em situação de vantagem, } \\
\text { caso esse não tenha sido } \\
\text { previamente escolhido dessa forma } \\
\text { pela criança e análise da atribuição } \\
\text { do papel que a criança dará. }\end{array}$ \\
\hline Submissão à autoridade & $\begin{array}{l}\text { Situação } 3 \text { - Seleção da punição } \\
\text { para o personagem que representa a } \\
\text { criança que derrubou o aparelho } \\
\text { celular, averiguação de concordância } \\
\text { com a punição e de capacidade de } \\
\text { resignação ante esta. }\end{array}$ \\
\hline Agressividade autoritária & $\begin{array}{l}\text { Situação } 5-\text { Determinação de } \\
\text { punição para um personagem que } \\
\text { representa um filho que desobedece }\end{array}$ \\
\hline
\end{tabular}




\begin{tabular}{|l|l|}
\hline Identificação com figuras de poder & $\begin{array}{l}\text { Situação } 6 \text { pais. } \\
\text { punição para o personagem filho da } \\
\text { ajudante que a desobedece. }\end{array}$ \\
\hline $\begin{array}{l}\text { Crença de que o mundo pode } \\
\text { submeter a castigos }\end{array}$ & $\begin{array}{l}\text { Situação 7 - Escolha de atitudes que } \\
\text { os personagens que representam } \\
\text { crianças devem tomar com relação a } \\
\text { outras crianças que têm } \\
\text { comportamentos } \\
\text { errados pelos adultos. }\end{array}$ \\
\hline
\end{tabular}

Destaca-se que o item de crença em poderes sobrenaturais não pode ser medido em crianças de três a quatro anos de idade, pois segundo Freud (1905) elas estão em processo de constituição de autonomia psíquica e é esperado que a criança acredite que existe uma força maior que ela capaz de tomar decisões, tendo em vista que ela não constitui suas próprias regras. Também as medidas propostas na escala $F$ sobre preocupação exagerada com a sexualidade, oposição à manifestação de sentimentos e hostilidade com a humanidade, não podem ser avaliadas porque a criança ainda não desenvolveu a percepção integral do outro, ocupando posição autocentrada.

A escala elaborada foi apresentada a três juízes formados por psicólogos, com vistas a comprovar sua validade, conforme o preenchimento da ficha constante no apêndice III. As respostas dos juízes estão tabuladas no quadro abaixo: 
Quadro III- tabulação da avaliação dos juízes sobre as situações problema propostas na representação lúdica e o índice que correspondem na escala F.

\begin{tabular}{|c|c|c|c|c|}
\hline $\begin{array}{l}\text { Itens avaliados pelas } \\
\text { escala F }\end{array}$ & $\begin{array}{l}\text { Situações } \\
\text { problema } \\
\text { propostas pelo } \\
\text { Juiz 1- } \\
\text { psicólogo, } \\
\text { doutorando, } \\
\text { referencial } \\
\text { teórico Teoria } \\
\text { Crítica }\end{array}$ & $\begin{array}{l}\text { Situações } \\
\text { problema } \\
\text { propostas pelo } \\
\text { Juiz } 2 \text { - } \\
\text { psicólogo, } \\
\text { graduado, } \\
\text { referencial } \\
\text { teórico } \\
\text { Psicanálise }\end{array}$ & $\begin{array}{l}\text { Situações } \\
\text { problema } \\
\text { propostas pelo } \\
\text { Juiz } \\
\text { psicólogo, } \\
\text { doutorando, } \\
\text { referencial } \\
\text { cognitivista }\end{array}$ & $\begin{array}{l}\text { Elaboração } \\
\text { inicial na } \\
\text { pesquisa }\end{array}$ \\
\hline convencionalismo & $1,4,7,8$ e 9 & $2,3,4,8$ e 9 & 1,2 & $1,2,4,8$ e 9 \\
\hline $\begin{array}{l}\text { Submissão } \quad \text { a } \\
\text { autoridade }\end{array}$ & 3,5 e 6 & 3 e 9 & 3 e 4 & 3 \\
\hline $\begin{array}{l}\text { Agressividade } \\
\text { autoritária }\end{array}$ & $3,5,6$ e 7 & $5,6,7$ e9 & 3 e 6 & 5 \\
\hline $\begin{array}{l}\text { Identificação com } \\
\text { figuras de poder }\end{array}$ & $2,5,6$ e 3 & 7 e 9 & 4,5 e 6 & 6 \\
\hline $\begin{array}{l}\text { Crença de que o } \\
\text { mundo pode } \\
\text { submeter } \\
\text { castigos }\end{array}$ & $7,3,5 \mathrm{e} 6$ & 3,5 e 6 & $3,5,6$ e 7 & 7 \\
\hline
\end{tabular}

Após comparar a versão elaborada pela pesquisadora da correlação entre os itens medidos pela escala $\mathrm{F}$ e as situações problema propostas na pesquisa com as respostas obtidas pelos juízes, convencionou-se que havendo um índice de concordância igual ou superior a dois terços conforme a seleção realizada pelos juízes, o índice seria incluso como situação problema utilizada para medir o item da escala $F$ que se intenciona avaliar. Assim chegou-se ao padrão final de correlação entre as situações problema e os itens medidos pela escala $\mathrm{F}$ conforme o descrito no quadro abaixo. 
Quadro IV - relação final entre itens medidos pela escala $F$ e elaboração de situações problema da representação lúdica.

\begin{tabular}{|l|l|}
\hline Itens avaliados pela Escala F & Situação problema correspondente \\
\hline Convencionalismo & $1,2,4,8$ e 9 \\
\hline Submissão à autoridade & 3 \\
\hline Agressividade autoritária & $3,5,6$ e 7 \\
\hline Identificação com figuras de poder & 5 e 6 \\
\hline $\begin{array}{l}\text { Crença de que o mundo pode } \\
\text { submeter a castigos }\end{array}$ & $3,5,6$ e 7 \\
\hline
\end{tabular}

Como na elaboração da escala $F$ foi proposto um tipo de avaliação das respostas padrão do tipo likert, houve a necessidade de elaborar um padrão de respostas e atribuir valores com o objetivo de criar uma escala para verificar as respostas com maior ou menor tendência ao preconceito fornecida pelas crianças. Para tanto foi realizado um pré teste com quatro crianças de ambos os sexos, com idades entre três e quatro anos. O objetivo do pré- teste foi averiguar a capacidade de entendimento da criança ante a situação proposta e a pertinência das situações propostas como possibilidades de resposta. A partir das respostas fornecidas pelas crianças foi possível estabelecer uma escala de possibilidades de respostas que poderiam ser fornecidas pelas crianças. Para o pré-teste foi solicitado anuência para participação aos pais da criança e verificado se a criança gostaria de participar. Todas as crianças participantes já eram conhecidas da pesquisadora e tiveram contato anterior com ela, o que facilitou o procedimento do pré-teste e que poderia se configurar como uma dificuldade na relação com os sujeitos de pesquisa, reforçando a necessidade de primeiramente observar as crianças em um momento de brincar livre e sem a intervenção do adulto antes de aplicar o procedimento da representação lúdica. O pré- teste foi aplicado em um consultório de atendimento psicológico a crianças, ambiente lúdico e preservado de interferências externas. Os resultados foram observados pela pesquisadora e depois anotados nos formulários 
de avaliação do pré teste. Segue no quadro abaixo a apresentação dos resultados obtidos no pré teste:

Quadro V: resultados obtidos no pré-teste.

\begin{tabular}{|c|c|c|}
\hline $\begin{array}{l}\text { Descrição } \\
\text { da } \\
\text { criança }\end{array}$ & Escolha da família & $\begin{array}{l}\text { Observações no momento } \\
\text { do brincar (comentários e } \\
\text { escolhas da criança) }\end{array}$ \\
\hline $\begin{array}{lr}\text { Menino } & \\
\text { branco } & \\
\text { com } & 4 \\
\text { anos de } & \\
\text { idade } & \end{array}$ & $\begin{array}{l}\text { Cuidadores: mulher branca e } \\
\text { mulher branca com } \\
\text { deficiência. } \\
\text { Crianças: menino branco e } \\
\text { menino branco com deficiência } \\
\text { Ajudante: mulher negra e } \\
\text { mulher negra com deficiência }\end{array}$ & $\begin{array}{l}\text { 1)Comenta "eca" ao ver os } \\
\text { bonecos negros e quando } \\
\text { questionado explica que é } \\
\text { porque não gosta de coisas } \\
\text { pretas. } \\
\text { 2) como castigo sugere matar } \\
\text { as crianças sempre } \\
\text { 3) Escolhe bonecos negros } \\
\text { para realizar situações } \\
\text { consideradas erradas. }\end{array}$ \\
\hline $\begin{array}{l}\text { Menino } \\
\text { oriental, } \\
\text { sexo } \\
\text { masculino, } \\
3 \text { anos e } \\
10 \text { meses } \\
\text { de idade }\end{array}$ & $\begin{array}{l}\text { Cuidadores: mulher branca e } \\
\text { homem negro. } \\
\text { Crianças: menino branco e } \\
\text { menino negro. } \\
\text { Ajudante: mulher branca com } \\
\text { deficiência e menina branca }\end{array}$ & $\begin{array}{l}\text { 1) Recusa a participação da } \\
\text { criança com deficiência } \\
\text { alegando que ela é como o } \\
\text { saci Pererê e ele é malvado. } \\
\text { 2) Não sugere punição para } \\
\text { as crianças. }\end{array}$ \\
\hline $\begin{array}{l}\text { Menina } \\
\text { branca, } 3 \\
\text { anos e } 2 \\
\text { meses de } \\
\text { idade }\end{array}$ & $\begin{array}{l}\text { Cuidadores: mulher branca e } \\
\text { mulher branca com } \\
\text { deficiência. } \\
\text { Crianças: menina branca e } \\
\text { menina branca com } \\
\text { deficiência. }\end{array}$ & $\begin{array}{l}\text { 1) Como punição escolhe } \\
\text { colocar a criança de castigo. } \\
\text { 2) Escolhe a criança negra } \\
\text { para cometer as atitudes que } \\
\text { considera erradas e a menina } \\
\text { branca para ser elogiada }\end{array}$ \\
\hline
\end{tabular}




\begin{tabular}{|c|c|c|}
\hline & $\begin{array}{l}\text { Ajudante: mulher negra e } \\
\text { menina negra. }\end{array}$ & pelos pais. \\
\hline $\begin{array}{l}\text { Menino } \\
\text { branco, } 3 \\
\text { anos e } 11 \\
\text { meses de } \\
\text { idade. } \\
\text { Criança } \\
\text { apresenta } \\
\text { atraso na } \\
\text { linguagem. }\end{array}$ & $\begin{array}{l}\text { Cuidadores: mulher branca e } \\
\text { homem negro. } \\
\text { Crianças: menina branca com } \\
\text { deficiência e menina negra } \\
\text { com deficiência. } \\
\text { Ajudante: homem negro com } \\
\text { deficiência e menina negra. }\end{array}$ & $\begin{array}{l}\text { 1) Explica que os pais } \\
\text { descobrirão que a filha } \\
\text { quebrou o celular e tirarão o } \\
\text { computador dela. } \\
\text { 2) coloca todas as crianças } \\
\text { brincando juntas e atribui a } \\
\text { todas elas a culpa de quebrar } \\
\text { o celular. }\end{array}$ \\
\hline
\end{tabular}

A aplicação do pré teste foi realizada em um tempo que variou entre dez e quinze minutos, as crianças aceitaram participar da brincadeira sem relutância e mostraram compreender a proposta, conseguindo responder as situações problemas apresentadas de forma adequada. O reconhecimento das diferenças entre os bonecos representadas pela tonalidade da pele e pela presença ou ausência de deficiência ocorreu com todos os participantes do pré-teste.

Após a realização do pré-teste, foi elaborada uma primeira escala de padrões possíveis de respostas das crianças com a respectiva pontuação que gradua de zero a cinco pontos, sendo que a atribuição zero indica menor índice de demonstração de comportamento preconceituoso e a atribuição cinco o maior índice. O quadro VI descrito abaixo demonstra a distribuição dos pontos conforme as possibilidades de respostas para as situações problema: 
Quadro VI: escala de pontuação para respostas a situações problema propostas na representação lúdica

\begin{tabular}{|c|c|}
\hline Situação problema & Padrão de resposta e pontuação \\
\hline $\begin{array}{lr}\text { Situação } & 1 \\
\text { escolha dos } & \text { papéis } \\
\text { para } & \text { os } \\
\text { personagens } & \end{array}$ & $\begin{array}{l}\text { (0) personagens de etnias diferentes na mesma família, } \\
\text { incluindo ou não a presença de pelo menos um } \\
\text { personagem com deficiência. } \\
\text { (1) escolha de todos os personagens da mesma etnia, } \\
\text { ou todos apresentando ou não deficiência. } \\
\text { (2) escolha de personagens exclusivamente negros para } \\
\text { família e personagens exclusivamente brancos para } \\
\text { ajudantes, com presença de pelo menos um } \\
\text { personagem com deficiência. } \\
\text { (3) escolha de personagens exclusivamente brancos } \\
\text { para a família e personagens exclusivamente negros } \\
\text { para ajudantes, com presença de pelos menos um } \\
\text { personagem com deficiência. } \\
\text { (4) escolha de personagens exclusivamente negros para } \\
\text { família e personagens exclusivamente brancos para } \\
\text { ajudantes, sem presença de pelo menos um } \\
\text { personagem com deficiência. } \\
\text { para a família e personagens exclusivamente negros } \\
\text { personagem com deficiência. }\end{array}$ \\
\hline $\begin{array}{l}\text { Situação } 2- \\
\text { Escolha de um dos } \\
\text { personagens } \\
\text { criança para } \\
\text { derrubar o aparelho } \\
\text { celular de um dos }\end{array}$ & $\begin{array}{l}\text { (0) - Criança branca } \\
\text { (1) - Criança negra } \\
\text { (2) Criança branca com deficiência } \\
\text { (3) Criança negra com deficiência }\end{array}$ \\
\hline
\end{tabular}




\begin{tabular}{|c|c|}
\hline $\begin{array}{ll}\text { personagens } & \text { que } \\
\text { representa } & \text { um } \\
\text { adulto cuidador. } & \end{array}$ & \\
\hline $\begin{array}{l}\text { Situação } \\
\text { Seleção da punição } \\
\text { para o personagem } \\
\text { que representa a } \\
\text { criança que } \\
\text { derrubou o aparelho } \\
\text { celular, } \\
\text { concordância e } \\
\text { obediência. }\end{array}$ & $\begin{array}{l}\text { (0) Não haverá punição. } \\
\text { (1) Conversar ou castigo, sem concordar ou obedecer. } \\
\text { (2) conversa ou castigo, concordando e sem obedecer. } \\
\text { (3) conversa ou castigo, concordando e obedecendo. } \\
\text { (4) Bater, sem concordar. } \\
\text { (5) Bater, com concordância. }\end{array}$ \\
\hline $\begin{array}{lr}\text { Situação } & 4- \\
\text { Seleção de } & \text { um dos } \\
\text { personagens } & \text { para } \\
\text { realizar } & \text { uma } \\
\text { produção } & \text { escolar } \\
\text { reconhecida } & \text { pelos } \\
\text { adultos. } & \end{array}$ & $\begin{array}{l}\text { (0) Criança negra com deficiência } \\
\text { (1) Criança branca com deficiência. } \\
\text { (2) Criança negra } \\
\text { (3) Criança branca. }\end{array}$ \\
\hline $\begin{array}{lr}\text { Situação } & - \\
\text { Determinação } & \text { de } \\
\text { punição para um } & \text { um } \\
\text { personagem } & \text { que } \\
\text { representa um filho } \\
\text { que desobedece } \\
\text { aos pais. }\end{array}$ & $\begin{array}{l}\text { (0) Não haverá punição. } \\
\text { (1) Conversar com a criança. } \\
\text { (2) Colocar a criança de castigo. } \\
\text { (3) Bater na criança } \\
\text { (4) Quebrar algo da criança } \\
\text { (5) Excluir o personagem da brincadeira }\end{array}$ \\
\hline \begin{tabular}{lr} 
Situação & \multicolumn{1}{c}{$\begin{array}{l}\text { o de } \\
\text { Determinação } \\
\text { punição para }\end{array}$} \\
personagem filho da & qudante que a
\end{tabular} & $\begin{array}{l}\text { (0) Não haverá punição. } \\
\text { (1) Conversar com a criança. } \\
\text { (2) Colocar a criança de castigo. }\end{array}$ \\
\hline
\end{tabular}




\begin{tabular}{|c|c|}
\hline desobedece. & $\begin{array}{l}\text { (3) Bater na criança } \\
\text { (4) Quebrar algo da criança } \\
\text { (5) Excluir o personagem da brincadeira } \\
\text { OBS - Incluir mais } 1 \text { ponto caso a punição escolhida } \\
\text { seja mais severa que a aplicada para situação } 5\end{array}$ \\
\hline $\begin{array}{l}\text { Situação } \\
\text { Escolha de atitudes } \\
\text { que os personagens } \\
\text { que representam } \\
\text { crianças devem } \\
\text { tomar com relação a } \\
\text { outras crianças que } \\
\text { tem } \\
\text { comportamentos } \\
\text { considerados } \\
\text { errados } \\
\text { adultos. }\end{array}$ & $\begin{array}{l}\text { (0) Não haverá punição. } \\
\text { (1) Conversar com a criança. } \\
\text { (2) Colocar a criança de lado na brincadeira. } \\
\text { (3) Bater na criança } \\
\text { (4) Fazer um grupo para excluir a criança. } \\
\text { (5) Excluir o personagem da brincadeira }\end{array}$ \\
\hline $\begin{array}{l}\text { Situação } 8 \\
\text { Averiguar os papéis } \\
\text { que cada boneco } \\
\text { que representa uma } \\
\text { criança assume na } \\
\text { representação de } \\
\text { uma brincadeira } \\
\text { entre as crianças. }\end{array}$ & $\begin{array}{l}\text { (0) Não há diferença entre papéis. } \\
\text { (1) Identificar como líder a criança do mesmo sexo que } \\
\text { o do sujeito de pesquisa. } \\
\text { (2) Identificar como líder crianças com deficiência. } \\
\text { (3) Identificar como líder crianças negras. } \\
\text { (4) Identificar como líder crianças brancas. } \\
\text { (5) Excluir algum personagem da brincadeira. }\end{array}$ \\
\hline $\begin{array}{lrr}\text { Situação } & 9 & - \\
\text { Inserção de } & \text { um } \\
\text { personagem } & \text { com } \\
\text { deficiência ou negro }\end{array}$ & $\begin{array}{l}\text { (0) Não há diferença entre os papéis. } \\
\text { (1) Cuidar do personagem. } \\
\text { (2) Colocar impossibilidades para o personagem. }\end{array}$ \\
\hline
\end{tabular}




\begin{tabular}{|l|l|}
\hline $\begin{array}{l}\text { em situação de } \\
\text { vantagem, caso }\end{array}$ & (3) Agredir física ou verbalmente o personagem. \\
esse não tenha sido & $\begin{array}{l}\text { (4) Aceitar o personagem, mas não incluí-lo na } \\
\text { brincadeira após a intervenção do pesquisador. }\end{array}$ \\
$\begin{array}{l}\text { previamente } \\
\text { escolhido dessa } \\
\text { forma pela criança e } \\
\text { análise da atribuição }\end{array}$ & (5) Recusar a participação do personagem. \\
$\begin{array}{l}\text { do papel que a } \\
\text { criança dará. }\end{array}$ & \\
\hline
\end{tabular}

Esta escala de pontuação elaborada foi também submetida a três juízes compostos por psicólogos, com as repostas apresentadas sem atribuição de valores e foi solicitado aos juízes que pontuassem, numa escala de 0 a 5 , de forma que 0 represente a situação potencialmente menos preconceituosa e 5 a situação potencialmente mais preconceituosa, conforme a ficha constante no apêndice III. A valoração dos juízes para as possibilidades de respostas fornecidas pelas crianças durante a aplicação das representação lúdica segue:

Quadro VII: escala de pontuação para respostas a situações problema propostas na representação lúdica

\begin{tabular}{|c|c|c|c|c|}
\hline $\begin{array}{l}\text { Situação } \\
\text { problema }\end{array}$ & $\begin{array}{l}\text { Juiz } \\
1\end{array}$ & $\begin{array}{l}\text { Juiz } \\
2\end{array}$ & $\begin{array}{l}\text { Juiz } \\
3\end{array}$ & Padrão de resposta e pontuação \\
\hline $\begin{array}{lr}\text { Situação } 1 & - \\
\text { escolha dos papéis } & \\
\text { para } & \text { os } \\
\text { personagens } & \end{array}$ & 0 & 1 & 0 & $\begin{array}{l}\text { - Personagens de cor diferentes na } \\
\text { mesma família, incluindo ou não a } \\
\text { presença de pelo menos um } \\
\text { personagem com deficiência. } \\
\text { - Escolha de todos os personagens } \\
\text { da mesma cor, ou todos } \\
\text { apresentando ou não deficiência. } \\
\text {-Escolha de personagens } \\
\text { exclusivamente negros para família } \\
\text { e personagens exclusivamente }\end{array}$ \\
\hline
\end{tabular}




\begin{tabular}{|c|c|c|c|c|}
\hline & 5 & 5 & 5 & 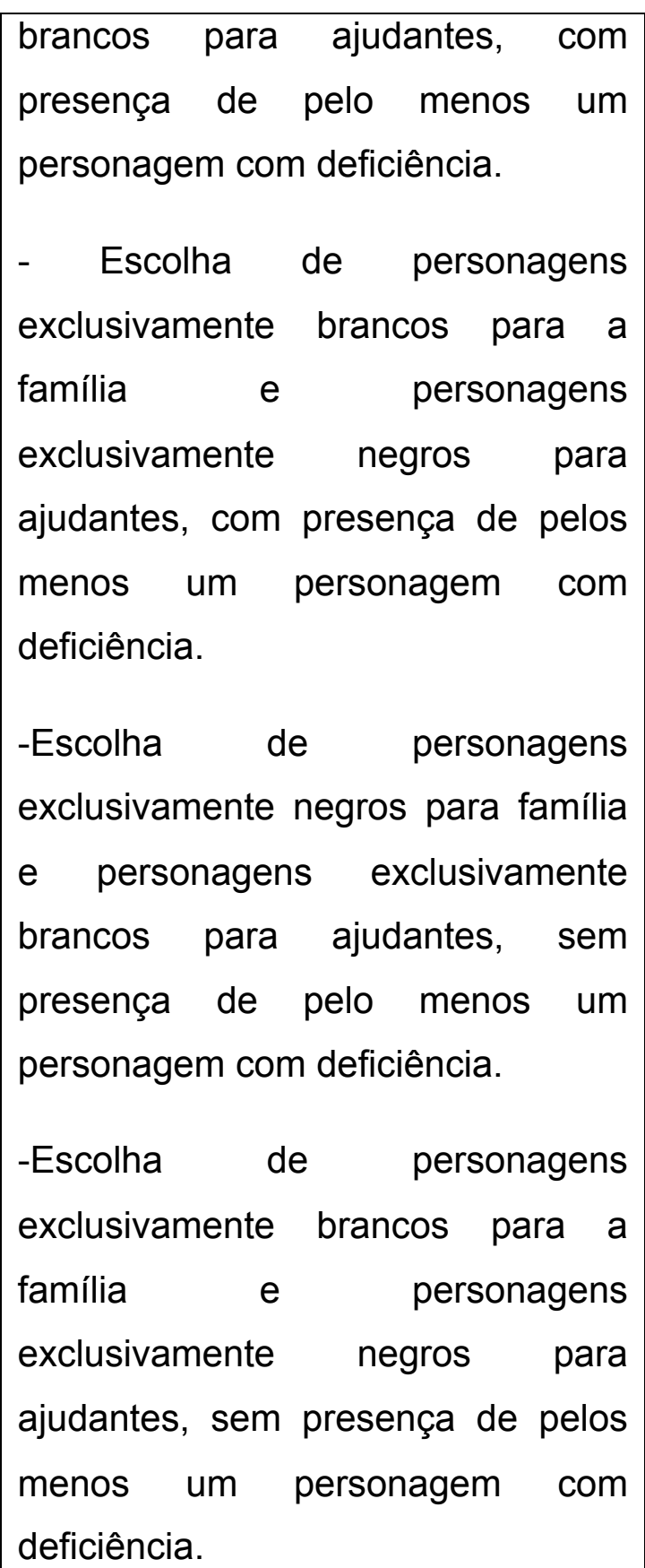 \\
\hline $\begin{array}{lr}\text { Situação } & 2 \\
\text { Escolha de um dos } \\
\text { personagens } \\
\text { criança } & \text { para } \\
\text { derrubar o aparelho } \\
\text { celular de um dos } \\
\text { personagens } & \text { que } \\
\text { representa } & \text { um }\end{array}$ & 3 & 0 & 2 & $\begin{array}{l}\text { - Criança branca } \\
\text { - Criança negra } \\
\text { - Criança branca com deficiência } \\
\text { - Criança negra com deficiência }\end{array}$ \\
\hline
\end{tabular}




\begin{tabular}{|c|c|c|c|c|}
\hline adulto cuidador. & & & & \\
\hline $\begin{array}{l}\text { Situação } 3- \\
\text { Seleção da punição } \\
\text { para o personagem } \\
\text { que representa a } \\
\text { criança que } \\
\text { derrubou } \\
\text { aparelho celular, } \\
\text { concordância e } \\
\text { obediência. }\end{array}$ & 0 & 5 & 5 & $\begin{array}{l}\text { - Não haverá punição. } \\
\text {-Conversar ou castigo, sem } \\
\text { concordar ou obedecer. } \\
\text { - Conversa ou castigo, concordando } \\
\text { e sem obedecer. } \\
\text { - Conversa ou castigo, concordando } \\
\text { e obedecendo. } \\
\text { - Bater, sem concordar. } \\
\text { - Bater, com concordância. }\end{array}$ \\
\hline $\begin{array}{l}\text { Situação } \\
\text { Seleção de um dos } \\
\text { personagens } \\
\text { realizar para } \\
\text { produção escolar } \\
\text { reconhecida pelos } \\
\text { adultos. }\end{array}$ & 0 & 0 & 0 & $\begin{array}{l}\text { - Criança negra com deficiência } \\
\text { - Criança branca com deficiência. } \\
\text { - Criança negra } \\
\text { - Criança branca. }\end{array}$ \\
\hline $\begin{array}{l}\text { Situação } 5 \\
\text { Determinação de } \\
\text { punição para um } \\
\text { personagem que } \\
\text { representa um filho } \\
\text { que desobedece } \\
\text { aos pais. }\end{array}$ & 3 & 3 & 5 & $\begin{array}{l}\text { - Não haverá punição. } \\
\text { - Conversar com a criança. } \\
\text { - Colocar a criança de castigo. } \\
\text { - Bater na criança } \\
\text { - Quebrar algo da criança } \\
\text {-Excluir o personagem da } \\
\text { brincadeira }\end{array}$ \\
\hline $\begin{array}{lrr}\text { Situação } & 6 & - \\
\text { Determinação } & \text { de }\end{array}$ & 0 & 1 & 0 & $\begin{array}{l}\text { - Não haverá punição. } \\
\text {-Conversar com a criança. }\end{array}$ \\
\hline
\end{tabular}




\begin{tabular}{|c|c|c|c|c|}
\hline $\begin{array}{l}\text { punição para o } \\
\text { personagem filho } \\
\text { da ajudante que a } \\
\text { desobedece. }\end{array}$ & 5 & 4 & 5 & $\begin{array}{l}\text { - Colocar a criança de castigo. } \\
\text { - Bater na criança } \\
\text { - Quebrar algo da criança } \\
\text {-Excluir o personagem da } \\
\text { brincadeira } \\
\text { OBS - Incluir mais } 1 \text { ponto caso a } \\
\text { punição escolhida seja mais } \\
\text { severa que a aplicada para } \\
\text { situação } 5 .\end{array}$ \\
\hline $\begin{array}{lr}\text { Situação } 7 & - \\
\text { Escolha de atitudes } \\
\text { que } \\
\text { personagens que } \\
\text { representam } \\
\text { crianças devem } \\
\text { tomar com relação } \\
\text { a outras crianças } \\
\text { quer tem } \\
\text { comportamentos } \\
\text { considerados } \\
\text { errados r pelos } \\
\text { adultos. }\end{array}$ & 3 & 5 & 5 & $\begin{array}{l}\text { - Não haverá punição. } \\
\text { - Conversar com a criança. } \\
\text { - Colocar a criança de lado na } \\
\text { brincadeira. } \\
\text { - Bater na criança } \\
\text { - Fazer um grupo para excluir a } \\
\text { criança. } \\
\text {-Excluir o personagem da } \\
\text { brincadeira }\end{array}$ \\
\hline $\begin{array}{lr}\text { Situação } & 8 \\
\text { Averiguar } & \text { os } \\
\text { papéis que cada } & \text { que } \\
\text { boneco } & \text { qua } \\
\text { representa } & \text { uma } \\
\text { criança assume na } \\
\text { representação de } \\
\text { uma brincadeira }\end{array}$ & 2 & 4 & 0 & $\begin{array}{l}\text { - Não há diferença entre papéis. } \\
\text {-Identificar como líder a criança do } \\
\text { mesmo sexo que o do sujeito de } \\
\text { pesquisa. } \\
\text { - Identificar como líder crianças com } \\
\text { deficiência. } \\
\text {-Identificar como líder crianças }\end{array}$ \\
\hline
\end{tabular}




\begin{tabular}{|c|c|c|c|c|}
\hline entre as crianças. & 4 & 5 & 4 & $\begin{array}{l}\text { negras. } \\
\text { - Identificar como líder crianças } \\
\text { brancas. } \\
\text { - Excluir algum personagem da } \\
\text { brincadeira. }\end{array}$ \\
\hline $\begin{array}{lr}\text { Situação } & - \\
\text { Inserção de um } & \text { um } \\
\text { personagem } & \text { com } \\
\text { deficiência } & \text { ou } \\
\text { negro em situação } \\
\text { de vantagem, caso } \\
\text { esse não tenha } \\
\text { sido previamente } \\
\text { escolhido dessa } \\
\text { forma pela criança } \\
\text { e análise da } \\
\text { atribuição do papel } \\
\text { que a criança dará. }\end{array}$ & 2 & 0 & 0 & $\begin{array}{l}\text { - Não há diferença entre os papéis. } \\
\text { - Cuidar do personagem. } \\
\text {-Colocar impossibilidades para o } \\
\text { personagem. } \\
\text {-Agredir física ou verbalmente o } \\
\text { personagem. } \\
\text { - Aceitar o personagem, mas não } \\
\text { incluí-lo na brincadeira após a } \\
\text { intervenção do pesquisador. } \\
\text {-Recusar a participação do } \\
\text { personagem. }\end{array}$ \\
\hline
\end{tabular}

Após somar os pontos atribuídos pela pesquisadora e pelos juízes para cada padrão de resposta, fez-se a média aritmética simples para chegar a uma posição que o padrão de resposta deveria ocupar na escala de atribuição de pontos que demonstra manifestação do preconceito. A partir desse cálculo distribuiu-se os padrões de resposta em ordem conforme a média aritmética, sendo que os casos em que houve empate ficaram a critério da pesquisadora decidir qual posição a resposta ocuparia na escala e após tal escalonamento de padrões de resposta atribui-se os valores de 0 a 5 na escala considerando-se 0 o padrão de resposta que apresenta menor tendência a manifestação de atitude preconceituosa e 5 o padrão de resposta que apresenta maior atitude preconceituosa, então chegou-se a valoração final conforme quadro abaixo. : 
Quadro VIII: escala final de pontuação para respostas a situações problema propostas na representação lúdica

\begin{tabular}{|c|c|}
\hline Situação problema & Padrão de resposta e pontuação \\
\hline $\begin{array}{lr}\text { Situação } & 1 \\
\text { escolha dos } & \text { papéis } \\
\text { para } & \text { os } \\
\text { personagens } & \end{array}$ & $\begin{array}{l}\text { ( } 0 \text { ) personagens de etnias diferentes na mesma família, } \\
\text { incluindo ou não a presença de pelo menos um } \\
\text { personagem com deficiência. } \\
\text { ( } 1 \text { ) escolha de todos os personagens da mesma etnia, } \\
\text { ou todos apresentando ou não deficiência. } \\
\text { ( } 2 \text { ) escolha de personagens exclusivamente negros } \\
\text { para família e personagens exclusivamente brancos para } \\
\text { ajudantes, com presença de pelo menos um } \\
\text { personagem com deficiência. } \\
\text { ( } 3 \text { ) escolha de personagens exclusivamente brancos } \\
\text { para a família e personagens exclusivamente negros } \\
\text { para ajudantes, com presença de pelos menos um } \\
\text { personagem com deficiência. } \\
\text { ( } 4 \text { ) escolha de personagens exclusivamente negros } \\
\text { para família e personagens exclusivamente brancos para } \\
\text { ajudantes, sem presença de pelo menos um } \\
\text { personagem com deficiência. } \\
\text { ( } 5 \text { ) escolha de personagens exclusivamente brancos } \\
\text { personagem a família e personagens exclusivamente negros } \\
\text { para deficiência. }\end{array}$ \\
\hline $\begin{array}{l}\text { Situação } 2 \text { - } \\
\text { Escolha de um dos } \\
\text { personagens } \\
\text { criança para } \\
\text { derrubar o aparelho } \\
\text { celular de um dos }\end{array}$ & $\begin{array}{l}\text { ( } 0 \text { ) - Criança branca. } \\
\text { ( } 1 \text { ) - Criança negra. } \\
\text { ( } 2 \text { ) Criança branca com deficiência. } \\
\text { ( } 3 \text { ) Criança negra com deficiência. }\end{array}$ \\
\hline
\end{tabular}




\begin{tabular}{|c|c|}
\hline $\begin{array}{ll}\text { personagens que } & \text { um } \\
\text { representa } & \text { um } \\
\text { adulto cuidador. } & \end{array}$ & \\
\hline $\begin{array}{l}\text { Situação } 3 \text { - } \\
\text { Seleção da punição } \\
\text { para o personagem } \\
\text { que representa a } \\
\text { criança que } \\
\text { derrubou o aparelho } \\
\text { celular, } \\
\text { concordância e } \\
\text { obediência. }\end{array}$ & $\begin{array}{l}\text { ( } 0 \text { ) Não haverá punição. } \\
\text { ( } 1 \text { ) Conversa ou castigo, sem concordar ou obedecer. } \\
\text { ( } 2 \text { ) conversa ou castigo, concordando e sem obedecer. } \\
\text { ( } 3 \text { ) conversa ou castigo, concordando e obedecendo a } \\
\text { punição. } \\
\text { ( } 4 \text { ) Bater, sem concordar. } \\
\text { ( } 5 \text { ) Bater, com concordância. }\end{array}$ \\
\hline $\begin{array}{lr}\text { Situação } & 4- \\
\text { Seleção de } & \text { um dos } \\
\text { personagens } & \text { para } \\
\text { realizar } & \text { uma } \\
\text { produção } & \text { escolar } \\
\text { reconhecida } & \text { pelos } \\
\text { adultos. } & \end{array}$ & $\begin{array}{l}\text { ( } 0 \text { ) Criança negra com deficiência. } \\
\text { ( } 1 \text { ) Criança negra. } \\
\text { ( } 2 \text { ) Criança branca com deficiência. } \\
\text { ( } 3 \text { ) Criança branca. }\end{array}$ \\
\hline $\begin{array}{lr}\text { Situação } 5 & - \\
\text { Determinação } & \text { de } \\
\text { punição para um } & \text { que } \\
\text { personagem } & \text { representa um filho } \\
\text { que desobedece } \\
\text { aos pais. }\end{array}$ & $\begin{array}{l}\text { ( } 0 \text { ) Não haverá punição. } \\
\text { ( } 1 \text { ) Conversar com a criança. } \\
\text { ( } 2 \text { ) Colocar a criança de castigo. } \\
\text { ( } 3 \text { ) Bater na criança. } \\
\text { ( } 4 \text { ) Quebrar algo da criança. } \\
\text { ( } 5 \text { ) Excluir o personagem da brincadeira. }\end{array}$ \\
\hline $\begin{array}{lr}\text { Situação } \quad 6 & - \\
\text { Determinação } & \text { de } \\
\text { punição para } & \text { o } \\
\text { personagem filho da }\end{array}$ & $\begin{array}{l}\text { ( } 0 \text { ) Não haverá punição. } \\
\text { ( } 1 \text { ) Conversar com a criança. } \\
\text { ( } 2 \text { ) Colocar a criança de castigo. }\end{array}$ \\
\hline
\end{tabular}




\begin{tabular}{|c|c|}
\hline $\begin{array}{l}\text { ajudante que a } \\
\text { desobedece. }\end{array}$ & $\begin{array}{l}\text { ( } 3 \text { ) Bater na criança. } \\
\text { ( } 4 \text { ) Quebrar algo da criança. } \\
\text { ( } 5 \text { ) Excluir o personagem da brincadeira. } \\
\text { OBS - Incluir mais } 1 \text { ponto caso a punição escolhida } \\
\text { seja mais severa que a aplicada para situação } 5 \text {. }\end{array}$ \\
\hline $\begin{array}{l}\text { Situação } 7 \\
\text { Escolha de atitudes } \\
\text { que os personagens } \\
\text { que representam } \\
\text { crianças devem } \\
\text { tomar com relação a } \\
\text { outras crianças que } \\
\text { tem } \\
\text { comportamentos } \\
\text { considerados } \\
\text { errados } \\
\text { adultos. }\end{array}$ & $\begin{array}{l}\text { ( } 0 \text { ) Não haverá punição. } \\
\text { ( } 1 \text { ) Conversar com a criança. } \\
\text { ( } 2 \text { ) Colocar a criança de lado na brincadeira. } \\
\text { ( } 3 \text { ) Bater na criança. } \\
\text { ( } 4 \text { ) Fazer um grupo para excluir a criança. } \\
\text { ( } 5 \text { ) Excluir o personagem da brincadeira. }\end{array}$ \\
\hline $\begin{array}{l}\text { Situação } 8 \\
\text { Averiguar os papéis } \\
\text { que cada boneco } \\
\text { que representa uma } \\
\text { criança assume na } \\
\text { representação de } \\
\text { uma brincadeira } \\
\text { entre as crianças. }\end{array}$ & $\begin{array}{l}\text { ( } 0 \text { ) Não há diferença entre papéis. } \\
\text { ( } 1 \text { ) Identificar como líder crianças com deficiência. } \\
\text { ( } 2 \text { ) Identificar como líder a criança do mesmo sexo que } \\
\text { o do sujeito de pesquisa. } \\
\text { ( } 3 \text { ) Identificar como líder crianças negras. } \\
\text { ( } 4 \text { ) Identificar como líder crianças brancas. } \\
\text { ( } 5 \text { ) Excluir algum personagem da brincadeira }\end{array}$ \\
\hline $\begin{array}{lrr}\text { Situação } & 9 & - \\
\text { Inserção de } & \text { um } \\
\text { personagem } & \text { com } \\
\text { deficiência } & \text { ou negro }\end{array}$ & $\begin{array}{l}\text { ( } 0 \text { ) Aceita e não há diferença entre os papéis. } \\
\text { ( } 1 \text { ) Cuidar do personagem. } \\
\text { ( } 2 \text { ) Colocar impossibilidades para o personagem. }\end{array}$ \\
\hline
\end{tabular}




\begin{tabular}{|c|c|}
\hline $\begin{array}{l}\text { em situação de } \\
\text { vantagem, caso } \\
\text { esse não tenha sido } \\
\text { previamente } \\
\text { escolhido dessa } \\
\text { forma pela criança e } \\
\text { análise da atribuição } \\
\text { do papel que a } \\
\text { criança dará. }\end{array}$ & $\begin{array}{l}\text { ( } 3 \text { ) Agredir física ou verbalmente o personagem. } \\
\text { ( } 4 \text { ) Aceitar o personagem, mas não incluí-lo na } \\
\text { brincadeira após a intervenção do pesquisador. } \\
\text { ( } 5 \text { ) Recusar a participação do personagem. }\end{array}$ \\
\hline
\end{tabular}

\section{Apresentação e discussão dos resultados}

\subsection{Apresentação e discussão dos resultados obtidos da observação lúdica}

As observações lúdicas transcorreram por um tempo aproximado de 10 minutos, variável de acordo com o tempo de interesse das crianças pelos brinquedos apresentados. Os grupos se formaram espontaneamente pelas crianças, de forma que a professora da sala de aula e a pesquisadora pediram para que as crianças se dividissem para brincar com os brinquedos que a pesquisadora havia levado ou para brincar com os brinquedos pertencentes à sala de aula. A pesquisadora apresentou às crianças uma casinha de bonecas aberta, com todos os bonecos construídos para a pesquisa dentro, dispostos de forma aleatória. Devido à novidade, as crianças tenderam a buscar primeiramente os materiais ofertados pela pesquisadora, mas com breve intervenção da professora, logo se subdividiram em grupos de aproximadamente o mesmo número de crianças. A brincadeira transcorreu sem a intervenção da pesquisadora, das professoras ou da auxiliar específica para a criança diagnosticada como do espectro do autismo. Enquanto as crianças brincavam a pesquisadora fez alguns apontamentos de descrição desse momento lúdico que está registrada integralmente no apêndice IV desta pesquisa, ressaltando que houve mais ações com os bonecos no momento do brincar do que a fala propriamente dita. A brincadeira consistiu basicamente em jogo simbólico, no qual a criança tem a oportunidade de representar o seu cotidiano a partir do momento lúdico. 
Em todas as salas de aula observou-se que as crianças manifestaram interesse pelos brinquedos apresentados, e conseguiram identificar as diferenças de cor de pele e presença ou ausência de deficiência propostos. As diferenças relacionadas à presença ou ausência de deficiência foram mencionadas por algumas crianças criando hipóteses explicativas sobre a necessidade do uso da muleta ou a ausência de pernas, a diferença relacionada à cor da pele não foi mencionada pelas crianças. Concordando com Fazzi (2009) quando expõe a necessidade de interpretar pesquisas com crianças a partir de sua lógica de pensamento próprio, observou-se que as falas espontâneas das crianças ao se deparar com bonecos representando diferentes características mostram que existe uma percepção sobre as diferenças, mas não houve um juízo de valor atribuído a essas diferenças, seja pela forma aleatória como escolheram os brinquedos com os quais iriam brincar ou por falas específicas em que identificavam bonecos com diferentes características atuando com as mesmas possibilidades como por exemplo na situação em destaque "Um dos meninos pergunta o que eram os y (muletas) que estavam nos braços da boneca, outro menino responde que são cavalinhos e começam a brincar de fazer os bonecos andar a cavalo. Uma menina diz que o cavalo ajuda aos bonecos que não tem pernas andar, todos continuam brincando de cavalgar indiscriminadamente com os bonecos". Outra situação que pode ser destacada como exemplo é: "Um dos meninos pega todas as muletas que denomina como y e diz que vai sortear entre as bonecas, que eles designaram como filhos, para poderem brincar. Uma das meninas responde que podem brincar, mas que é preciso ajudar aos bonecos que não tem pernas, porque se tirar os " $y$ " deles irão cair." As falas e atitudes típicas das crianças nas duas situações representadas mostram que elas percebem diferenças e estão se organizando cognitivamente para compreender o que estas significam e quais implicações podem apresentar na vida das pessoas, o que reforça a importância de se atentar para a mediação do adulto nestas relações, favorecendo a possibilidade do conhecimento e da identificação com as diferenças.

As situações acima expostas também podem ilustrar a forma como as crianças constituem identificação com aquele que lhe é diferente. Nestas relações percebe-se que embora uma criança possa desconhecer a função da muleta como ajuda técnica para a pessoa com deficiência física, outra criança do mesmo grupo 
auxilia na explicação e no reconhecimento da presença da deficiência e embora todos compreendendo que a muleta tinha função específica, optam por continuar a brincadeira não diferenciando os bonecos que representavam ausência ou presença da deficiência, valorizando a identificação entre os diferentes e a possibilidade do brincar como prioridade, sem hierarquização de papéis.

Também observou-se, como o esperado para crianças na faixa etária pesquisada, um brincar que ainda tende à individualidade e ao acúmulo de brinquedos de forma individual. Mas ainda assim as crianças já mostraram percepção do outro quando imitaram os movimentos da brincadeira uns dos outros ou quando intervém no brincar do amigo, o que se faz especialmente importante para esta pesquisa pois mostra que as crianças estão na fase de aprender com o comportamento do outro, tendendo a reproduzir os valores que lhes são passados.

Outro fator de importante destaque nesta etapa da pesquisa foi a presença da empatia e a capacidade de cuidar e amar ao outro que pode ser notada com a reprodução dos cuidados aos brinquedos como colocá-los para tomar banho ou para dormir e nas intervenções realizadas dentro do grupo nas quais crianças apontavam que outras que estavam batendo ou jogando os brinquedos poderiam machucá-los. Segundo Adorno (2006) um dos fatores importantes para que as crianças sejam educadas de forma a evitar a reprodução da barbárie é a presença do amor, percebeu-se nas brincadeiras livres entre as crianças que apesar da agitação no brincar típico e esperado para essa faixa de idade, houve a preocupação com o outro ser humano representado pelo cuidado com o brinquedo ou mesmo na forma como as crianças se relacionavam entre si. Um fator de destaque que pode ilustrar essa observação é que as crianças ao finalizar a brincadeira, mesmo sem a intervenção do adulto, guardavam os brinquedos com cuidado de forma que mesmo as crianças que já haviam dispersado da brincadeira voltavam para ajudar a guardar os brinquedos quando percebiam algumas crianças fazendo.

Ainda no tocante à relação das crianças com e sem deficiência pode-se observar que não houve manifestação de intolerância ou de diferenciação dos brinquedos nesse momento de brincar livre. Também não houve diferenciação significativa entre os grupos que já possuíam contato com crianças com deficiência ou pessoas negras e os que não possuíam. Vale apenas destacar na relação entre 
as crianças com e sem deficiência que a criança que possui transtorno do espectro do autismo tende a apresentar um brincar mais isolado das demais, e este comportamento pareceu não ser muito notado pelo grupo, como na passagem: "Criança com diagnóstico de transtorno do espectro do autismo estava segurando uma boneca negra nas mãos, a batia na mesa; nesse momento começa a pegar todas as bonecas e puxar para elas. Outras crianças do grupo não falam nada, mas tiram bonecos da mão dela, criança com espectro do autismo grita e uma das meninas diz que nem todos os brinquedos serão para ele, tomando o brinquedo da mão da criança. Criança do espectro do autismo volta a bater boneca negra na mesa e demais crianças continuam atividade de dar banho nas bonecas". O comportamento que é característico do transtorno do espectro do autismo não inibe ou modifica a relação entre as crianças que não possuem deficiência, o que é importante na observação do outro como uma possibilidade de vir a ser.

Ao finalizar a etapa de observação lúdica pode-se constatar que as crianças não manifestaram diferenciações de atitude no momento de brincar com os bonecos que representavam diferenças, o que pode caracterizar uma não identificação com as atitudes do preconceito quando não estão sendo mediadas pelo adulto e não reproduzem o preconceito tendendo a rechaçar brinquedos que representam características diferentes. Também pode-se observar que as crianças identificaram as diferenças representadas pelos bonecos, o que se faz necessário para a aplicação da próxima etapa da pesquisa, que foi a representação lúdica.

\subsection{Apresentação e Discussão dos dados obtidos na representação lúdica}

Conforme descrito na apresentação dos instrumentos de pesquisa, a representação lúdica ocorreu na interação entre pesquisadora e criança, sendo que as crianças já haviam tido um contato prévio com os bonecos durante a observação lúdica, porém sem a mediação do adulto. Foram expostas as situações problemas planejadas e as respostas obtidas na etapa da representação lúdica estão dispostas em quadros constantes no apêndice $\mathrm{V}$.

Avaliando os dados encontrados com relação ao paralelo proposto com os índices que foram mensurados pela escala $F$ no trabalho de Adorno et all (1965) temos que os itens um, dois, quatro, oito e nove observados na representação lúdica 
mediram os índices de propensão ao convencionalismo. Pode-se observar a partir dos dados apresentados que as crianças pesquisadas ainda não internalizaram os valores impostos pela cultura dominante, ou seja, valores que impingem o preconceito e a discriminação ante as diferenças; especialmente representado pelo fato de que a maior parte das crianças não escolheu famílias que representam todas características semelhantes e que não excluíram elementos que não são fenotipicamente semelhantes ao que deve compor seu núcleo familiar real para compor as famílias representadas no brincar. Por vezes as crianças declaram escolher os personagens para ser mães ou pais aqueles que tem "o cabelo mais legal" ou "o cavalinho mais legal", mostrando que as características sinalizadoras da diferença como a cor de pele ou a presença de deficiência não foram atributos definidores para a escolha dos bonecos que representariam as famílias na brincadeira. Outro ponto de especial interesse foi o fato de que a situação problema de numero nove não precisou ser aplicada, tendo em vista que todas as crianças analisadas já haviam utilizado os bonecos que representavam pessoas com deficiência em suas brincadeiras. A atribuição de papeis que representam características positivas e características negativas também não obteve altas pontuações, demonstrando que as crianças ainda não atribuem características positivas aos bonecos que representam a classe dominante. Vale destacar que o ambiente escolar em que as crianças estão imersas valoriza uma cultura de respeito e contato com as diferenças, possibilitando que as crianças possam se identificar umas com as outras, o que está representado na brincadeira. Destaca-se ainda na primeira situação problema na qual as respostas para a formação das famílias, embora em sua grande maioria não tenham sido compostas por pessoas de mesma etnia ou com presença e ausência de deficiência, mas ainda tenderam a representar a estrutura familiar convencional focalizada em pai, mãe e filhos; o que leva a pensar que as crianças já percebem e reproduzem de alguma forma a estrutura social dominante vigente, porém em seu contexto existe a possibilidade de contato e de discussão de alguns padrões que incluem as diferenças, de forma que as famílias apesar de possuir uma estruturação convencional, não representam o que fenotipicamente parece ser a realidade das crianças pesquisadas. Pode-se afirmar então que as crianças já possuem condições para identificar um padrão social, mas ainda não aderem e reproduzem totalmente esse padrão, o que culminou em baixos 
escores para o índice de convencionalismo observado em todas as salas de aula pesquisadas.

A medida de submissão à autoridade, testada pela situação problema número três foi uma das que pontou maiores escores, porém também não são escores que ultrapassam o valor de escore médio possível para a situação, denotando que embora alto quando comparado às demais respostas encontradas na situação de testagem, ainda não é identificado como um índice de submissão à autoridade elevado. Essa medida pode ser compreendida quando comparamos com as medidas de agressividade autoritária e de crença de que o mundo pode submeter a castigos, que foram ambas testadas pelas situações problema três, cinco, seis e sete; pois estas foram as situações problema em que as crianças pontuaram os mais altos escores, porém sem ultrapassar do ponto médio, indicando um baixo índice de agressividade autoritária e de crença em que o mundo pode submeter a castigos. Os três itens avaliados eram realmente os em que se esperava que as crianças obteriam maior pontuação, pois dada sua faixa etária e sua possibilidade de autonomia relativa, ainda encontram as leis exteriorizadas e identificam no adulto o limite para a imposição de regras quanto ao certo e errado. Porém nota-se que o autoritarismo, identificado como uma das potenciais características dos indivíduos preconceituosos, ainda não se encontra instalado nas crianças, pois embora um elevado número de respostas sugira o bater como um castigo a ser aplicado frente ao descumprimento de normas, percebe-se que as outras opções como o conversar também obtiveram bastante pontuação, de forma que a criança por sua tenra idade ainda está elaborando o potencial cognitivo para discussão de regras e tende a utilizar mais o físico para a compreensão destas, mas nota-se que no geral as crianças representam nas brincadeiras uma tentativa de evitar as regras e por fim o bater como forma de imputar um padrão de comportamento aceitável por todos. Importante avaliar essas características juntamente com a possibilidade de identificação com as figuras de poder, medida pelas situações problema cinco e seis, nas quais as crianças pontuaram menos que nas situações problemas identificadas anteriormente, mostrando que embora elas reconheçam um certo nível de autoritarismo como necessário para o cumprimento das normas, ainda não internalizam ou reproduzem tal autoritarismo, relegando- o aos adultos; o que mostra na diferença de respostas para as situações problema em que os adultos deveriam imputar uma punição para a criança desobediente e quando as próprias crianças 
deveriam imputar uma punição ao amigo desobediente, de forma que na última situação as crianças não mostravam-se como responsáveis pela julgamento de alguém do seu grupo de pares, geralmente deixando-o sem uma punição ou apenas conversando com a criança. Isso se faz especialmente importante ao pensarmos no desenvolvimento do preconceito pois permite que levantemos a hipótese de que essas crianças ainda não se encontram demasiadamente oprimidas por uma autoridade imposta arbitrariamente e portanto não sentem a necessidade de oprimir ao próximo como forma de descarga afetiva. Também se faz importante notar a possibilidade de identificação entre as crianças, que geralmente não punem as outras entendendo que podem estar no lugar de quem também descumpre as regras, não precisando assim encontrar um grupo específico para culpar pelo que consideram errado e assim purgar sua culpa. Ainda vale destacar que não houve diferença entre as punições selecionadas para os filhos das famílias nucleares e para os filhos das empregadas que trabalhavam com as famílias durante a representação lúdica, reforçando novamente a identificação das crianças entre si e a aceitação das diferenças representadas ludicamente na pesquisa, sejam essas no tocante à presença ou ausência de deficiência, quanto a cor de pele ou quanto à posição sócio econômica representada.

A hipótese número dois não pode ser testada, pois não houve diferenciação no momento do brincar que revelasse manifestação de preconceito ligada a características diferentes representadas no boneco, o que fez inclusive com que a situação problema número nove não fosse aplicada no momento da representação lúdica.

Após estabelecer as relações entre as situações problema aplicadas aos sujeitos de pesquisa e a presença dos índices de convencionalismo, submissão à agressividade, agressividade autoritária, identificação com figuras de poder e crença de que o mundo pode submeter a castigos, fez se importante avaliar se a proposta da representação lúdica pode ser considerada um instrumento confiável para fornecer tais dados, para tanto utilizou-se a prova de estatística Alpha de Cronbach que mede a confiabilidade do teste como instrumento de pesquisa. Os dados obtidos como respostas totais para as situações problema e dispostos no apêndice $V$, excetuando-se as respostas fornecidas pela criança oito da turma $A$ que não respondeu às situações problema, foram inseridos no programa disponibilizado Free statistcs software disponível no site www.wessanet. O resultado obtido foi um valor 
para Alpha de Cronbach de 0,7601 e o resultado padrão para um Alpha de Cronbach que indique um grau de confiabilidade no teste é de 0,8581. Dado que se trata da primeira aplicação do teste e de um grupo com amostras pequenas, pode-se dizer que o teste apresentou um bom índice de confiabilidade, embora possa ser replicado em amostras maiores e com públicos imersos em diferentes condições ambientais para ampliar a possibilidade de confiabilidade no teste.

Sendo assim, pode-se considerar que a hipótese número um desta pesquisa não foi confirmada, de forma que os índices de: convencionalismo, submissão à agressividade autoritária, agressividade, identificação com figuras de poder e crença de que o mundo pode submeter a castigos; foram medidos com um bom grau de confiabilidade pelo teste da representação lúdica que demonstrou índices que não se encontram em valor elevado ou mais alto do que o ponto médio da escala likert de padrão de respostas, ou seja, indicam que embora já reconheçam estruturas sociais que levem ao padrão da formação do preconceito, as crianças pesquisadas ainda não representam esse padrão em seu momento de brincar.

Ainda analisando os resultados mostrados nos quadros de respostas à representação lúdica dispostos no apêndice $V$, porém agora com foco na pontuação geral das crianças, observa-se que todas as crianças que participaram da pesquisa obtiveram pontuação geral abaixo do ponto médio pois o máximo de pontos que uma criança poderia obter na representação lúdica seria 41 se somarmos as pontuações máximas atribuídas a cada item, e nos resultados obtivemos a criança que teve maior pontuação com um valor de 19 e a que obteve menor pontuação obteve dois pontos, assim pode-se dizer que todas as crianças que participaram da pesquisa tem menor tendência ao desenvolvimento do preconceito. Também observa-se que os alunos da turma $B$ foram os que obtiveram escores totais mais altos e as crianças da turma $A$ foram as que obtiveram escores totais menores. Para verificar se houve diferença significativa entre as respostas fornecidas pelas crianças que possuem contato em sala de aula com as crianças com deficiência e as crianças que não possuem contato, utilizou-se a prova estatística de Kruskall- Wallys com o intuito de comparar as quatro turmas de forma independente. A prova $U$ de MannWhitney foi utilizada para comparar os grupos $A D$ e $B C$ formados a partir do agrupamento das salas de aula que atendem crianças com deficiência e daquelas que não atendem, bem como para comparar a turma $A$ com a turma $D$ e a turma $B$ com a turma $\mathrm{C}$, no intuito de encontrar diferenças significativas nas hipóteses 
independentes. As provas estatísticas foram calculadas conforme as instruções contidas na obra de Siegel (1979) e utilizado o programa que realiza cálculos estatísticos SPSS. Para calcular as provas estatísticas foram considerados os dados apresentados no apêndice $\mathrm{V}$ e um número de sujeitos de pesquisa de 36 crianças, sendo que o grupo $A D$ contou com 18 crianças e o grupo $B C$ também com 18 crianças. Houve necessidade de desconsiderar as respostas de uma das crianças, a criança oito do grupo $A$, nos testes estatísticos porque ela não respondeu a maioria das situações problemas propostas na representação lúdica. Os resultados obtidos na prova de Kruskall- Wallys, U de Mann- Withney e o cálculo das medianas para a pontuação total obtida por criança segue na tabela abaixo:

Tabela I: resultados medianas, Kruskall-Wallys e U de Mann-Withney calculados para a pontuação total obtida por criança

\begin{tabular}{|l|c|c|c|}
\hline & Medianas & Kruskall- Wallys & $\begin{array}{c}\text { U de Mann- } \\
\text { Withney }\end{array}$ \\
\hline Turma A & 5 & \multirow{2}{*}{$\mathrm{X}^{2}(3)=8,223$} & $\mathrm{Z}=1,788$ \\
\cline { 1 - 2 } Turma D & 9 & & $\mathrm{Z}=2,01$ \\
\cline { 1 - 2 } Turma B & 13 & & $\mathrm{Z}=1,112$ \\
\cline { 1 - 2 } Turma C & 7 & & \\
\hline Grupo AD & 8 & & \\
\hline
\end{tabular}

Considerando um valor de $p=0,0042$ o valor de $X^{2}$ conforme tábua $C$ (Siegel, 1979) é 7,82 , sendo assim, segundo a prova de Kruskall-Wallys se avaliarmos as respostas fornecidas pelas turmas $A, B, C$ e $D$ teremos que apresentam diferenças significativas entre si, ou seja, observa-se que há diferenças significativas entre as formas que as crianças responderam as situações problema conforme o agrupamento de sala de aula em que se encontram. Fez-se então necessário compreender, comparando os agrupamentos independentes, em que conformação houve a diferença significativa. Para tanto utilizou-se a prova $U$ de Mann-Withney para comparar as amostras independentes formadas pelos grupos $A D$ e $B C$, com o qual obtemos um valor equivalente a um $p=0,279$, indicando que não há diferença significativa entre os grupos comparados, ao nível de significância estabelecido para esta pesquisa $(p<0,05)$. Ao aplicar a prova comparando a turma $A$ com a turma $D$ também não foi encontrada diferença significativa $(p=0,074)$. Ao comparar a turma 
B e a turma $C$ encontrou-se a existência de diferença significativa entre os grupos $B$ e $C(p=0,043)$. Assim, pode-se dizer que a diferença significativa encontrada entre as turmas $A, B, C$ e $D$ está quando comparamos as amostras independentes formadas pelos grupos $\mathrm{B}$ e $\mathrm{C}$.

Ao avaliar as medianas encontradas para o valor total das respostas das crianças e compará-las entre si, observa-se que a turma A é a que apresenta menor índice de respostas com tendência ao preconceito, e a turma $\mathrm{C}$ é a segunda turma que apresenta respostas com menor índice de tendência ao preconceito. A turma que fornece respostas cuja mediana indica maior índice de tendência ao preconceito é a turma $B$, embora seja importante salientar que todas as turmas obtiveram resultados que demonstram baixo índice de tendência ao preconceito. Assim, apesar de as turmas apresentarem índices diferentes de respostas com maior ou menor tendência à manifestação do preconceito, não é possível atribuir à presença ou ausência do contato com crianças com deficiência em sala de aula.

Os dados analisados acima negam a hipótese número três desta pesquisa indicando que para a amostra estudada não houve diferenças significativas entre as respostas fornecidas pelos grupos que possuem contato com crianças com deficiência em suas salas de aula e os que não possuem. Porém ainda assim observou-se que houve diferença significativa entre as amostras independentes quando considerado todas as turmas avaliadas, diferença encontrada na comparação da turma B com a turma C. Para explicar tal diferença seria necessário conhecer de forma mais aprofundada o perfil das amostras investigando o histórico de relação com o preconceito que as crianças possuem fora do ambiente escolar, porém voltando o foco para o ambiente escolar em que a pesquisa foi realizada, observa-se que a mediação do adulto nas relações entre as crianças e a forma de apresentação dos grupos representantes das minorias para crianças que não possuem contato direto com as mesmas também influência na forma como as crianças manifestam respostas com maior ou menor tendência ao preconceito. Apesar de não ter sido possível testar a hipótese número dois desta pesquisa pois as crianças não apresentaram, no momento da representação lúdica, respostas que manifestaram tendência ao preconceito e que permitissem a intervenção; o fato de uma das turmas pesquisadas apresentar respostas que denotam maior tendência ao preconceito quando comparada às demais turmas, mesmo que tais respostas não indiquem elevados índices de manifestação do preconceito, aponta para que a 
mediação do adulto representa um papel importante na relação da criança com o desenvolvimento do preconceito, dando indícios de que a hipótese número dois desta pesquisa deve ser reavaliada utilizando para tanto um instrumento mais específico.

Importante ainda destacar que conforme os dados fornecidos pela coordenação pedagógica da escola, já há uma preocupação como diretriz escolar em oferecer às crianças contato mediado de maneira positiva com as diferenças seja de cor de pele ou de presença e ausência de deficiência, o que deve ser levado em consideração ao analisar o baixo índice de respostas que indicam manifestação de preconceitos pelas crianças; porém ainda assim a presença e o contato com crianças com deficiência em sala de aula mediados adequadamente pelo adulto contribuem para minimizar ainda mais as características que denotam manifestação do preconceito, atuando de maneira favorável à inclusão de pessoas com deficiência em salas de aula regular como uma das maneiras para auxiliar à minimização da formação do preconceito em crianças. 


\section{Considerações Finais}

A questão que norteou as investigações empíricas desta pesquisa remete à identificação de repostas que podem representar manifestações preconceituosas em crianças com idade entre três e quatro anos, o que se faz especialmente importante ao pensar na proposição de Adorno (2006) na qual se deve intervir na criança de tenra idade para minimizar efeitos do preconceito no adulto. Os dados obtidos na observação lúdica, indicam que embora as crianças tenham notado a representação da diferença nos bonecos e formulem hipóteses para explicá-las, não manifestam ainda atitudes que remetem a exclusão ou mesmo ao preconceito com aqueles que simbolizam a diferença; porém certamente este dado deve ser referendado por outras pesquisas, uma vez que não foi obtido por meio da observação de mais de um pesquisador. Já na etapa de pesquisa da representação lúdica pode-se constatar a partir do tratamento estatístico dos dados um padrão de confiabilidade nas respostas obtidas durante a pesquisa e estas apontam para um baixo escore para manifestação de preconceito, em todas as crianças que participaram. As respostas que denotam baixa tendência de manifestação do preconceito em todas as crianças que participaram da pesquisa se faz um dado importante pois pode indicar que apesar de já reconhecer as diferenças, as crianças ainda não tendem a internalizá-las e reproduzi-las, concordando com Adorno (2006) que essa seria a fase ideal para uma intervenção com vistas à minimização dos efeitos do preconceito na formação do indivíduo.

Importante também direcionar o foco da análise dos dados encontrados para as respostas obtidas a partir dos diferentes agrupamentos em que as crianças se encontraram subdivididas, pois apesar de todos pontuarem baixos escores para manifestação do preconceito houve diferenças significativas entre as pontuações alcançadas em cada grupo estudado, porém tais diferenças não foram encontradas, como era esperado entre os grupos formados por aquelas crianças que estudam com outras que possuem deficiência e as que não estudam, mas sim entre grupos formados por crianças que não estudam com crianças com deficiência. Tal dado não desqualifica a importância da inclusão escolar como uma forma de minimizar a tendência ao desenvolvimento do preconceito, pois apesar de não possuir contato direto em sala de aula com a criança com deficiência, as crianças pesquisadas possuem contato constante com crianças com deficiência que estudam na escola e por se tratar de grupos da mesma faixa etária, realizam atividades em conjunto com 
frequência. Outro fator que se destaca é que a escola apresenta uma proposta inclusiva, o que não remete necessariamente a presença de alguma criança com deficiência em sala de aula, mas sim ao apresentar materiais e temas que abordem a questão das diferenças no cotidiano escolar, e apesar de não possuirmos dados suficientes para afirmar que o padrão de respostas que denota baixo índice de manifestação do preconceito deve ser atribuído à inclusão escolar, afirma-se que a pesquisa realizada em uma escola que possui diretrizes favoráveis à inclusão apresentou um padrão de respostas baixo quando as crianças foram avaliadas com relação à manifestação de atitudes que tendiam ao preconceito, sendo assim, observa-se a necessidade de ampliar pesquisas que investiguem a relação entre inclusão escolar e a tendência à manifestação do preconceito em crianças pequenas.

Mas ainda faz-se necessário avaliar porque mesmo com essa pontuação que denota baixo padrão de respostas com tendência a manifestação do preconceito, observou-se que uma das salas apresentou escore de respostas significativamente mais alto que as demais, o que leva à necessidade de ampliar as investigações para compreender se o padrão de respostas fornecido pelas crianças dessa sala de aula deve ser atribuído às diferenças encontradas no ambiente em que a criança vive fora da escola ou se pode ser atribuído à mediação do adulto em sala de aula. Importante destacar que como todas as outras turmas apresentaram ainda mais baixos índices de tendência a manifestação do preconceito e não houve diferença significativa entre elas, e que todas as crianças vêm de ambientes e formas de criação familiar também diferentes, há uma tendência para que a explicação do padrão de diferença significativa nas respostas da turma denominada como B seja atribuído à mediação do adulto em sala de aula. Vale lembrar que apesar de os professores receberem diretrizes inclusivas passadas pela coordenação pedagógica, a forma de mediar o cotidiano em sala de aula e o trabalho com elementos que contribuem para a formação do preconceito é realizado por professores de forma individual em suas salas de aula. Isso reforça a necessidade de um acompanhamento e da formação constante dos professores no tocante à importância de como lidar com as diferenças e a formação do preconceito, para que ele possa realizar a mediação na relação entre crianças e os grupos que simbolizam as minorias com vistas a proporcionar o pensamento reflexivo e a tendência a desconstruir estereótipos. Ao lembrar que o adulto, no caso o professor, responsável 
por essa mediação é produto de uma sociedade imersa no preconceito, reforça-se ainda mais a necessidade de acompanhamento constante, favorecendo que o professor repense seus valores em pequenas atitudes no cotidiano com as crianças, afim de identificar padrões pré-estabelecidos que levam ao desenvolvimento do preconceito e possam minimiza-los.

Comparando os dados desta pesquisa com dados encontrados por outros pesquisadores e apresentados na introdução teórica desta pesquisa, utilizando sujeitos com idades semelhantes, os achados desta pesquisa concordam com os dados observados por Cruz (2015), o que reforça a importância de trabalhar com crianças da referida faixa etária com vistas a minimizar a formação do preconceito. Também ao retomar as pesquisas de França e Monteiro (2004), percebe-se que o esperado seria que crianças de três a quatro anos manifestassem explicitamente falas excludentes ou que representassem a estigmatização da diferença, pois em seus estudos apontam que crianças mais novas exprimem mais atitudes que denotam o preconceito, o que tende a diminuir com a internalização das normas sociais sobre o que se deve falar ou não em público, que ocorre de acordo com a idade. Vale destacar que as autoras não compreendem que os sentimentos ligados ao preconceito diminuam com a idade, mas apenas diminui sua possibilidade de expressão. Sendo assim, conclui-se que as crianças pesquisadas por Cruz (2015) e as que participaram desta pesquisa já percebem as diferenças, porém ainda não atribuem significações preconceituosas ao diferente, buscando mais compreender como se dão as diferenças singulares entre os humanos, do que a atribuir valores para elas. Aqui novamente reforça-se a importância da intervenção precoce em crianças com vistas a minimizar a formação do preconceito, apontando para a idade entre os três e quatro anos como um momento ideal para isso. Porém a pesquisa de Porter (1973) com crianças entre três e cinco anos de idade encontra que apesar de ainda não compreender e nomear o racismo, as crianças já apresentavam um colorido afetivo negativo para os brinquedos que simbolizavam a cor negra. Vale destacar que a contradição pode ser compreendida porque a pesquisa de Porter (1973) foi realizada com décadas de diferença e nos Estados Unidos, ao que se atribui a diferença dos achados para um padrão cultural de respostas representantes da época em que a pesquisa foi realizada ou mesmo representante da cultura do país onde a pesquisa foi realizada. Novamente aqui se faz a importância de ampliar as investigações acerca dos fatores que levam ao desenvolvimento do preconceito 
em crianças pequenas, com vistas a identificar o papel cultural e mesmo os possíveis avanços obtidos a partir das campanhas anti preconceito.

Ainda vale destacar que embora os dados encontrados nesta pesquisa indiquem o baixo índice de manifestação do preconceito em crianças com idades entre três e quatro anos, esses dados foram colhidos com uma população de crianças estudantes de uma única escola que tem como objetivo promover a reflexão e o contato com as diferenças, seja a partir da presença física de estudantes com características diversas, seja pela abordagem do diferente a partir dos momentos de brincar ou de leitura inseridos no cotidiano escolar, seja pela própria oferta de brinquedos e mobiliário que remetem à diferença e ainda pela orientação profissional de que os professores e funcionários devem atentar para a mediação que favoreça um contato positivo ante as relações em que acontecem o encontro com as diferenças. Então faz-se necessário investigar o papel da escola e das condutas escolares no desenvolvimento do preconceito em crianças pequenas, replicando os instrumentos utilizados nesta pesquisa em outros ambientes escolares.

Concluindo os achados desta pesquisa encontra-se mais perguntas e indicações de continuidade investigativa do que respostas, como já era esperado para um tema tão complexo quanto o desenvolvimento do preconceito em crianças com idades entre três e quatro anos. Daqui a pesquisa aponta para desdobramentos que visam investigar a importância da inclusão escolar como fator para minimizar a formação do preconceito em crianças pequenas; o papel da escola, da sociedade e dos adultos de maneira geral na mediação da relação entre crianças com e sem deficiência como uma forma também de minimizar a formação do preconceito em criança pequenas; os efeitos das campanhas anti preconceito na formação da criança, comparando pesquisas antigas e atuais com relação à manifestação do preconceito em crianças. Também aponta para a necessidade de replicar os instrumentos utilizados nesta pesquisa em outros sujeitos de pesquisa que estejam imersos em diferentes ambientes e realidades sociais, ampliando a confiabilidade do instrumento e podendo inclusive validá-lo como uma escala que se proponha a medir o índice de manifestação do preconceito em crianças pequenas, instrumento que ainda não possuímos e que seria de grande valia para os estudos sobre o preconceito. Mas para além de tantos questionamentos, também conclui-se a pesquisa com um importante norte que pode auxiliar a direcionar outras pesquisas 
sobre o desenvolvimento preconceito em crianças, apontando a tendência de que crianças com idade entre três e quatro anos ainda não internalizaram as formas de manifestação do preconceito o que pode indicar essa como uma idade ótima para o início do trabalho com crianças, com vistas a minimizar as formações preconceituosas. 


\section{Referências bibliográficas}

Aboud, F. E. et al (2012). Intervencions . Developmental Review, 32 pp. 307-336. Disponível em www.elsevier.com/locate/dr

Adorno, T. W.; Brunswik, E.F.; Levinson, D.J.;Sanford, R.N. (1965). La personalidad autoritária. Buenos Aires: Proyección

Adorno T. W. (1972). Teoría de la seudocultura. In: Filosofia $y$ Superstición. Madrid: Alianza editorial.

Adorno, T. W. (1996). Teoria da Semicultura. Em: Educação e Sociedade, ano XVII, n.56, dezembro de 1996, p.388 a 411.

Adorno, T. W. (2006). Educação após Auschwitz. Em: Educação e Emancipação. Rio de Janeiro: Paz e Terra.

Adorno, T. W. (2006 A). Educar para quê?. Em: Educação e Emancipação. Rio de Janeiro: Paz e Terra.

Adorno, T. W. (2006 B). A educação contra a barbárie. Em: Educação e Emancipação. Rio de Janeiro: Paz e Terra.

Agambem, G. (2012) Infância e História: ensaio sobre a destruição da experiência. Belo Horizonte: Editora UFMG

Allport, G. W. (1979). The nature of prejudice. New York: Basic Books.

Almeida, S.S.M. (2012). Análise do autoconceito e do autocontrole de crianças negras a partir da identidade social. Dissertação de mestrado. Programa de pósgraduação em psicologia social do centro de ciências de educação e ciências humanas. Universidade Federal de Sergipe. 
Antunes, D. C. (2008). Razão Instrumental e Preconceito: Reflexões sobre o Bullying. Dissertação de mestrado. Programa de pós- graduação em Educação do Centro de Educação e Ciências Humanas da Universidade Federal de São Carlos.

Amaral, A. L. (1992). Espelho convexo: o corpo desviante no imaginário coletivo pela voz da Literatura Infanto- Juvenil. Tese de doutorado. Instituto de Psicologia da Universidade de São Paulo.

Batista, M. W. e Enumo, S. R. F. (2004). Inclusão escolar e deficiência mental: análise da interação social entre companheiros. Em: Estudos de Psicologia, 9(1), pp. 101-111.

Barreiros, R. C. e Vieira, N.R.F. (2011) identidade cultural na literatura infantil afrobrasileira. Anais do XI congresso luso afro brasileiro de ciências sociais. Disponível em: xiconlab.eventos.dype.com.br

Benjamin, W. (1933) Experiência e Pobreza. Em: (1996) Obras

Escolhidas: magia e técnica, arte e política. São Paulo: Editora brasiliense.

Benjamin, W. (1936) O narrador. Considerações sobre a obra de Nikolai Leskov. Em: (1996) Obras Escolhidas: magia e técnica, arte e política.

São Paulo: Editora brasiliense.

Benjamin, W. (1928) Brinquedo e Brincadeira. Observações sobre uma obra monumental. Em: (1996) Obras Escolhidas: magia e técnica, arte e política. São Paulo: Editora brasiliense.

Cabral, F. A. (2011) Inclusão escolar no ensino fundamental: estudo das relações sociais entre os alunos com e sem deficiência intelectual. Dissertação de mestrado. Programa de estudos pós-graduados em Educação: história, política, sociedade. Pontifícia Universidade Católica de São Paulo.

Carvalho, L. R. de (1997). Diversidade das ideias maternas: o que pensam as mães sobre a educação e o desenvolvimento de seus filhos. Em: MONTEIRO, Maria 
Benedicta e Castro, P. (1997). Cada Cabeça sua Sentença: ideias dos adultos sobre as crianças. Oeiras: Celta editoria.

Casco, R. (2007) Autoridade e formação: relações sociais na sala de aula e no recreio. Tese de doutorado, Programa de Estudos Pós-Graduados em Educação: história, política e sociedade, Pontifícia Universidade Católica de São Paulo.

Clark, K. B. (1963). Prejudice and you child. New Hampshire: New England Univ PR.

Costello, K. e Hordson, G. (2012) Explaining dehumanization among children: the interspecies modelo of prejudice. British Journal of Social Psychology. Disponível em: www.wileyonlinelibrary.com

Crochík, J. L. (1990). A personalidade narcisista segundo a Escola de Frankfurt e a ideologia da racionalidade tecnológica. Em: Revista Psicologia USP, dez. 1990, v.1,n.2.

Crochík, J. L. (2003) O desencanto sedutor: a ideologia da racionalidade tecnológica. Em: Inter-Ação: Revista da Faculdade de Educação UFG, jan/jun 2003, p. 15-35.

Crochík, J. L. (2006). Preconceito, indivíduo e cultura. São Paulo: Casa do Psicólogo.

Crochík, J. L. (2000). Teoria Crítica da sociedade e estudos sobre o preconceito. Revista Psicologia Política, p.67 - 99

Crochík, J. L. (2004). Manifestações de preconceito em relação às etnias e aos deficientes. Em: CROCHÍK, José Leon (coordenador) (2011). Preconceito e Educação Inclusiva. Brasília: SDH/PR.

Crochík, J. L., Feller, C.C., Lima e Dias, M A.,Fefferman M., Nascimento, R.B. e Casco, R. (2013) Educação inclusiva: escolha e rejeição entre alunos. Psicologia \& Sociedade, 25(1), p.174-184. 
Cruz, S. H. V. C. (2015). Considerações acerca da discriminaçãoo étnico-racial em crianças pequenas. Em: Anais da 37 reunião nacional da ANPEd, de 04 a 08 de outubro de 2015, em UFSC, Florianópolis.

Cruz, T. M. (2014). Espaço escolar e discriminação: significados de gênero e raça entre crianças. Em: Educação em revista, vol. 30, n.1, Belo Horizonte, janeiro/março de 2014.

Doria, A. S. (2008) O preconceito em foco: analise das obras literárias infantojuvenis. São Paulo: Paulinas.

Fazzi, R. de C.. (2009) Sociologia da Infância: reflexões teóricas e metodológicas de um campo em construção. Disponível em: anais do 33 encontro anual da ANPOCS, www.portal.anpocs.org. Acesso em:13/novembro/2014.

Fernandes, S.C.S; Almeida, S.S.M. e Nascimento, C.B.S (2008). Análise do preconceito racial em uma amostra de crianças brancas de 58 anos de idade. Psico, Porto Alegre, PUCRS, v. 39, n.4,pp.441-447.

França, D. X. e Monteiro, M. B. (2004) A expressão das formas indirectas de racismo na infância. Análise Psicologica, 4 (XXII), p. 705 a 720.

Freud, S. 1905. Três ensaios sobre sexualidade. . In: 2006. Freud: Obras Completas. Rio de Janeiro: Imago.

Freud, S. (1920). Além do princípio do prazer. In: (2006). Freud: Obras Completas. Rio de Janeiro: Imago.

Freud, S. (1930). O mal estar da civilização. In: (2006). Freud: Obras Completas. Rio de Janeiro: Imago.

Galeão -Silva, L. G. (2007). Adesão ao fascismo e preconceito contra negros: um estudo com universitários na cidade de São Paulo. Tese de doutorado, Programa de 
Estudos Pós-Graduados em Psicologia Social, Pontifícia Universidade Católica de São Paulo.

Gómez, A. e Huici, C. (2008). Vicarious intergroup contact and the role os authorities in prejudice reduction. The Spanish jornal of psychology. Vol 11, n. 1, pp 103-114.

Horkheimer, M. (1936). Autoridade e Família. Em: (1990). Teoria Crítica I. São Paulo: Perspectiva- Editora da Universidade de São Paulo.

Horkheimer M. e Adorno T. W. (2006). O Conceito de Esclarecimento. Em: e Dialética do Esclarecimento. Rio de Janeiro: Jorge Zahar.

Horkheimer M. e Adorno T. W. (1973). Preconceito. Em: e (orgs). Temas Básicos de Sociologia. São Paulo: Cultrix.

Horkheimer M. e Adorno T. W. (1973A). Família. Em: e (orgs). Temas Básicos de Sociologia. São Paulo: Cultrix.

Kawashima, R.A. (2007). Condutas de discriminação entre crianças da educação infantil. Dissertação de mestrado. Programa de Pós Graduação em Educação. Universidade Estadual Paulista “Julio de Mesquita Filho", Campus de Marília.

Marcuse, H. (1969). Eros e civilização: uma interpretação filosófica do pensamento de Freud. Rio de Janeiro: Zahar.

Martins, J. de S. (1997) A exclusão social e a nova desigualdade. São Paulo: Paulus, editorial.

Martins, R. (2006). Teste da boneca no Brasil Em: http://www.youtube.com/watch?v=3o1aOF6PeWM Acesso em 18/04/2014.

Oliveira, E.F.R.L (2007). Atitudes dos alunos brancos em relação a alunos negros. Dissertação de mestrado. Mestrado em Relações Interculturais. Universidade Aberta. Porto. 
Pedrossian, D.R.S, Crochík, J. L., Meneses, B. M, Morais, J.P.P, Lima e Costa, T., Samper, T.Q., Superti, T., Oliveira, T.M. e Custódio, T. O. (2008). Um estudo do preconceito e de atitudes em relação à educação inclusiva. Em: Crochík, J. L. (coordenador) (2011). Preconceito e Educação Inclusiva. Brasília: SDH/PR.

Peters, M. F. (1985). Racial socialization of Young black children. In: McADOO, H. P. (2002). Black children: social, educational, and parental enviroments. Califórnia: Sage Publications Inc.

Piccolo, G. M. (2011). Educação infantil: Análise da manifestação social do preconceito na atividade principal de jogos. Em: Educ soc Campinas, v.32, n. 114, p. 205 à 221. Disponível em: www.cedes.unicamp.br

Porter, J. D. R. (1973). Black Child, White Child - The development of racial atitudes. Massachusetts: Harvard University Press.

Rodrigues, R. B.; Monteiro, M.B. e Rutland, A. (2010) Cada cabeça, duas sentenças: aprendizagem e activação das normas anti-racistas e do favoritismo endogrupal ao longo da infância e avaliações inter-raciais em crianças brancas de origem lusa. Anais do VII Simpósio Nacional de Investigação em Psicologia da Universidade do Minho, pp. 3459 a 3470.

RutlandU, A.; Killen, M.; Abrams, D. (2010). A nem social-cognitive developmental perspective on prejudice: the interplay between morality and group identity. Perspectives on Psychological Science. Pp. 279-291. Disponível em: http://pps.sagepub.com/content/5/3/279

Saramago, J. (1998) O Conto da ilha desconhecida. São Paulo: Companhia das letras.

Sekkel ,M. C.; Zanelatto, R. e Brandão, S. de B. (2009) Uma questão sobre a educação inclusiva: expor-se ou resguardar-se?. Em: Psicologia ciência e profissão, 2010, p. 296- 307. 
Siegel, S. (1979) Estatística não- paramétrica. São Paulo: Editora McGraw-Hill do Brasil.

Ventura, P. e Monteiro, M. B. (1997). Sentença dos pais, escolas para os filhos. Em: Monteiro, M. B. e Castro, P. (1997). Cada Cabeça sua Sentença: ideias dos adultos sobre as crianças. Oeiras: Celta editoria.

Vermelho, S. C. S. D. (2003) Educação e virtualização: as mídias e a formação do indivíduo. Tese de doutorado, Programa de estudos pós-graduados em Educação: história, política, sociedade. Pontifícia Universidade Católica de São Paulo. 
APÊNDICE I - Modelo do termo de consentimento livre e esclarecido.

\section{TERMO DE CONSENTIMENTO LIVRE E ESCLARECIDO - TCLE}

1. A criança por quem você é responsável está sendo convidado a participar da pesquisa intitulada: Investigação da manifestação do preconceito em crianças pequenas.

2. A participação não é obrigatória e a qualquer momento pode haver desistência de participar e retirada do seu consentimento. Sua recusa não trará nenhum prejuízo em sua relação com o pesquisador ou com a instituição.

3. O objetivo deste estudo é compreender se características de manifestação do preconceito podem ser notadas já desde a primeira infância, em crianças de 3 a 4 anos de idade. Para isso pretende-se estabelecer a relação entre o preconceito quando verificado na criança e o meio em que ela está inserida. $E$ verificar se a criança muda suas posições frente ao diferente quando possui contato com ele, mediado positivamente pelo adulto.

4. A participação do seu filho nesta pesquisa consistirá participar de uma brincadeira com bonecos representantes das cores de pele branca e negra, bem como representantes de pessoas com presença ou ausência de deficiência. A brincadeira será direcionada pela pesquisadora e ocorrerá na escola em que a criança estuda, durante o horário da escola, conforme previamente combinado com a direção da escola. Também será realizada uma observação de 10 minutos na sala de aula em que a criança estuda no momento do brincar livre entre as crianças, sem a intervenção da pesquisadora.

5. Você e a criança não correm riscos de saúde ou de prejuízo psíquico com a realização desta pesquisa. Não há risco de constrangimento moral ante as escolhas da criança no momento do brincar. 
6. As informações obtidas através dessa pesquisa serão confidenciais e asseguramos o sigilo sobre sua participação.

7. Os dados não serão divulgados de forma a possibilitar sua identificação e da instituição e dos indivíduos participantes.

8. Em caso de publicação dos resultados desta pesquisa, reitera-se a confidencialidade dos dados e a alteração de quaisquer elemento que possibilite a identificação da instituição ou dos sujeitos participantes da pesquisa.

9. Você receberá uma cópia deste termo onde consta o telefone e o endereço do pesquisador principal, podendo tirar suas dúvidas sobre o projeto e sua participação, agora ou a qualquer momento.

10. Este termo deverá ser assinado e datado em sua última folha e rubricado em todas as suas páginas. 
DADOS DO PESQUISADOR PRINCIPAL (ORIENTANDO)

Fernanda Araujo Cabral

Nome

Assinatura

Endereço completo do pesquisador:

Av. Prof. Mello Moraes, 1721, Bloco A, sala 168, São Paulo, SP, CEP: 05508-030

Telefone de contato: 11-3091-4356 ou 11- 3091-4185

E-mail de contato: fe.araujo.cabral@usp.broufe.arau@uol.com.brou

fernanda.fmu@gmail.com

Endereço do comitê de Ética em Pesquisa com Seres Humanos do IPUSP:

Av. Professor Mello Moraes, 1721, bloco G, 2 andar, sala 27, São Paulo, SP, CEP: 05508-030

Telefone de contato: 11- 3091-4182

E-mail de contato: ceph@usp.br

Declaro que entendi os objetivos de minha participação na pesquisa e concordo em participar.

de de 20

Sujeito da pesquisa *

Pai / Mãe ou Responsável Legal * 
Data da aplicação 1 Grupo TURMA:

\begin{tabular}{|c|c|c|}
\hline Situação problema & Padrão de resposta e pontuação & Observações \\
\hline $\begin{array}{l}\text { Situação } 1 \text { - escolha } \\
\text { dos papéis para os } \\
\text { personagens }\end{array}$ & 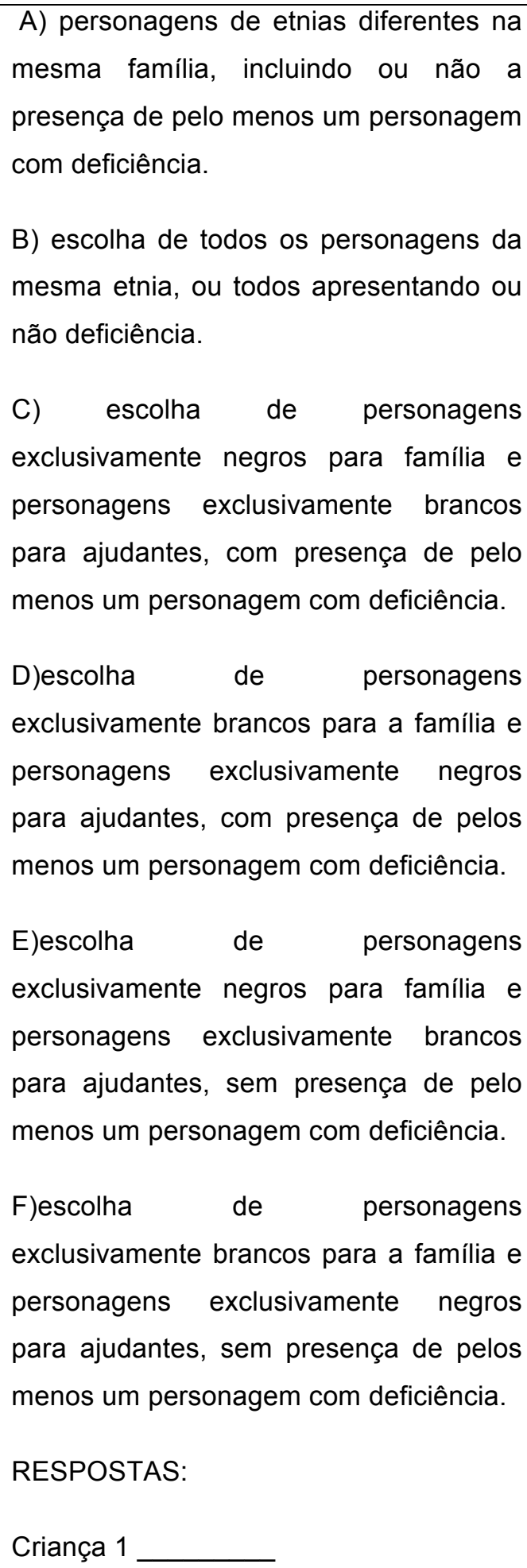 & \\
\hline
\end{tabular}




\begin{tabular}{|c|c|}
\hline & $\begin{array}{l}\text { Criança } 2 \\
\text { Criança } 3 \\
\text { Criança } 4 \\
\text { Criança } 5\end{array}$ \\
\hline $\begin{array}{l}\text { Situação } 2 \text { - Escolha de } \\
\text { um dos personagens } \\
\text { criança para derrubar o } \\
\text { aparelho celular de um } \\
\text { dos personagens que } \\
\text { representa um adulto } \\
\text { cuidador. }\end{array}$ & $\begin{array}{l}\text { A) Criança branca } \\
\text { B) Criança negra } \\
\text { C) Criança branca com deficiência } \\
\text { D) Criança negra com deficiência } \\
\text { RESPOSTAS: } \\
\text { Criança } 1 \\
\text { Criança } 2 \\
\text { Criança } 3 \\
\text { Criança } 4 \\
\text { Criança } 5\end{array}$ \\
\hline $\begin{array}{l}\text { Situação 3- Seleção da } \\
\text { punição para o } \\
\text { personagem que } \\
\text { representa a criança } \\
\text { que derrubou o aparelho } \\
\text { celular, concordância e } \\
\text { obediência. }\end{array}$ & $\begin{array}{l}\text { A) Não haverá punição. } \\
\text { B)Conversar ou castigo, sem concordar } \\
\text { ou obedecer. } \\
\text { C) conversa ou castigo, concordando e } \\
\text { sem obedecer. } \\
\text { D)conversa ou castigo, concordando e } \\
\text { obedecendo. } \\
\text { E) Bater, sem concordar. } \\
\text { F) Bater, com concordância. } \\
\text { RESPOSTAS: } \\
\text { Criança } 1 \\
\text { Criança } 2\end{array}$ \\
\hline
\end{tabular}




\begin{tabular}{|c|c|}
\hline & $\begin{array}{l}\text { Criança } 3 \\
\text { Criança } 4 \\
\text { Criança } 5\end{array}$ \\
\hline $\begin{array}{l}\text { Situação 4- } \\
\text { um doleção de } \\
\begin{array}{lr}\text { para realizar } & \text { uma } \\
\text { produção } & \text { escolar } \\
\text { reconhecida } & \text { pelos } \\
\text { adultos. } & \end{array}\end{array}$ & $\begin{array}{l}\text { A) Criança negra com deficiência } \\
\text { B) Criança branca com deficiência. } \\
\text { C) Criança negra } \\
\text { D) Criança branca } \\
\text { RESPOSTAS:Criança } 1 \\
\text { Criança } 2 \\
\text { Criança } 3 \\
\text { Criança } 4 \\
\text { Criança } 5\end{array}$ \\
\hline $\begin{array}{lr}\text { Situação } & 5 \\
\text { Determinação } & \text { de } \\
\text { punição para um } & \text { que } \\
\text { personagem } & \text { que } \\
\text { representa um filho que } \\
\text { desobedece aos pais. }\end{array}$ & $\begin{array}{l}\text { A) Não haverá punição. } \\
\text { B) Conversar com a criança. } \\
\text { C) Colocar a criança de castigo. } \\
\text { D) Bater na criança } \\
\text { E) Quebrar algo da criança } \\
\text { F) Excluir o personagem da brincadeira } \\
\text { RESPOSTAS: } \\
\text { Criança } 1 \\
\text { Criança } 2 \\
\text { Criança } 3 \\
\text { Criança } 4 \\
\text { Criança } 5\end{array}$ \\
\hline $\begin{array}{lll}\text { Situação } & 6 & - \\
\text { Determinação } & & \text { de }\end{array}$ & A) Não haverá punição. \\
\hline
\end{tabular}




\begin{tabular}{|c|c|}
\hline $\begin{array}{lrr}\text { punição } & \text { para } & \text { o } \\
\text { personagem } & \text { filho } & \text { da } \\
\text { ajudante } & \text { que } & \text { a } \\
\text { desobedece. } & & \end{array}$ & $\begin{array}{l}\text { B) Conversar com a criança. } \\
\text { C) Colocar a criança de castigo. } \\
\text { D) Bater na criança } \\
\text { E) Quebrar algo da criança } \\
\text { F) Excluir o personagem da brincadeira } \\
\text { RESPOSTAS: } \\
\text { Criança } 1 \\
\text { Criança } 2 \\
\text { Criança } 3 \\
\text { Criança } 4 \\
\text { Criança } 5\end{array}$ \\
\hline $\begin{array}{l}\text { Situação } 7 \text { - Escolha de } \\
\text { atitudes que os } \\
\text { personagens que } \\
\text { representam crianças } \\
\text { devem tomar } \\
\text { relação a com } \\
\text { crianças que tem } \\
\text { comportamentos } \\
\text { considerados errados } \\
\text { pelos adultos. }\end{array}$ & $\begin{array}{l}\text { A)Não haverá punição. } \\
\text { B)Conversar com a criança. } \\
\text { C) Colocar a criança de lado na } \\
\text { brincadeira. } \\
\text { D) Bater na criança } \\
\text { E) Fazer um grupo para excluir a criança. } \\
\text { F)Excluir o personagem da brincadeira } \\
\text { RESPOSTAS: } \\
\text { Criança } 1 \\
\text { Criança } 2 \\
\text { Criança } 3 \\
\text { Criança } 4 \\
\text { Criança } 5\end{array}$ \\
\hline $\begin{array}{l}\text { Situação } 8 \text { - Averiguar } \\
\text { os papéis que cada } \\
\text { boneco que representa }\end{array}$ & $\begin{array}{l}\text { A) Não há diferença entre papéis. } \\
\text { B) Identificar como líder a criança do mesmo }\end{array}$ \\
\hline
\end{tabular}




\begin{tabular}{|c|c|}
\hline $\begin{array}{l}\text { uma criança assume na } \\
\text { representação de uma } \\
\text { brincadeira entre as } \\
\text { crianças. }\end{array}$ & $\begin{array}{l}\text { sexo que o do sujeito de pesquisa. } \\
\text { C) Identificar como líder crianças com } \\
\text { deficiência. } \\
\text { D) Identificar como líder crianças negras. } \\
\text { E)Identificar como líder crianças brancas. } \\
\text { F) Excluir algum personagem da brincadeira. } \\
\text { RESPOSTAS: } \\
\text { Criança } 1 \\
\text { Criança } 2 \\
\text { Criança } 3 \\
\text { Criança } 4 \\
\text { Criança } 5\end{array}$ \\
\hline $\begin{array}{l}\text { Situação } 9 \text { - Inserção } \\
\text { de um personagem com } \\
\text { deficiência, caso esse } \\
\text { não tenha sido } \\
\text { previamente escolhido } \\
\text { pela criança e análise } \\
\text { da atribuição do papel } \\
\text { que a criança dará. }\end{array}$ & $\begin{array}{l}\text { A) Não há diferença entre os papéis. } \\
\text { B)Cuidar do personagem. } \\
\text { C) Colocar impossibilidades para o } \\
\text { personagem. } \\
\text { D) Agredir física ou verbalmente o } \\
\text { personagem. } \\
\text { E) Aceitar o personagem, mas não incluí-lo } \\
\text { na brincadeira após a intervenção do } \\
\text { pesquisador. } \\
\text { F) Recusar a participação do personagem. } \\
\text { RESPOSTAS: } \\
\text { Criança } 1 \text { Criança } 5 \\
\text { Criança } 2 \\
\text { Criança } 3\end{array}$ \\
\hline
\end{tabular}


APÊNDICE III- Ficha de validação de instrumento de pesquisas

Os senhores estão sendo convidados a validar a elaboração do procedimento metodológico da pesquisa intitulada Investigação da manifestação do preconceito em crianças pequenas, que será realizada como parte do processo de doutoramento da psicóloga Fernanda Araujo Cabral, no programa de pós graduação em psicologia da Universidade de São Paulo, departamento de Psicologia da Aprendizagem, do Desenvolvimento e da Personalidade, sob a orientação do Professor José Leon Crochík. O objetivo deste estudo é compreender se características do preconceito podem ser notadas já desde a primeira infância, em crianças de 3 a 4 anos de idade. Para isso pretende-se estabelecer a relação entre o preconceito quando verificado na criança e o meio em que ela está inserida. Bem como verificar se a criança muda suas posições frente ao diferente quando possui contato com ele.

O instrumento apresentado na pesquisa consiste em adaptação da escala $F$ elaborada por Adorno et all (1965) na pesquisa intitulada "A personalidade autoritária".

A escala $F$, em sua versão traduzida, foi composta por 28 questões; alguns dos fatores utilizados na escala foram:

1. Índice de adesão aos valores impostos pela classe média, o que foi denominado como convencionalismo.

2. Submissão à autoridade.

3. Necessidade de controlar os indivíduos que não se submetem aos valores convencionais utilizando a agressividade, o que denominou de agressividade autoritária.

4. Posição de oposição à manifestação dos sentimentos e de valores subjetivos.

5. Crença em poderes sobrenaturais.

6. Identificação com as figuras que representam o poder e necessidade de se submeter a estas.

7. Hostilidade com a humanidade.

8. Crença de que o mundo pode submeter a castigos, ou mesmo projeção dos impulsos destrutivos inconscientes.

9. Preocupação exagerada com os impulsos sexuais.

Para a adaptação da escala será proposta uma situação lúdica para as crianças com a utilização de 16 bonecos de pano representando: 
- Um homem, uma mulher, um menino e uma menina da etnia branca e sem deficiências.

- Um homem, uma mulher, um menino e uma menina da etnia negra e sem deficiências

- Um homem, uma mulher, um menino e uma menina da etnia branca, todos com amputação de membro inferior.

- Um homem, uma mulher, um menino e uma menina da etnia negra, todos com amputação de membro inferior.

As situações problemas apresentadas no momento lúdico serão favorecendo a interação entre a criança e a pesquisadora da seguinte forma:

Os bonecos serão dispostos de forma aleatória para não caracterizar uma família já pré-estabelecida e estarão espalhados para garantir que a criança possa visualizar todas as possibilidades de escolhas. A brincadeira será direcionada pela pesquisadora que explicará à criança que irão brincar de casinha e que a criança primeiro terá de escolher dois bonecos para cuidar das crianças e dois bonecos para que representem os filhos, um boneco para representar a ajudante da casa e um boneco para representar o filho dessa ajudante.

A escolha dos padrões familiares será a primeira situação problema proposta para a criança, a partir desta escolha serão expostas outras situações problema e observadas as reações da criança durante o brincar, são elas:

Situação 2 - Escolha de um dos personagens criança para derrubar o aparelho celular de um dos personagens que representa um adulto cuidador.

Situação 3 - Seleção da punição para o personagem que representa a criança que derrubou o aparelho celular, averiguação de concordância com a punição e de capacidade de resignação ante esta.

Situação 4- Seleção de um dos personagens para realizar uma produção escolar reconhecida pelos adultos.

Situação 5 - Determinação de punição para um personagem que representa um filho que desobedece aos pais.

Situação 6 - Determinação de punição para o personagem filho do ajudante que o desobedece. 
Situação 7 - Escolha de atitudes que os personagens que representam crianças devem tomar com relação a outras crianças que tem comportamentos considerados errados pelos adultos.

Situação 8 - Averiguar os papéis que cada boneco que representa uma criança assume na representação de uma brincadeira entre as crianças.

Situação 9 - Inserção de um personagem com deficiência ou negro em situação de vantagem, caso esse não tenha sido previamente escolhido dessa forma pela criança e análise da atribuição do papel que a criança dará.

Solicito sua ajuda primeiramente para averiguar se as situações problema propostas conseguem avaliar as dimensões propostas na escala $F$ conforme 0 quadro abaixo. Para tanto peço que preencham a segunda coluna do quadro abaixo atribuindo uma ou mais situação problema, dentre as estipuladas acima, que julguem capaz de dimensionar a situação problema.

\begin{tabular}{|l|l|}
\hline Itens avaliados pela Escala F & $\begin{array}{l}\text { Situação (s) problema } \\
\text { correspondente }\end{array}$ \\
\hline Convencionalismo & \\
\hline Submissão à autoridade & \\
\hline Agressividade autoritária & \\
\hline Identificação com figuras de poder & \\
\hline
\end{tabular}




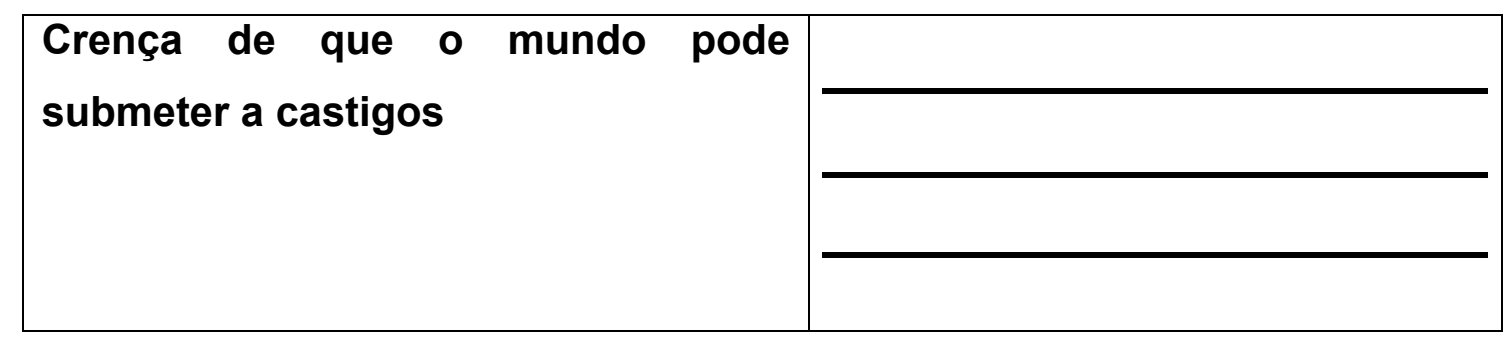

A segunda solicitação é para que os senhores possam valorar as possibilidades de respostas das crianças para cada situação problema quanto à demonstração de preconceito, atribuindo uma nota de 0 a 5 , de forma que 0 seja atribuído para a resposta que denote menos preconceito e 5 para a que denote mais preconceito, incluído as gradações 1,2,3 e 4 aumentando o valor atribuído para as situações que julgarem mais preconceituosas. Caso julguem pertinente, por favor fazer observações na terceira coluna. A finalidade dessa atribuição de valores é validar a proposição de valores elaborada no instrumento.

\begin{tabular}{|c|c|c|}
\hline Situação problema & $\begin{array}{l}\text { Padrão de } \quad \text { resposta e } \\
\text { pontuação }\end{array}$ & Observações \\
\hline $\begin{array}{lr}\text { Situação } & 1 \\
\text { escolha dos } & \text { papéis } \\
\text { para } & \text { os } \\
\text { personagens } & \end{array}$ & $\begin{array}{l}\text { (_) personagens de etnias } \\
\text { diferentes na mesma família, } \\
\text { incluindo ou não a presença de } \\
\text { pelo menos um personagem com } \\
\text { deficiência. } \\
\text { (_ escolha de todos os } \\
\text { personagens da mesma etnia, ou } \\
\text { todos apresentando ou não } \\
\text { deficiência. } \\
\text { (_) escolha de personagens } \\
\text { exclusivamente negros para } \\
\text { família personagens } \\
\text { exclusivamente brancos para } \\
\text { ajudantes, com presença de pelo } \\
\text { menos um personagem com } \\
\text { deficiência. } \\
\text { ( }) \text { escolha de personagens }\end{array}$ & \\
\hline
\end{tabular}




\begin{tabular}{|c|c|}
\hline & 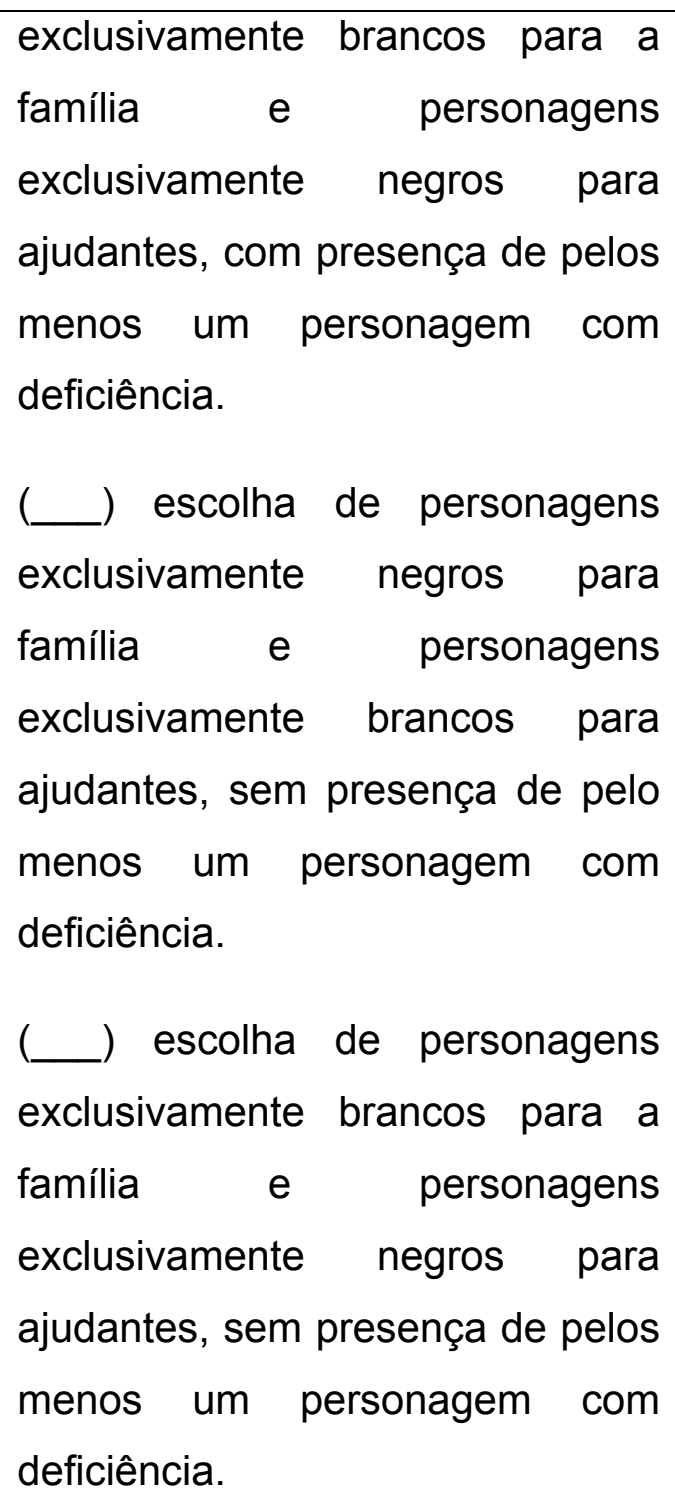 \\
\hline $\begin{array}{l}\text { Situação } 2 \\
\text { Escolha de um dos } \\
\text { personagens } \\
\text { criança para } \\
\text { derrubar o aparelho } \\
\text { celular de um dos } \\
\text { personagens que } \\
\text { representa um } \\
\text { adulto cuidador. }\end{array}$ & 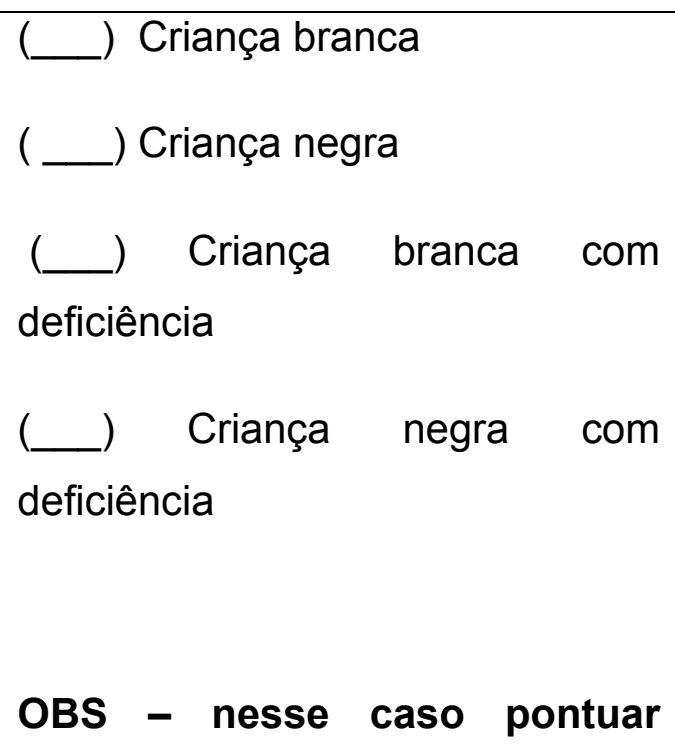 \\
\hline
\end{tabular}




\begin{tabular}{|c|c|}
\hline & apenas de 0 a 3 \\
\hline $\begin{array}{l}\text { Situação } 3- \\
\text { Seleção da punição } \\
\text { para o personagem } \\
\text { que representa a } \\
\text { criança que } \\
\text { derrubou o aparelho } \\
\text { celular, } \\
\text { concordância e } \\
\text { obediência. }\end{array}$ & $\begin{array}{l}\text { (__ Não haverá punição. } \\
\text { concordar ou obedecer. } \\
\text { (__ conversar ou castigo, sem } \\
\text { concordando e sem obedecer. } \\
\left(\_ \text {c conversa ou castigo, }\right. \\
\text { concordando e obedecendo. } \\
\left(\_ \text {B Bater, sem concordar. }\right. \\
\text { (__ Bater, com concordância. }\end{array}$ \\
\hline $\begin{array}{lr}\text { Situação } & 4- \\
\text { Seleção de um dos } \\
\text { personagens } & \text { para } \\
\text { realizar } & \text { uma } \\
\text { produção escolar } \\
\text { reconhecida } & \text { pelos } \\
\text { adultos. }\end{array}$ & $\begin{array}{l}\left(\_ \text {Criança negra com }\right. \\
\text { deficiência } \\
\left(\_\right) \text {Criança branca com } \\
\text { deficiência. } \\
\left(\_ \text {Criança negra }\right. \\
\left(\_\right) \text {Criança branca } \\
\text { OBS - nesse caso pontuar } \\
\text { apenas de } 0 \text { a } 3\end{array}$ \\
\hline $\begin{array}{lr}\text { Situação } & 5 \\
\text { Determinação } & \text { de } \\
\text { punição para um } \\
\text { personagem que } \\
\text { representa um } \\
\text { que dilho } \\
\text { desobedece }\end{array}$ & $\begin{array}{l}\text { (_ Não haverá punição. } \\
(\ldots \text { ) Conversar com a criança. } \\
\text { c__ Colocar a criança de } \\
\text { castigo. } \\
\text { (_ Bater na criança }\end{array}$ \\
\hline
\end{tabular}




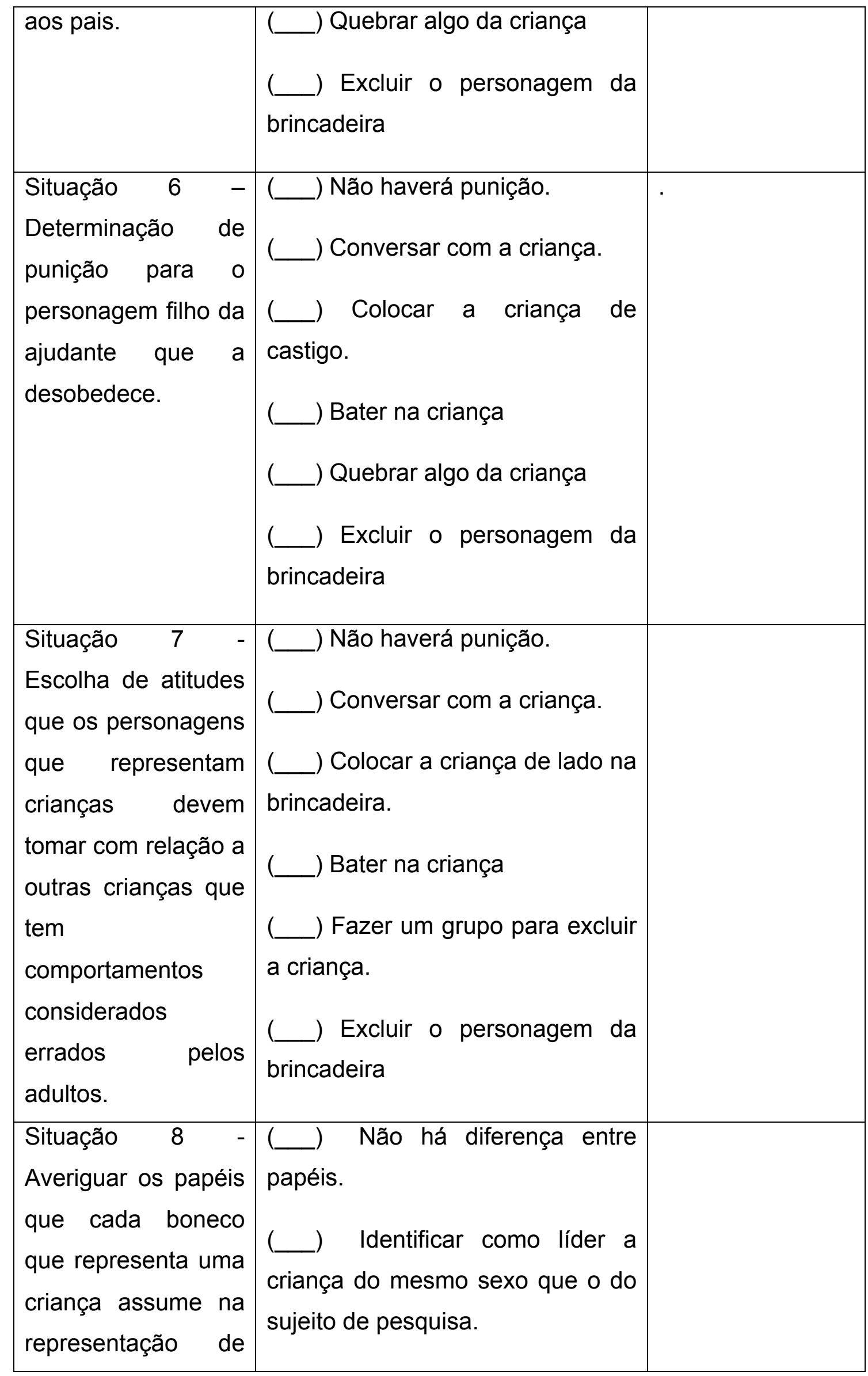


APÊNDICE IV - Descrição da observação do momento lúdico

\title{
Crianças participantes do GRUPO I - crianças que possuem contato em sala de aula com pessoas que possuem deficiência ou cor de pele negra
}

\author{
Subgrupo A1- composto por 5 crianças
}

Crianças manipulam todos os brinquedos. Umas pegam da mão das outras mostrando curiosidade. Não discriminam cor ou presença e ausência de deficiência. Começam a dividir os bonecos entre elas. Uma menina pega uma boneca branca e com deficiência e começa a brincar de dar banho, logo todos vão fazendo o mesmo. Criança com diagnóstico de transtorno do espectro do autismo estava segurando uma boneca negra nas mãos, a batia na mesa; nesse momento começa a pegar todas as bonecas e puxar para ela. Outras crianças do grupo não falam nada, mas tiram bonecos da mão dela, criança com espectro do autismo grita e uma das meninas diz que nem todos os brinquedos serão para ele, tomando o brinquedo da mão da criança. Criança do espectro do autismo volta a bater boneca negra na mesa e demais crianças continuam atividade de dar banho nas bonecas. Algumas crianças brincam de dar comidas e outras brincam de pôr para dormir, não atribuem papéis diferenciados para crianças. Outra menina do grupo se aproxima da criança diagnosticada com espectro do autismo e diz que ela irá machucar a boneca e pega dizendo que deveria colocar para dormir, criança entrega a boneca e sai da brincadeira pegando outros brinquedos que estão pela sala. Aos poucos as crianças vão se dispersando e pegando outros materiais pela sala, por vezes levando consigo os bonecos com que estavam brincando.

\section{Subgrupo A2 - composto por 4 crianças}

Crianças exploram todos os bonecos sem distinção, pegam jogam para cima, comentam sobre os cabelos dizendo que são bonitos. Alguns começam a nomear dizendo ser o pai, e o outro atribui papel de mãe, vão formando uma família de maneira coletiva e sem diferenciar cor de pele ou presença e ausência de deficiência. Um dos meninos pergunta o que eram os "y " que estavam nos braços da boneca, outro menino responde que são cavalinhos e começam a brincar de fazer os bonecos andar a cavalo. Uma menina diz que o cavalo ajuda aos bonecos 
que não tem pernas andar, todos continuam brincando de cavalgar indiscriminadamente com os bonecos. Nessa brincadeira se dispersam pela sala. Uma das crianças começa a guardar os brinquedos, logo as demais que já estavam com outras tarefas voltam para auxiliar a guardar os bonecos.

\section{Subgrupo D1 - composto por 5 crianças}

Crianças pegam personagens e manipulam a todos indiscriminadamente, uma das meninas pergunta porque o boneco não tem pernas, não há resposta das outras crianças, então ela continua com o boneco e o coloca dentro da casinha junto com os outros. Crianças pegam bonecos e vão assumindo papéis na brincadeira, mulher branca é a mãe, homem negro com deficiência física o pai e dizem que o restante serão os filhos. Outra menina protesta e diz que precisa ter uma avó, pega uma boneca negra e coloca para ser a avó. Personagens adultos cuidam das crianças, dando banho ou comida. Um dos meninos pega todas as muletas que denomina como "y" e diz que vai sortear para entre as bonecas que eles designaram como filhos poderem brincar, uma das meninas responde que podem brincar, mas que é preciso ajudar aos bonecos que não tem pernas, porque se tirar os "y" deles irão cair.

\section{Subgrupo D2- composto por 5 crianças}

Brincam de colocar personagens dentro da casinha, fechar e tirar personagens de dentro da casinha. Jogam para cima, jogam personagens uns para os outros. Duas das crianças fecham a casinha com todos os personagens dentro e correm para baixo de um brinquedo. Um dos meninos chora chamando a professora e o outro fica observando. Como a professora não atende ao chamado, a criança que estava observando vai para o lugar onde os outros levaram os brinquedos e continuam a brincar, a criança que chorou se levanta e junta-se a brincadeira. Não atribuem papéis aos bonecos, apenas jogam um para o outro como se estivessem brincando com um dado. Uma das crianças que estava nesse grupo é a que possui suspeita de atraso do desenvolvimento, ela não pega os brinquedos, não fica no grupo, olha para o brinquedo, e anda em círculos. Em um determinado momento um dos meninos oferece um boneco a essa criança, ela segura e o solta no chão. Crianças começam a guardar os brinquedos na casinha e me entregam a casinha fechada com os bonecos. 


\section{Crianças participantes do GRUPO II- crianças que não possuem contato em sala de aula com pessoas que possuem deficiência ou cor de pele negra}

\section{Subgrupo B1- composto por 5 crianças}

Crianças manipulam todos os bonecos indiscriminadamente. O grupo de crianças dessa sala de aula era formado por oito crianças, de forma que dividimos em cinco crianças para o grupo B1 e três crianças para o grupo B2. Porém as crianças que deveriam brincar num segundo momento insistiam em brincar junto com o primeiro grupo e eram bem recebidas por este. Após algumas tentativas de reestabelecer a divisão mediadas pela professora, deixamos que todos brincassem juntos. Crianças pegavam os bonecos, tendência a pegar um número maior de bonecos para si, mas quando outra criança pedia elas dividiam. Deram colo para os bonecos atribuindoIhes papel de bebês, alimentaram com mamadeiras imaginárias. Um dos meninos pergunta porque alguns bonecos não tem pernas, outro menino responde "porque ela quebrou quando brincava" (apontando para a pesquisadora) e uma das meninas responde que não é isso, que eles não tem pernas para brincar de "cavalo de pau" referindo-se as muletas. Pegam muletas e brincam pela sala fingindo ser um cavalo para eles mesmos. Manipulam os bonecos e começam a tirar as roupas e depois decidem colocar novamente, explicando que estava frio. Quando são avisados que passaríamos para outra atividade, todos guardam os bonecos dentro da casinha, sem que nenhum adulto solicitasse.

\section{Subgrupo B2 - composto por 3 crianças}

As crianças que fariam parte desse grupo já haviam participado da brincadeira do grupo anterior, dessa forma quando convidadas a brincar novamente, olharam o material e disseram que já haviam brincado, não mostrando interesse por continuar a brincadeira. 
Subgrupo C1- composto por 6 crianças

Crianças dizem gostar da minha casinha, se referem à pesquisadora parabenizando porque o brinquedo era muito legal. Manipularam os bonecos, um dos meninos segura o boneco negro com deficiência física e fala que é o saci, todos concordam porque é o mês do folclore e lembram que viram histórias do saci, outro menino mostra que também tem sacis que são brancos. Um dos meninos pega todos os brinquedos e fecha-os dentro da casa, sob protesto dos demais, outro menino chora como resposta. Uma das meninas fica brava e diz ao menino que fechou a casa que a brincadeira não é só dele, abre a casa e dá um dos bonecos na mão da criança que estava chorando. Voltam a manipular brinquedos. Uma das meninas aproxima um boneco e uma boneca negra e diz que estão namorando, todos dão risada e um menino escolhe um boneco branco dizendo que é o filho deles. Crianças vão se dispersando a procura de outros brinquedos, deixando os bonecos dentro da casa.

\section{Subgrupo C2 - composto por 4 crianças}

Uma das meninas senta em frente a casa com bonecos e separa mais da metade para ela, explicando que aqueles serão dela. As demais crianças parecem não ouvir a decisão da primeira menina e vão pegando os bonecos para si, sejam os que estão próximos a ela, seja os que ela havia deixado para o grupo. Uma menina nota que alguns bonecos não tem pernas, um menino aponta para a pesquisadora e diz que eu estraguei o boneco porque os colocava na boca, outra menina retruca que não, que os bonecos são sem pernas porque existem pessoas que são sem pernas e os bonecos são como pessoas. Outra menina diz que os bonecos tem cabelos muito bonitos e de várias cores. Colocam os bonecos na casinha, cuidam, dão banho, sempre cada criança cuidando dos bonecos que separou para si. A primeira menina que separou os bonecos se levanta e vai brincar com outro material pela sala, os demais a seguem. Ao perceber que a pesquisadora foi guardando os bonecos, as crianças se aproximam e ajudam a guardar. 
APÊNDICE V - Síntese dos dados coletados na representação lúdica

Segue quadros que apresentam a compilação dos dados obtidos em cada sala de aula pesquisada no momento da representação lúdica. As colunas do quadro representam as respostas que cada criança forneceu para a situação problema correspondente indicada no cruzamento entre coluna e linha. Para saber qual a situação problema e a resposta fornecida pela criança, orienta-se consultar o quadro IX que descreve as situações problema e as pontuações atribuídas a cada resposta. Ainda como informação fornecida nos quadros temos a penúltima coluna do quadro com valores que correspondem ao total de pontos que cada situação problema obteve nas respostas da turma de crianças que representa. E por fim, a última linha representa a quantidade total de pontuação obtida pelas crianças que participaram da representação lúdica.

Apresentação dos dados individuais da coleta de dados na representação lúdica do grupo $A D$, turma A.

\begin{tabular}{|c|c|c|c|c|c|c|c|c|c|c|c|}
\hline $\begin{array}{l}\text { Ç̧/sit } \\
\text { prob }\end{array}$ & $\begin{array}{l}\mathrm{C} \zeta \\
\text { A1 }\end{array}$ & $\begin{array}{l}\mathrm{C}_{\mathrm{C}} \\
\mathrm{A} 2\end{array}$ & $\begin{array}{l}C_{\zeta} \\
\text { A3 }\end{array}$ & $\begin{array}{l}\text { Cद̧ } \\
\text { A4 }\end{array}$ & $\begin{array}{l}\text { Cद } \\
\text { A5 }\end{array}$ & $\begin{array}{l}\mathrm{CC} \\
\mathrm{A} 6\end{array}$ & $\begin{array}{l}\text { Cद } \\
\text { A7 }\end{array}$ & $\begin{array}{l}\text { Cद } \\
\text { A8 }\end{array}$ & $\begin{array}{l}\text { Cद } \\
\text { A9 }\end{array}$ & Total & Observações \\
\hline 1 & 0 & 0 & 0 & 0 & 0 & 0 & 0 & 0 & 0 & 0 & \\
\hline 2 & 0 & 3 & 1 & 0 & 3 & 0 & 0 & - & 0 & 7 & $\begin{array}{l}\text { Criança A4 responde que mãe } \\
\text { quebrou sozinha. Criança A7 } \\
\text { responde ninguém }\end{array}$ \\
\hline 3 & 0 & 1 & 0 & 0 & 1 & 5 & 0 & - & 0 & 7 & $\begin{array}{l}\text { Criança A8 (espectro do autismo) } \\
\text { não responde às questões }\end{array}$ \\
\hline 4 & 2 & 3 & 3 & 2 & 2 & 1 & 0 & - & 3 & 16 & \\
\hline 5 & 2 & 2 & 0 & 1 & 0 & 3 & 2 & - & 1 & 11 & \\
\hline 6 & 2 & 2 & 0 & 1 & 2 & 3 & 1 & - & 1 & 12 & \\
\hline 7 & 1 & 1 & 1 & 0 & 0 & 0 & 0 & - & 0 & 3 & \\
\hline 8 & 0 & 0 & 0 & 0 & 0 & 0 & 0 & - & 0 & 0 & \\
\hline 9 & - & - & - & - & - & - & - & - & - & - & Não se aplicou \\
\hline Total & 7 & 12 & 5 & 4 & 8 & 12 & 3 & 0 & 5 & & \\
\hline
\end{tabular}


Apresentação dos dados individuais da coleta de dados na representação lúdica do grupo $A D$, turma D.

\begin{tabular}{|c|c|c|c|c|c|c|c|c|c|c|c|c|}
\hline $\begin{array}{l}\text { Cç/sit } \\
\text { prob }\end{array}$ & $\begin{array}{l}\mathrm{C}, \\
\mathrm{D} 1\end{array}$ & $\begin{array}{l}\text { Cद } \\
\text { D2 }\end{array}$ & $\begin{array}{l}\mathrm{C} \text { G } \\
\text { D3 }\end{array}$ & $\begin{array}{l}\mathrm{C}_{\text {G }} \\
\mathrm{D} 4\end{array}$ & $\begin{array}{l}\text { Cद̧ } \\
\text { D5 }\end{array}$ & $\begin{array}{l}\text { Cद̧ } \\
\text { D6 }\end{array}$ & $\begin{array}{l}\text { Cद̧ } \\
\text { D7 }\end{array}$ & $\begin{array}{l}C_{6} \\
D 8\end{array}$ & $\begin{array}{l}\text { Ç } \\
\text { D9 }\end{array}$ & $\begin{array}{l}\text { Ç̧ } \\
\text { D10 }\end{array}$ & Total & Observaçōes \\
\hline 1 & 0 & 0 & 0 & 0 & 0 & 0 & 0 & 0 & 0 & 0 & 0 & \\
\hline 2 & 0 & 0 & 1 & 3 & 2 & 0 & 0 & 1 & 1 & 2 & 10 & \\
\hline 3 & 0 & 5 & 0 & 4 & 3 & 4 & 4 & 3 & 5 & 3 & 31 & \\
\hline 4 & 3 & 1 & 0 & 2 & 1 & 3 & 3 & 1 & 0 & 0 & 14 & \\
\hline 5 & 1 & 3 & 3 & 1 & 1 & 3 & 3 & 2 & 1 & 0 & 18 & \\
\hline 6 & 1 & 3 & 3 & 1 & 1 & 3 & 3 & 2 & 1 & 0 & 18 & \\
\hline 7 & 1 & 1 & 0 & 1 & 1 & 0 & 0 & 0 & 0 & 0 & 4 & \\
\hline 8 & 0 & 0 & 0 & 0 & 0 & 1 & 1 & 0 & 0 & 0 & 2 & \\
\hline 9 & - & - & - & - & - & - & - & - & - & - & - & Não se aplicou \\
\hline Total & 6 & 13 & 7 & 12 & 9 & 14 & 14 & 9 & 8 & 5 & & \\
\hline
\end{tabular}

Apresentação dos dados individuais da coleta de dados na representação lúdica do grupo BC, turma B.

\begin{tabular}{|c|c|c|c|c|c|c|c|c|c|c|}
\hline $\begin{array}{l}\text { Cc/sit } \\
\text { prob }\end{array}$ & $\begin{array}{l}\text { Ç } \\
\text { B1 }\end{array}$ & $\begin{array}{l}\mathrm{C} \zeta \mathrm{G} \\
\text { B2 }\end{array}$ & $\begin{array}{l}\mathrm{C}_{\text {G }} \\
\text { B3 }\end{array}$ & $\begin{array}{l}\mathrm{CC}_{\text {G }} \\
\text { B4 }\end{array}$ & $\begin{array}{l}\mathrm{C} \zeta \\
\text { B5 }\end{array}$ & 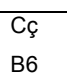 & $\begin{array}{l}\mathrm{CC}_{\text {G }} \\
\text { B7 }\end{array}$ & $\begin{array}{l}\mathrm{C} \zeta \\
\mathrm{B} 8\end{array}$ & Total & Observaçōes \\
\hline 1 & 0 & 0 & 2 & 0 & 0 & 0 & 0 & 0 & 2 & $\begin{array}{l}\text { Criança B5 comenta que tem } \\
\text { familias que tem apenas pai e } \\
\text { filho e outras apenas mãe e filho }\end{array}$ \\
\hline 2 & 0 & 0 & 1 & 1 & 1 & 0 & 1 & 0 & 4 & \\
\hline 3 & 5 & 2 & 5 & 0 & 0 & 5 & 3 & 5 & 25 & \\
\hline 4 & 3 & 3 & 2 & 3 & 1 & 2 & 2 & 3 & 19 & \\
\hline 5 & 3 & 3 & 3 & 3 & 3 & 3 & 1 & 3 & 22 & \\
\hline 6 & 3 & 3 & 3 & 0 & 3 & 3 & 1 & 3 & 19 & \\
\hline 7 & 3 & 0 & 3 & 0 & 3 & 3 & 3 & 1 & 16 & \\
\hline 8 & 0 & 0 & 0 & 0 & 0 & 0 & 0 & 0 & 0 & \\
\hline 9 & - & - & - & - & - & - & - & - & - & Não se aplicou \\
\hline Total & 17 & 11 & 19 & 7 & 11 & 16 & 11 & 15 & & \\
\hline
\end{tabular}


Apresentação dos dados individuais da coleta de dados na representação lúdica do grupo BC, turma C.

\begin{tabular}{|c|c|c|c|c|c|c|c|c|c|c|c|c|}
\hline $\begin{array}{l}\text { Cç/sit } \\
\text { prob }\end{array}$ & $\begin{array}{l}\text { Ç̧ } \\
\text { C1 }\end{array}$ & $\begin{array}{l}\mathrm{C}_{\zeta} \\
\mathrm{C} 2\end{array}$ & $\begin{array}{l}\mathrm{C}_{\mathrm{G}} \\
\mathrm{C3}\end{array}$ & $\begin{array}{l}\mathrm{C}_{\mathrm{G}} \\
\mathrm{C} 4\end{array}$ & $\begin{array}{l}\mathrm{C}_{6} \\
\mathrm{C} 5\end{array}$ & $\begin{array}{l}C_{\zeta} \\
C 6\end{array}$ & $\begin{array}{l}\mathrm{C} \zeta \\
\mathrm{C} 7\end{array}$ & $\begin{array}{l}\mathrm{C}_{6} \\
\mathrm{C} 8\end{array}$ & $\begin{array}{l}\text { Cद̧ } \\
\text { C9 }\end{array}$ & $\begin{array}{l}\mathrm{Cc}_{\zeta} \\
\mathrm{C} 10\end{array}$ & Total & Observaçōes \\
\hline 1 & 0 & 0 & 0 & 0 & 0 & 1 & 0 & 0 & 0 & 0 & 1 & \\
\hline 2 & 0 & 0 & 0 & 1 & 2 & 1 & 0 & 1 & 2 & 1 & 8 & \\
\hline 3 & 0 & 0 & 0 & 0 & 2 & 3 & 3 & 4 & 0 & 2 & 14 & \\
\hline 4 & 2 & 2 & 2 & 0 & 2 & 3 & 3 & 2 & 0 & 3 & 19 & \\
\hline 5 & 0 & 0 & 2 & 0 & 0 & 3 & 3 & 0 & 2 & 3 & 13 & \\
\hline 6 & 0 & 0 & 2 & 0 & 0 & 3 & 3 & 0 & 2 & 3 & 13 & \\
\hline 7 & 0 & 1 & 0 & 1 & 1 & 0 & 1 & 0 & 3 & 0 & 7 & \\
\hline 8 & 0 & 0 & 0 & 0 & 0 & 1 & 1 & 0 & 3 & 0 & 5 & \\
\hline 9 & - & - & - & - & - & - & - & - & - & - & - & Não se aplicou \\
\hline Total & 2 & 3 & 6 & 2 & 7 & 15 & 14 & 7 & 12 & 12 & & \\
\hline
\end{tabular}

